\title{
A review of the Neotropical genus Diochus ERICHSON, 1840 (Coleoptera: Staphylinidae: Staphylininae)
}

With 48 figures and 3 keys

\author{
ULRICH IRMLER ${ }^{1}$
}

\begin{abstract}
${ }^{1}$ Institute for Ecosystem Research, Dept. Applied Ecology, University of Kiel, Olshausenstrasse 40, 24098 Kiel, Germany. -uirmler@ ecology.uni-kiel.de
\end{abstract}

Published on 2017-06-30

DOI: $110.21248 /$ contrib.entomol.67.1.001-062'

\begin{abstract}
The Neotropical species of the genus Diochus are reviewed. Two species are synonymised: D. flavicans SHARP, 1876 =D. vicinus Sharp, 1876 and D. vilis Sharp, $1885=$ D. schaumii KraAtZ, 1860. Six species groups are differentiated containing the following species: D. longicornis-group with the species D. adisi spec.nov., D. ashei spec. nov., D. guianensis spec. nov., D. longicornis Sharp, 1876, D. tarsalis Sharp, 1876, and D. unicolor spec. nov.; D. inornatusgroup with the species $D$. antennalis CAMERoN, 1922, D. amazonensis spec. nov., D. hanagarthi spec. nov., D. hermani spec. nov., D. hibbsi spec. nov., D. inornatus Sharp, 1885, D. newtoni spec. nov., D. novus spec. nov., D. plaumanni spec. nov., D. schuelkei spec. nov., D. tricolor spec. nov., and D. vicinus SHARp, 1876; D. maculicollis-group with the species: D. brooksi spec. nov., D. ecuadoriensis spec. nov., D. maculicollis Fauvel, 1891, D. mexicanus spec. nov., D. panamaensis spec. nov., D. peruvianus spec. nov., and D. pumilio Bernhauer, 1929; D. schaumii-group with the species D. angustiformis spec. nov., D. argentinus spec. nov., D. brunneus spec. nov., D. curtipennis spec. nov., and D. schaumii KrAATZ, 1860; D. verhaaghi-group with the two species D. verhaaghi spec. nov. and D. santacatarinae spec. nov.; D. nanus-group with the species D. apicipennis CAMEron, 1922, D. nanus Erichson, 1839, D. parvulus KraAtz, 1860, and D. perplexus Cameron, 1922. D. formicetorum Bernhauer, 1927 is with unclear position among the named groups. A key to the species groups and to species is provided. The relation among groups, the ecology, and the geographic distribution is discussed.
\end{abstract}

\section{Nomenclatural acts}

Diochus adisi spec. nov. - "urn:Isid:zoobank.org:act:33DAA72A-B7E0-4806-BD59-8FC17FE1EF58'

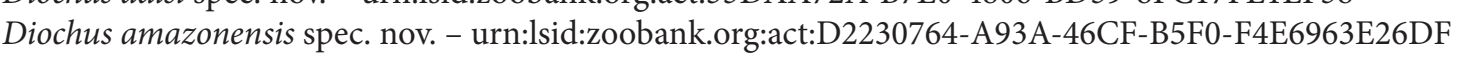

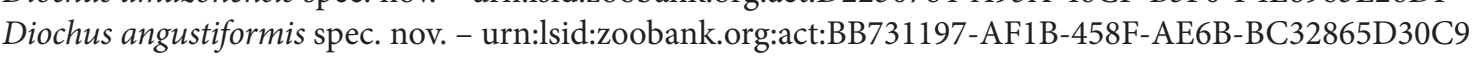

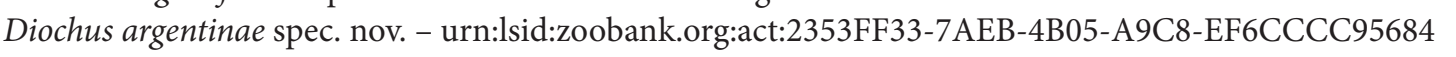

Diochus ashei spec. nov. - urn:lsid:zoobank.org:act:949EFF27-4323-46C9-8F5D-F4731958CA14

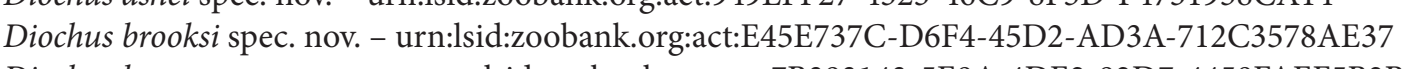

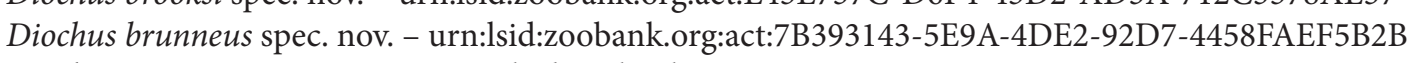

Diochus curtipennis spec. nov. - urn.1sid.zoobank.org:act:936420A-

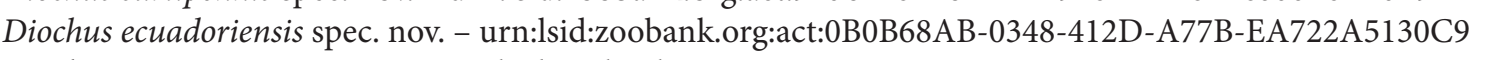

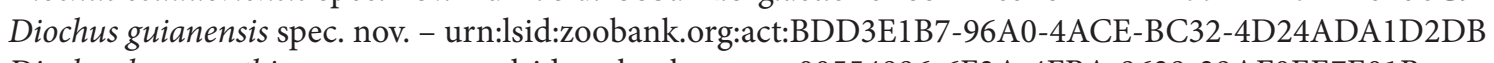

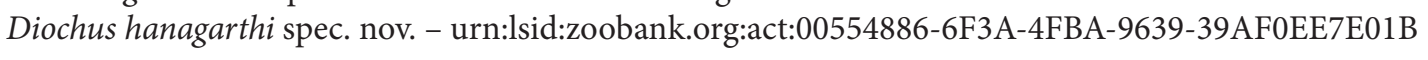




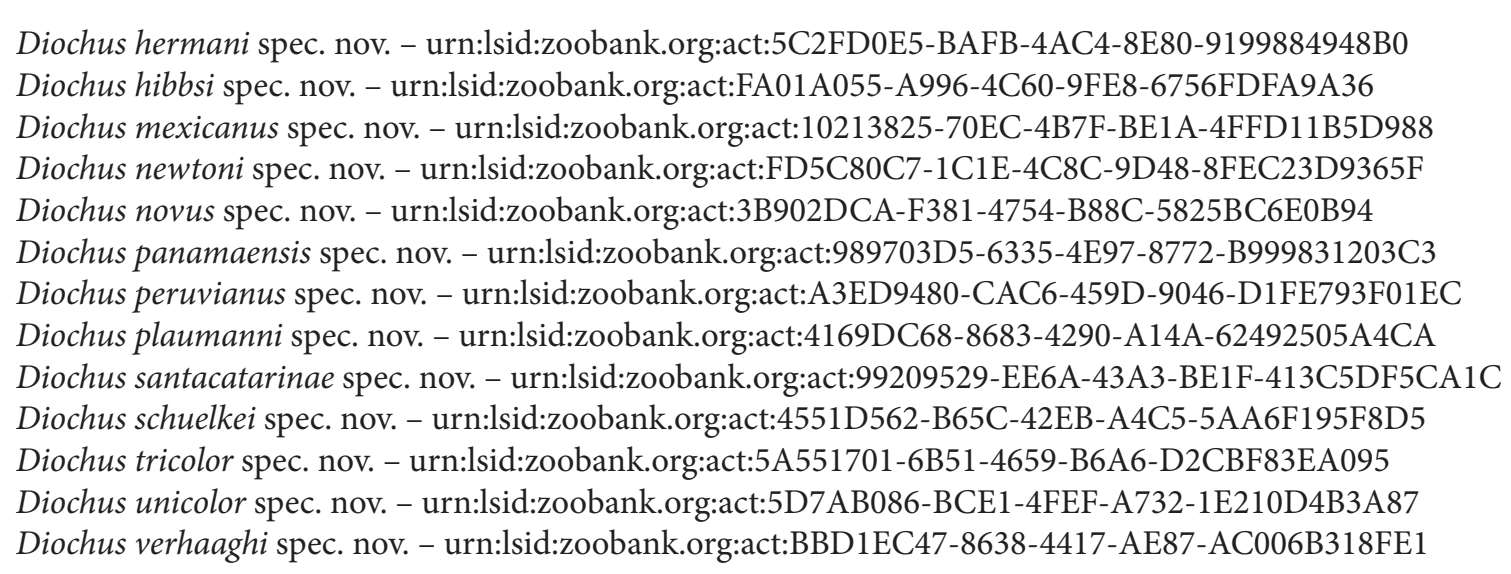

\section{Key words}

Staphylinidae, Staphylininae, Diochini, new species, Neotropics, zoogeography

\section{Zusammenfassung}

Die neotropischen Arten der Gattung Diochus wurden bearbeitet. Zwei Arten wurden synonymisiert: Diochus flavicans Sharp, $1876=$ D. vicinus Sharp, 1876 und D. vilis Sharp, $1885=$ D. schaumii KraAtz, 1860. Sechs Artengruppen wurden unterschieden, die folgende Arten enthalten: D. longicornis-Guppe mit den Arten D. adisi spec. nov., D. ashei spec. nov., D. guianensis spec. nov., D. longicornis Sharp, 1876, D. tarsalis Sharp, 1876 und D. unicolor spec. nov.; D. inornatus-Gruppe mit den Arten D. antennalis Cameron, 1922, D. amazonensis spec. nov., $D$. hanagarthi spec. nov., $D$. hermani spec. nov., $D$. hibbsi spec. nov., $D$. inornatus SHARP, 1885 , D. newtoni spec. nov., $D$. novus spec. nov., D. plaumanni spec. nov., $D$. schuelkei spec. nov., $D$. tricolor spec. nov. und $D$. vicinus SHARP, 1876; D. maculicollis-Gruppe mit den Arten: D. brooksi spec. nov., D. ecuadoriensis spec. nov., D. maculicollis Fauvel, 1891, D. mexicanus spec. nov., D. panamaensis spec. nov., D. peruvianus spec. nov. und D. pumilio Bernhauer, 1929; D. schaumii-Gruppe mit den Arten D. angustiformis spec. nov., D. argentinus spec. nov., D. brunneus spec. nov., D. curtipennis spec. nov. und D. schaumii KraATz, 1860; D. verhaaghi-Gruppe mit den zwei Arten D. verhaaghi spec. nov. und D. santacatarinae spec. nov.; D. nanus-Gruppe mit den Arten D. apicipennis Cameron, 1922, D. nanus Erichson, 1839, D. parvulus Krattz, 1860 und D. perplexus Cameron, 1922. Die Stellung von D. formicetorum Bernhauer, 1927 zu einer der Gruppen ist ungewiss, da nur Weibchen vorhanden sind. Schlüssel zur Bestimmung der Gruppen und Arten werden vorgestellt sowie die geographische Verbreitung der Arten diskutiert.

\section{Introduction}

The genus Diochus is distributed world-wide. It occurs mainly in tropical countries, but also in southern parts of the Nearctic and Palaearctic regions. According to Herman (2001) a total 38 valid species have been described. However, only three species were listed as valid species from the Neotropics, Diochus nanus Erichson, 1839, D. schaumii KraAtz, 1860, and D. fomicetorum Bernhauer, 1927, although 15 species had been described. Nearly all Neotropical Diochus species were synoymised by BLACKWELDER (1944) to Diochus nanus, although several species are clearly different from Diochus nanus by the length of antennae and are mostly distinct species. Nevertheless, the species are extremely similar in their habitus, which becomes evident by the fact that Bernhauer wrongly identified a large number of specimens.

The genus Diochus is part of the tribe Diochini, which is only represented among the subfamily Staphylininae by two additional genera: one from Chile and southern Argentina and another from Southeast Asia. The genus Diochus appears to be old, according to Chatzimanolis \& ENGEL (2011), it already occurred in the Baltic amber, which is at least 40 million years old and which is characterised by a subtropical to tropical climate (PoINAR 1992). Thus, the genus had a wider distribution during the warmer Eocene and retreated from northern regions with decreasing temperature.

The present study only concerns the Neotropical species of the genus. Among the 15 species described from the region, two were synonymised, but all others were found to be valid species. In addition, to the 13 valid species aready described, 24 new species are described here. The present study aims to describe the new species, to provide a key to all Neotropical species and to discuss their ecology and distribution as well as their potential number of species in the region. 


\section{Material, methods and morphological aspects}

The material studied in this investigation is presently deposited in the following public museums and private collections:

\section{AMNH American Museum of Natural History, New} York, USA

BMNH The Natural History Museum, London, United Kingdom

FMNH Field Museum of Natural History, Chicago, U.S.A.

INPA Collection of the Instituto de Pescisas das Amazônia, Manaus, Brazil

IRSNB Institut Royal des Sciences Naturelles de Belgique, Brussels, Belgium

KNHM University of Kansas, Museum of Natural History, Lawrence, Kansas, U.S.A.

NMW Naturhistorisches Museum Wien, Wien, Austria

SDEI Senckenberg Deutsches Entomologisches Institut, Müncheberg, Germany

ZMHU Zoologisches Museum der Humboldt-Universität, Berlin, Germany

UFMT Coleção entomologica Universidade do Curitiba, Curitiba, Paraná

MSC private collection of Manfred Schülke, Berlin, Germany, deposited in ZMHU

TSC private collection of Tim Struyve, Mechelen, Belgium

UIC private collection of author, Plön, Germany

VAC private collection of Volker Assing, Hannover, Germany

The photographs were taken using a Makroskop M 420 (Wild, Herbrugg) in combination with a digital camera Leica EC3. CombineZ5 (Hadley 2006) was used to optimise depth of focus. Length was measured in the middle of tagmata: head from clypeus to posterior edge, pronotum from anterior to posterior edge along midline, elytra from anterior edge at shoulders to posterior edge; width at the widest part of tagmata (head width includes eyes). In the measurement of total length, the abdominal intersegmental space is subtracted. The following additional measurements were made: (1) eye length (EL) and total head length (HL) to indicate the relative length of eyes abbreviated as EL : HL ratio (Fig. 1A); (2) width of head at posterior angles of head (PW) and width of head at anterior edge of eyes (EW) to indicate the divergence of head abbreviated as PW : EW ratio (Fig. 1A).

The structure of the aedeagus and of the spematheca are either specific for species or for species groups. The total copulatory organs of the male are divided into the aedeagus, the funnel-like testicles and the duct combining both organs (Fig. 1B) (see also SMEtAnA 1977). The endophallus can be separated in: (1) the thick and oval seminal vesical, which seems to serve as storage and pump for the sperms during the copulation; the relative length and width differs between species; it combines the testicles via the outer duct; (2) the basal inner duct and (3) the apical duct; the basal inner duct is thicker and forms a loop, which is ejected during the copulation (Fig. 1D); in the D. inornatus-group, the basal inner duct is widened to a funnel-like organ with apical sclerotised forceps (Fig. 1E); the apical duct is developed in the groups of the $\mathrm{D}$. longicornis-group and the D. inornatus-group; it is coiled and has several coils in the first group (Fig. 1C) and only one coil in the second group (Fig. 1E). The shape of the parameres is specific, in particular at the apex. The apex is specifically curved or widened and bears two to four differently long setae at its apical margin.

The spermatheca seems to be not species specific, but is similar within species groups. It is divided into a coiled duct and a bursa copulatrix, which is shaped like a boomerang (Fig. 1F). The bursa copulatrix can be placed either within or outside the coiled duct. Length and width of the spermatheca refers to the shape of the coiled duct, which can be oval or circular.

\section{Acknowledgements}

I thank the curators of the museums, institutions and private collectors for the steady support, help and relinquishment of several specimens for my collection: Lee Herman (AMNH), Crystal Maier (FMNH), Roger Booth (BMNH), Didier Drugmand (IRSB), Zack Falin (KNHM), Harald Schillhammer (NMW), Stephan Blank (SDEI), Johannes Frisch (ZMHU), Manfred Schülke (Berlin, Germany), Tim Struyve (Mechelen, Belgium), Volker Assing (Hannover, Germany), Manfred Verhaagh (Karlsruhe, Germany).

\section{Description of species}

\section{Species groups}

\section{Diochus longicornis-group}

\section{Diochus adisi spec. nov.

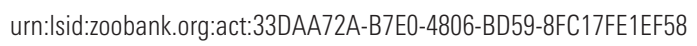 \\ Figs $4 \mathrm{~A}-\mathrm{C}, 41 \mathrm{C}$}

Type material: male, Holotype: Brazil, Amazonas, Ilha Marchanteria $\left(3^{\circ} 15^{\prime} \mathrm{S}, 59^{\circ} 58^{\prime} \mathrm{W}\right)$, Várzea, 20.1.1982, leg. J. Adis (INPA).

Paratypes: Brazil: Goias, $3 \mathrm{~km}$ S of Barra Tapirapé, forest floor, sifted, male, 9.1.1963, leg. B. Malkin (FMNH).

Diagnosis: The species must be placed into the D. longicornis group, because the endophallus has a long apical duct with several coils. It resembles $D$. ashei and D. unicolor in size. It can be distinguished from $D$. ashei 


\section{Key to species groups}

1 Endophallus of aedeagus with apical coiled duct, bursa copulatrix within the coiled duct of spematheca (Figs 2-19)

- Endophallus of aedeagus without apical coiled duct, bursa copulatrix mostly outside the coiled duct of spermatheca (Figs 20-37)

2 Apical coiled duct of endophallus with several coils, aedeagus mostly laterally depressed (Figs 2-7)

D. longicornis-group

- Apical coiled duct of endophallus with one short coil, aedeagus not laterally depressed (Figs 8-19)

D. inornatus-group

3 Parameres small with slightly angled apex and four short setae, aedeagus with long apical hooks (Figs 32, 33).. D. verhaaghi-group

- Parameres curved in apical half or with widened apex and with two or three setae (Figs 20-31, Figs 34-37) ...... 4

4 Parameres curved in its apical half (Figs 20-26)

D. maculicollis-group

- Parameres widened at apex (Figs 27-31, Figs 34-37) 5

5 Widening at apex of parameres approximately symmetric and mostly with emarginate apical margin, small species with short antennae, penultimate antennomeres much wider than long (Figs 34-37) D. nanus-group

- Widening at apex of parameres assymmetric, larger species with longer antennae, antennomeres 4 and 5 longer than wide or quadrate (Figs 28-31) D. schaumii-group

by the unicoloured body and by the larger eyes. Temples are nearly twice as long as eyes in D. ashei, whereas temples of $D$. adisi are 1.6 times as long as eyes. The colouration of $D$. adisi resembles that of D. unicolor, but the eyes of $D$. unicolor are still shorter with temples 2.6 times as long as eyes. Moreover, the straight shape of the parameres is similar to that of D. unicolor. In $D$. adisi the shaft has few sensillae, whereas no sensillae are found in the paramere of D. unicolor. The female of D. adisi is unknown.

Description: Length $2.8 \mathrm{~mm}$. Colouration: unicoloured yellow.

Head $0.44 \mathrm{~mm}$ long, $0.36 \mathrm{~mm}$ wide; eyes large, slightly prominent; EL : HL 0.27; temples 1.6 times as long as eyes; sides very slightly divergent to posterior angles; PW : EW 1.13; posterior angles rounded; posterior margin slightly rounded; wide midline impunctate; adjacent to midline with row of six setiferous punctures; in supraocular position with second longitudinal line of four to six setiferous punctures; postocular area with denser setiferous punctures; without microsculpture; surface polished.

Antennae nearly as long as head and pronotum combined; antennomeres one to three elongate; first antennomere slightly thicker than following antennomeres; second and third antennomere conical; twice as long as apical width; length of following antennomeres decreasing; fourth antennomere 1.2 times as long as wide; tenth antennomere slightly wider than long; all antennomeres pubescent and with few short apical setae.
Pronotum $0.52 \mathrm{~mm}$ long, $0.41 \mathrm{~mm}$ wide; widest in anterior half; narrowed to anterior margin in wide convex curve; posterior half slightly convergent; posterior angles widely rounded; posterior margin straight; lateral margin fine; in dorsal aspect, visible in posterior half; row of three to four setiferous punctures in convex longitudinal line; interstices between posterior pair of punctures 2.2 times as wide as interstice between anterior pair of punctures; two central pairs of setiferous punctures in posterior half; along lateral margin more setiferous punctures; without microsculpture; surface polished.

Elytra $0.53 \mathrm{~mm}$ long, $0.56 \mathrm{~mm}$ wide; sides slightly divergent to posterior angles; nearly parallel; at posterior margin 1.2 times as wide as at shoulders; shoulders rounded; posterior margin slightly triangularly emarginate; setiferous punctation in irregular rows of four to six punctures; weak coriaceous ground sculpture; surface less shiny than head and pronotum.

Abdomen densely pubescent.

Aedeagus moderately slender; seminal vesical one third as long as total length of central lobe; thick, nearly globular; seminal duct looped; ending anteriad in funnel-like sclerotised forceps; apical duct with two large coils.

Etymology: The species name honours Joachim Adis, who collected this interesting species in the Central Amazon. 
Diochus ashei spec. nov.

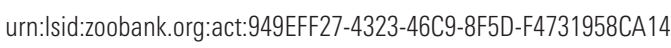

Figs $6 \mathrm{~A}-\mathrm{C}, 38 \mathrm{C}, 41 \mathrm{D}$

Type material: male Holotype: Peru: Tambopata Prov., Madre de Dios Dpto., $15 \mathrm{~km}$ NE Puerto Maldonado, Reserva Cuzco Amazónico (69 $\left.03^{\circ} \mathrm{W}, 12^{\circ} 33^{\prime} \mathrm{S}\right), 200 \mathrm{~m}$ elevation, Plot \#Z1U19, collected by flight intercept trap, 13.7.1989, leg. J.S. Ashe \& R.A. Leschen, \#484, (KNHM).

Paratypes: 1 female, 1 male, with same data as holotype (KNHM, UIC).

Diagnosis: According to the aedeagal structure, the species is related to D. longicornis SHARP, 1876. Regarding the small size, it resembles $D$. unicolor and $D$. adisi. It can be distinguished from $D$. unicolor by the larger eyes. In this respect, it resembles $D$. adisi. Differentiation to $D$. adisi are listed there. D. ashei also resembles $D$. tricolor by the light yellow pronotum and the darker head and elytra. Beside the differences in the aedeagus, the punctation of the head is denser in D. tricolor than in $D$. ashei. Whereas in $D$. tricolor the clypeus is densely punctate, it is impunctate in $D$. ashei. The females of both species are distinguished also by the shape of the spermatheca that has irregular coils in $D$. tricolor, but circle coils in $D$. ashei.

Description: Length: $3.0 \mathrm{~mm}$. Colouration: light brown; fifth and sixth abdominal segment slightly darker; elytra light brown; head dark brown; pronotum light yellow; legs and antennae yellow.

Head $0.41 \mathrm{~mm}$ long, $0.35 \mathrm{~mm}$ wide; eyes slightly prominent; EL : $\mathrm{HL}=0.29$; temples 1.9 times as long as eyes; slightly divergent to posterior angles; PW : EW 1.33; posterior angles shortly rounded to straight posterior margin; neck extremely narrow; 0.25 times as wide as width at posterior angles; setiferous punctation sparse; adjacent to wide impunctate midline with row of four punctures and second irregular supraocular row of punctures; temples with denser punctation; microsculpture weak and indistinct; on clypeus approximately isodiametric; on vertex transversely striate; surface slightly shiny.

Antennae nearly as long as head and pronotum combined; first antennomere thicker and longer than following antennomeres; elongate second and third antennomere conical and 1.8 times as long as apical width; length of following antennomeres decreasing; fourth antennomere slightly longer than wide; tenth antennomere 1.5 times as wide as long; all antennomeres pubescent and with few apical setae.

Pronotum $0.51 \mathrm{~mm}$ wide, $0.37 \mathrm{~mm}$ wide; sides widest in anterior third; strongly narrowed to neck; slightly narrowed to posterior angles; posterior angles widely rounded; lateral margin fine; in dorsal aspect, visible in posterior half; setiferous punctation sparse; along wide impunctate midline with row of three pairs of punctures; interstice between first pair of punctures nearly twice as wide as between two posterior pairs; few additional punctures laterad; several setiferous punctures along lateral margin; without microsculpture; surface polished; with sparse micro-punctation.

Elytra $0.50 \mathrm{~mm}$ long, $0.54 \mathrm{~mm}$ wide; sides divergent to posterior angles; at posterior angles 1.3 times as wide as at shoulders; shoulders obtuse; posterior margin slightly triangularly emarginate; setiferous punctation in irregular rows of four to five punctures; weakly coriaceous ground sculpture; surface less shiny than head and pronotum.

Abdomen densely pubescent.

Aedeagus with thick, nearly globular seminal vesical; 0.4 times as long as central lobe; basal inner duct looped; apical duct with two large coils; paramere shorter than central lobe; not widened at apex; slightly curved and with three setae shortly in front of apex; two long setae and one slightly shorter seta.

Spermatheca globular, $0.15 \mathrm{~mm}$ diameter, bursa copulatrix in central position to coiled duct; coiled duct with few coils.

Etymology: The species name honours J.S. Ashe, one of the collectors, who extensively collected and worked on Neotropical rove beetles and passed to early.

\section{Diochus guianensis spec. nov.

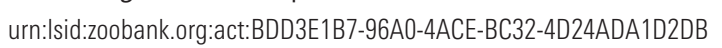 Figs $5 \mathrm{~A}-\mathrm{C}, 38 \mathrm{D}, 41 \mathrm{E}$}

Type material: male Holotype: French Guiana, Saül, $7 \mathrm{~km} \mathrm{~N}, 3 \mathrm{~km}$ NW Les Eaux Claire, Mt. La Fumée $\left(3^{\circ} 39.46^{\prime} \mathrm{N}, 53^{\circ} 13.19^{\prime} \mathrm{W}\right)$, collected by flight intercept trap, 1.-8.6.1997, leg. J. Ashe, R. Brooks \#FG1AB97 162 (KNHM).

Paratypes: 1 male, 1 female with same data as holotype (1 KNHM, 1 UIC); Roura, $39.4 \mathrm{~km}$ SSE $\left(4^{\circ} 32.43^{\prime} \mathrm{N}\right.$, $\left.52^{\circ} 8.26^{\prime} \mathrm{W}\right), 270 \mathrm{~m}$ elevation, collected by flight intercept trap, 3 males, 3 females, 29.5.-10.6.1997, leg. J. Ashe, R. Brooks \#FG1AB97 172 (KNHM); same location and collectors, 3 females, 25.-29.5.1997, \#FG1AB97 076 (2 KHNM, 1 UIC).

Diagnosis: Regarding the size, D. guianensis resembles $D$. longicornis and $D$. tarsalis of this group. The male can be easily separated by the short nearly globular seminal vesical. In contrast to D. guianensis, the seminal vesicals are elongate in D. longicornis and D. tarsalis. Moreover, the antennae are much shorter in D. guianensis than in those species.

Description: Length: $4.4 \mathrm{~mm}$. Colouration: dark brown to black; at anterior half of pronotum indistinctly lighter brown; legs and antennae light brown.

Head: $0.59 \mathrm{~mm}$ long, $0.49 \mathrm{~mm}$ wide; eyes not prominent; $\mathrm{EL}: \mathrm{HL}=0.25$; temples 2.5 times as long as eyes; temples slightly divergent to posterior angles; $\mathrm{PW}$ : $\mathrm{EW}=1.19$; 
posterior angles widely rounded to convex posterior margin; setiferous punctation sparse and moderately deep; wide midline impunctate; on vertex, adjacent to midline three pairs of punctures; interstice between anterior pair slightly shorter than between posterior pairs; additional supraocular row of three to five punctures; postocular area with several punctures; very weak transversely striate microsculpture on clypeus and anterior vertex; surface shiny.

Antennae slightly longer than head and half of pronotum combined; first antennomere thicker and longer than following antennomeres; 2.5 times as long as wide; second and third antennomere conical; twice as long as apical width; following antennomeres decreasing in length; fourth antennomere one third longer than wide; tenth antennomere one third wider than long; all antennomeres pubescent and with several apical setae.

Pronotum $0.72 \mathrm{~mm}$ long, $0.55 \mathrm{~mm}$ wide; sides nearly parallel; anterior angles widely rounded to evenly convex anterior margin; posterior angles shortly rounded to convex posterior margin; lateral margin fine; in dorsal aspect, visible in posterior half; setiferous punctation sparse and moderately deep; adjacent to wide impunctate midline with three pairs of punctures; interstice between anterior pair 2.5 times as wide as between posterior pairs; few setiferous punctures laterad; several setiferous punctures along lateral margin; without microsculpture; with sparse micro-punctation; surface polished.

Elytra: $0.69 \mathrm{~mm}$ long, $0.72 \mathrm{~mm}$ wide; sides slightly divergent to posterior angles; shoulders obtuse; posterior angles nearly rectangular; posterior margin slightly concave; setiferous punctation in irregular rows of five to six punctures; ground sculpture weakly coriaceous; surface less shiny than that of head and pronotum.

Abdomen densely pubescent.

Aedeagus narrow in dorsal aspect; in lateral aspect broad; seminal vesical thick; oval; 0.45 times as long as total length of central lobe; basal inner duct looped; apical duct flagellate with three wide coils; paramere slender; curved in apical third to acute apex; at outer angle with three setae; in basal part of shaft with several sensillae.

Spermatheca $0.47 \mathrm{~mm}$ long, $0.21 \mathrm{~mm}$ wide; bursa copulatrix in central position of shoe-like shaped coiled duct.

Etymology: The species name derived from the country, where the holotype was collected by J. Ashe and R. Brooks.

\section{Diochus longicornis SHARP, 1876 \\ Figs 2A-C, 38A, 41A}

Diochus longicornis SHARP, 1876: 184

Type material examined: male, Syntype, Brazil: Pará, Tapajos, (BMNH).
Further material examined: Mexico: San Luis Potosi, Sierra de la Abra, Sotano de la Tinaja, flood debris on mud slope, $1500 \mathrm{ft}$. from entrance; 1 male, 1 female, 18.2.1970, leg. J.A.L. Cooke (AMNH); same location, $11 \mathrm{~km}$ NE Ciudad Valles, cave, debris, Berlese, 2 males, 4 females, 4.7.1970, leg. J. Cooke, 1 male, 2 females, 20.2.1973, leg. S. Willey (7 AMNH, 2 UIC); same location, La Cueva de la Tinaja, $10.5 \mathrm{~km}$ NE Cd. Valles, cave, female, 20.2.1973, leg. T.R. Mollhagen (AMNH); Belize: Orange Walk Distr., Rio Bravo Conserv. Area, rd. to Archaelogical site $\left(17^{\circ} 50.56^{\prime} \mathrm{N}, 89^{\circ} 02.34^{\prime} \mathrm{W}\right)$, flight intercept trap \#2, female, 25.4.-5.5.1996, leg. C. Carlton \#102 (KNHM); Costa Rica: Vara Blanca, zwischen Barba \& Poas, $2000 \mathrm{~m}$ elev., female, leg. H. Schmidt (FMNH); Finca Castilla, male, 6.1938, leg. A. Bierig (FMNH); Cuba: Aspiro, 1 male, 6.8.1933, leg. A. Bierig (FMNH); Rangel, 3 females, 6.4.1930, leg. A. Bierig (FMNH); Panama: Colon, $15 \mathrm{~km} \mathrm{~N}$ jct. Escobal \& Piña Rds. Ca. $30 \mathrm{~m}$ elevation, collected by flight intercept trap, male, 2.-11. Jun.1996, leg. J. Ashe \& R. Brooks, \#PAN1AB96 121 (KNHM); Bocas del Toro Prov., Almirante, forest floor litter, female, 1.4.1959, leg. H.S. Dybas (FMNH); French Guiana: Caussade $\left(52^{\circ} 57^{\prime} \mathrm{W}, 5^{\circ} 10^{\prime} \mathrm{N}\right)$, car net, 1 male, 3 females, 7.11.2011, leg. T. Struyve (2 TSC, 2 UIC); Coralie $\left(52^{\circ} 21^{\prime} \mathrm{W}, 4^{\circ} 30^{\prime} \mathrm{N}\right)$, car net, 2 females, 7.11.2011, leg. T. Struyve (TSC); Colombia: Putumayo, PNN La Playa Rio Vega ( $\left.74^{\circ} 56^{\prime} \mathrm{W}, 0^{\circ} 07^{\prime} \mathrm{S}\right), 320 \mathrm{~m}$ elevation, Malaise trap, 1 female, 15.-30.10.2001, leg. R. Cobete \#2437 (KNHM); Putumayo, PNN La Playa, Cabaña Viviano Concha ( $\left.74^{\circ} 56^{\prime} \mathrm{W}, 0^{\circ} 07^{\prime} \mathrm{S}\right), 320 \mathrm{~m}$ elevation, Malaise trap, 1 male, 15.-30.10.2001, leg. R. Cobete \#M2438 (UIC); Vichada, PNN El Tuparro Cerro Tomás $\left(67^{\circ} 51^{\prime} \mathrm{W}\right.$, $\left.5^{\circ} 21^{\prime} \mathrm{N}\right), 140 \mathrm{~m}$ elevation, Malaise trap, 1 female, 22.5.3.6.2001, leg. I. Gil \#1789 (KNHM); Venezuela: Zulia Distrito, Municipio Perija Libertad, El Tarra, $100 \mathrm{~km} \mathrm{~S}$ of, at light, female, 7.1982, leg. V. Linares (FMNH); same region, $15 \mathrm{~km} \mathrm{~W}$ of Machiques, at light, 1 male, 1 female, 6.1982, leg. V. Linares (FMNH); same region, Hacienda Aponcito, $35 \mathrm{~km} \mathrm{~W} \mathrm{Manchiques,} \mathrm{at} \mathrm{light,} \mathrm{male,} \mathrm{7.1982,}$ leg. V. Linares (FMNH); same region, El Amparo, at light, female, 6.1982, leg. V. Linares (FMNH); same region, Rancho Calvario, NW Manchiques, at light, 1 male, 1 female, 7.1982, leg. V. Linares (FMNH); Ecuador: Sucumbios, Sacha Lodge $\left(76^{\circ} 5^{\prime} \mathrm{W}, 0^{\circ} 5^{\prime} \mathrm{S}\right), 270 \mathrm{~m}$ elevation, Malaise trap, 1 male, 4.-14.3.1994, 1 male, 1 female, 14.-24.3.1994, leg. Hibbs (2 KNHM, 1 UIC); Peru: Madre de Dios Dept., Tambopata, 3 males, 5 females, litter at swamp edge, 2 males, 3 females, rotten figs, 28.10.1982, leg. L.E. Watrous \& G. Matzurek (FMNH, UIC); Bolivia: El Beni, Beni Stn. Palm Camp, NE of San Borja, collected at lights, BIOLAT-SI/MAB, 1 male, 1.8.1988, leg. W. Brooks (KNHM); Beni, Ilha Flores, Rio Iténez, 1 male, 2 females, 7.8.1964, leg. J.K. Bouseman \& L. Lussenhop (AMNH); Beni Prov., Chacobo Indian village, on Rio Benicito $\left(66^{\circ} 0^{\prime} \mathrm{W}, 12^{\circ} 20^{\prime} \mathrm{S}\right)$, male, 26.7.-4.8.1960, leg. B. Malkin (FMNH); Dept. Beni, Prov. Vac Diez, $2 \mathrm{~km}$ NW Tumichucua, leaf litter in sunken aera, 2 females, 12.8.1990, leg. P. Parillo (FMNH); same 
region, Isla Motacu, forest leaf litter, female, 16.8.1990, leg. P. Parillo \& P. Bettella (FMNH); Brazil: Amazonas without further data, male, Sharp coll. (FMNH, excgange with BMNH); Amazonas, PNN Amacayacu Matamata $\left(70^{\circ} 15^{\prime} \mathrm{W}, 3^{\circ} 41^{\prime} \mathrm{S}\right), 150 \mathrm{~m}$ elevation, Malaise trap, 1 female, 8.-14.8.2000, leg. A. Parente \#M689 (KNHM); Choco, PNN Los Katios, Centro Adiministrativo Sautatá, Dentro del Bosque $\left(77^{\circ} 8^{\prime} \mathrm{W}, 7^{\circ} 51^{\prime} \mathrm{N}\right), 30 \mathrm{~m}$ elevation, Malaise trap, 1 male, 13.-29.6.2003, leg. P. López \#3764 (KNHM); Norte de Santander, ANU Los Estoraques Qda., La Media $\left(8^{\circ} 13^{\prime} \mathrm{N}, 73^{\circ} 14^{\prime} \mathrm{W}\right), 1480 \mathrm{~m}$ elevation, collected by Malaise trap, female, 15.9.-1.10.2003, leg. J. Vegas \#M4046 (KNM); Santa Catarina, Linha Facão, 1 female, May. 1954, leg. F. Plaumann (KNHM); Nova Teutonia (52 $\left.23^{\prime} \mathrm{W}, 27^{\circ} 11^{\prime} \mathrm{S}\right), 300-500 \mathrm{~m}$ elev., female, 3.1954, 2 females, 10.-12.1952, leg. F. Plaumann (FMNH); same location, 3 females, coll. A. Bierig (FMNH); Gioas, Sta. Isabel, R. Araguaia, Isla Bananal, at light, male, 27.10.4.11.1960, leg. B. Malkin (FMNH); Mato Grosso, Barra do Tapirapé, at light, 1 male, 3 females, 15.12.1960, leg. B. Malkin (FMNH); Mato Grosso do Sul, Corumba, 1 male, 1 female $(\mathrm{FMNH})$.

Diagnosis: Within the species group, D. longicornis resembles $D$. tarsalis in size and long antennae. Antennae are slightly longer than in $D$. tarsalis. The main difference is the shorter seminal vesical and the larger coils of the apical filament duct of the endophallus. The paramere is more slender without the apical process of $D$. tarsalis.

Description: Length: $4.9 \mathrm{~mm}$. Colouration: head dark brown; pronotum and elytra light brown; abdomen brown; only slightly darker than elytra and pronotum; antennae light brown with three basal antennomeres slightly lighter than following antennomeres; legs yellowish brown.

Head: $0.65 \mathrm{~mm}$ long, $0.51 \mathrm{~mm}$ wide; eyes not prominent; approximately half as long as temples; $\mathrm{EL}: \mathrm{HL}=0.28$; temples slightly divergent to posterior angles; $\mathrm{PW}: \mathrm{EW}=1.14$; posterior angles widely rounded to narrow neck; neck approximately one fourth as wide as head; setiferous punctation moderately deep and dense; on average, interstices between punctures 2.5 times as wide as diameter of punctures; with wide impunctate midline; without microsculpture; surface shiny.

Antennae as long as head and pronotum combined; conical first antennomere at apex slightly thicker than following antennomeres; 1.5 times as long as wide; second antennomere as long as first, but more or less parallel; third antennomere slightly longer than second; following antennomeres decreasing in length; fourth antennomere distinctly shorter than third; penultimate antennomere only half as long as third, but still one third longer than wide; last antennomere again slightly longer than penultimate antennomere; all antennomeres with few long apical setae and sparsely pubescent.

Pronotum: $0.74 \mathrm{~mm}$ long, $0.62 \mathrm{~mm}$ wide; widest at middle; slightly narrowed to anterior and posterior angles in smooth curve; anterior and posterior angles widely rounded without distinct angles; lateral margin fine; in dorsal aspect, covered in anterior half; posterior and anterior margin as fine as lateral margin; setiferous punctation sparse and weak; two pairs of punctures at central midline; large areas in front of anterior pair of punctures and laterad to pairs of punctures impunctate; on average, interstices between punctures on lateral disc at least three times as wide as diameter of punctures; without microsculpture; surface shiny.

Elytra: $0.79 \mathrm{~mm}$ long, $0.83 \mathrm{~mm}$ wide; widest at posterior angles; slightly narrowed to shoulders; shoulders obtusely rounded, but distinct; lateral punctures with long black setae; on disc, setiferous punctation in irregular longitudinal rows; fist row directly adjacent to suture line; three further lines laterally; surface with indistinct weak ground sculpture; shiny.

Abdomen densely pubescent.

Aedeagus with seminal vesical slightly shorter than half of total length of central lobe; apical inner duct with several coils; paramere exceeding central lobe; narrow; only slightly widened to apex; at obtuse apex with four long setae; no sensillae at shaft.

Spermatheca $0.46 \mathrm{~mm}$ long, $0.27 \mathrm{~mm}$ wide; bursa copulatrix in central position to coiled duct; coiled duct asymmetrically oval; at one end smaller than at other.

\section{Diochus tarsalis SHARP, 1876 \\ Figs $3 \mathrm{~A}-\mathrm{C}, 38 \mathrm{~B}, 41 \mathrm{~B}$}

\section{Diochus tarsalis SHARP, 1876: 185}

Type material examined: male, Syntype: Brazil: Pará, Tapajos (BMNH).

Further material examined: Brazil: Amazonas, Manaus, Ilha de Marchanteria $\left(59^{\circ} 58^{\prime} \mathrm{W}, 3^{\circ} 15^{\prime} \mathrm{S}\right)$, Varzéa, 2 males, 21.12.1981, 6.1.1982, leg. J. Adis (UIC); Amazonas, upper Rio Negro, Umarituba $\left(67^{\circ} 242 \mathrm{~W}, 0.046 \mathrm{~N}\right)$, female, Feb. 1994, leg. M. v. Tschirnhaus (UIC); Bolivia: Depart. Santa Cruz Espiritu, Rio Yacuma $\left(60^{\circ} 31^{\prime} \mathrm{W}, 16^{\circ} 11^{\prime} \mathrm{S}\right)$, 1 female, 1 male, 18.9.1980, leg. W. Hangarth (UIC).

Diagnosis: The species closely resembles $D$. longicornis in size and colouration. Additional to the stronger widened tarsomeres of the anterior legs, already noted by SHARP (1876), the following characters differ from those of D. longicornis: the longer seminal vesical of the endophallus and the hook-like apical process of the paramere.

Description: Length: 4.4-4.6 mm. Colouration: dark brown; pronotum slightly lighter than head; elytra still slightly lighter brown with indistinct darker areas; abdomen dark brown; legs and antennae light brown to yellowish brown; antennomeres one to three lighter than following antennomeres. 
Head: $0.60 \mathrm{~mm}$ long, $0.51 \mathrm{~mm}$ wide; eyes slightly prominent; temples more than twice as long as eyes; EL : $\mathrm{HL}=0.25$; temples slightly divergent to posterior angles; $\mathrm{PW}: \mathrm{EW}=1.17$; posterior angles widely rounded to neck; neck one third as wide as head; setiferous punctation moderately deep and dense; denser close to posterior angles than in anterior half; wide midline from clypeus to close to posterior margin impunctate; on lateral vertex, interstices between punctures twice as wide as diameter of punctures; close to neck, interstices approximately as wide as diameter of punctures; without microsculpture; surface shiny.

Antennae slightly longer than head and half of pronotum combined; first antennomere twice as long as wide; second antennomere one fourth shorter than first; third antennomere again longer; nearly twice as long as second; three times longer than wide; following antennomeres decreasing in length; fourth antennomere longer than wide; penultimate antennomere nearly quadrate; all antennomeres with short bristles at apex and densely pubescent.

Pronotum: $0.81 \mathrm{~mm}$ long, $0.64 \mathrm{~mm}$ wide; widest near middle in posterior half; sides slightly rounded and narrowed to anterior and posterior angles in smooth curve; nearly parallel at middle; posterior and anterior angles widely rounded; lateral margin fine; in dorsal aspect, only visible in posterior third; setiferous punctation large, but sparse; along impunctate midline with three punctures; on average, interstices between punctures four to five times as wide as diameter of punctures; along lateral margin with denser row of setiferous punctures; setae of punctures thick and long; without microsculpture; surface shiny.

Elytra: $0.73 \mathrm{~mm}$ long, $0.77 \mathrm{~mm}$ wide; widest at posterior angles; shoulders distinct, but obtuse; posterior margin slightly emarginate; with irregular longitudinal lines of setiferous punctures; first line adjacent to suture; disc lines more irregular; setae of punctures thick and long, in particular, along lateral margin; setae near shoulders extremely long and thick; weak and indistinct slightly coriaceous ground sculpture; without microsculpture; surface shiny.

Abdomen densely pubescent.

Aedeagus with seminal vesical slightly longer than half of central lobe; basal inner duct looped; inner apical duct coiled; paramere slightly exceeding central lobe; slightly widened at middle; more strongly widened at apex into broad triangular process; process sinuate at anterior margin; ending in short hook-like structure; at inner side with four long setae.

Spermatheca $0.42 \mathrm{~mm}$ long, $0.23 \mathrm{~mm}$ wide; bursa copulatrix in slightly asymmetric position to coiled duct; coiled oval duct asymmetric with smaller and wider half; nearly parallel at middle.
Diochus unicolor spec. nov.

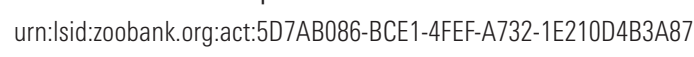

Figs $7 \mathrm{~A}-\mathrm{C}, 38 \mathrm{E}, 41 \mathrm{~F}$

Type material: male Holotype: Suriname: Para, Cardina creek, $11 \mathrm{~km}$ SE Zanderij Airport $\left(55^{\circ} 09.29^{\prime} \mathrm{W}\right.$, $\left.5^{\circ} 23.36^{\prime} \mathrm{N}\right), 30 \mathrm{~m}$ elevation, collected by flight intercept trap, 19.-20.6.199, leg. Z.H. Falin \& A. Gangadin, \#SUR1F99 088 (KNHM).

Paratypes: Panama: Canal Zone, Frijoles train stop, sifted, leaf litter, male, 25.10.1975, leg. D.S. Chandler (FMNH); Bolivia: Beni, Ilha Flores, Rio Iténez, 1 male, 3 females, 7.8.1964, leg. J.K. Bouseman \& L. Lussenhop (AMNH); Santa Cruz, $10 \mathrm{mi}$ W Puerto Chuelo, UV light trap, male, 27.3.1978, leg. Marshall (FMNH); Brazil: Goias, Sta. Isabel, R. Araguaia, Isla Bananal, at light, female, 27.10.-4.11.1960, leg. B. Malkin (FMNH); Paraguay: Paraguari, Sapucai $\left(25^{\circ} 40^{\prime} \mathrm{S}, 56^{\circ} 55^{\prime} \mathrm{W}\right), 190 \mathrm{~m}$ elevation, male, 1.-3.4.1994, leg. U. Drechsel (UIC); Dep. Central,

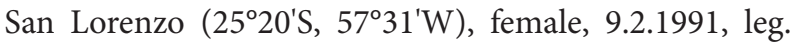
U. Drechsel (KNHM); Villarrica, female, April, 1933, leg. Koller (NMW).

Diagnosis: Regarding the small size, D. unicolor resembles D. ashei and D. adisi of this group. It is mainly separated from these two species by the shorter eyes. EL : HL is only 0.21 , wheres it is both 0.29 and 0.27 in $D$. ashei and D. adisi, respectively.

Description: Length: $3.0 \mathrm{~mm}$. Colouration: light brown to yellow; head slightly darker brown; legs and antennae light yellow.

Head $0.41 \mathrm{~mm}$ long, $0.38 \mathrm{~mm}$ wide; eyes prominent; temples 2.6 times as long as eyes; $\mathrm{EL}: \mathrm{HL}=0.21$; distinctly divergent to posterior angles; $\mathrm{PW}: \mathrm{EW}=1.22$; posterior angles shortly rounded to approximately straight posterior margin; setiferous punctation moderately dense; narrow midline impunctate; along midline, irregular row of four setiferous punctures; supraocular area with irregular setiferous punctation; temples more densely punctate; clypeus without microsculpture; surface polished; vertex with distinct transversely striate microsculpture; slightly shiny.

Antennae as long as head and pronotum combined; first antennomere thicker than following antennomeres; triangular second antennomere more than twice as long as at apical width; conical third antennomere twice as long as apical width; length of following antennomeres decreasing; fourth antennomere slightly longer than wide; tenth antennomere quadrate; all antennomeres pubescent and with apical setae.

Pronotum $0.56 \mathrm{~mm}$ long, $0.42 \mathrm{~mm}$ wide; widest in anterior half; widely rounded in nearly semi-circular curve; posteriad slightly convergent to shortly rounded posterior angles; posterior margin straight; lateral margin fine; in dorsal aspect, visible in posterior half; setiferous punctation moderately dense; along impunctate midline with three pairs of setiferous punctures; interstice 
between anterior pair of punctures three times as wide as between posterior pairs of punctures; laterad four to five setiferous punctures; along lateral margin several setiferous punctures.

Elytra $0.53 \mathrm{~mm}$ long, $0.53 \mathrm{~mm}$ wide; sides slightly divergent to posterior margin; shoulders obtusely angulate; posterior margin deeply emarginate; emargination triangular; setiferous punctation in irregular rows; inner row of five punctures adjacent to suture line; two additional rows on disc; ground sculpture weakly coriaceous; surface slightly shiny.

Abdomen densely pubescent.

Aedeagus short and broad; seminal vesical of endophallus thick and oval; approximately half as long as total length of central lobe; inner basal duct looped; continued to coiled apical duct; paramere slender; with four long apical setae; without sensillae at shaft.

Spermatheca $0.37 \mathrm{~mm}$ long, $0.24 \mathrm{~mm}$ wide; oval; bursa copulatrix approximately in central position of coiled duct.

Etymology: The species name derives from the same Latin word meaning only one colour and refers to the light brown to yellowish colouration without any distinct darker parts.

\section{Diochus inornatus-group}

\section{Diochus amazonensis spec. nov.}

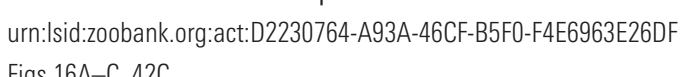

Figs $16 \mathrm{~A}-\mathrm{C}, 42 \mathrm{C}$

Type material: male, Holotype: Brazil: Amazonas, Manaus, Ilha Marchanteria $\left(59^{\circ} 58^{\prime} \mathrm{W}, 3^{\circ} 15^{\prime} \mathrm{S}\right)$, floating meadow, 4.11.1981, leg. J. Adis, \#BE50B (INPA).

Diagnosis: Within the D. inornatus-group, D. amazonensis resembles $D$. antennalis by the light yellow colouration. It is slightly larger than $D$. antennalis, the eyes are slightly longer, the head is less divergent to the posterior margin, and the antennae are distinctly longer. Moreover, the paramere is more slender than that of. D. antennalis and the apex is symmetrically widened and not asymmetric like in D. antennalis. Unfortunately, only the male holotype is known.

Description: Length: $3.5 \mathrm{~mm}$. Colouration: unicoloured yellow.

Head: $0.51 \mathrm{~mm}$ long, $0.43 \mathrm{~mm}$ wide; eyes large; slightly prominent; temples twice as long as eyes; $\mathrm{EL}: \mathrm{HL}=0.27$; sides of temples slightly divergent to posterior angles; $\mathrm{PW}: \mathrm{EW}=1.18$; posterior angles obtusely angulate; posterior margin nearly straight; setiferous punctation sparse and deep; row of six to seven punctures adjacent to wide impunctate midline; postocular area more densely punctate; microsculpture extremely weak; transversely reticulate; surface nearly polished.

Antennae as long as head and pronotum combined; first antennomere thicker than following antennomeres; one third longer than second and third antennomere; conical second antennomere thicker than third antennomere; twice as long as its apical width; conical third antennomere nearly three times longer than its apical width; length of following antennomeres decreasing; fourth antennomere twice as long as wide; seventh antennomere only slightly longer than wide; following antennomeres approximately quadrate; all antennomeres pubescent; basal antennomeres with few long setae.

Pronotum: $0.58 \mathrm{~mm}$ long, $0.45 \mathrm{~mm}$ wide; sides nearly parallel; anterior angles widely rounded; anterior margin nearly semi-circular; posterior angles obtuse; lateral margin fine; in dorsal aspect, visible in posterior two third; setiferous punctation sparse and moderately deep; adjacent to wide impunctate midline with row of three punctures; interstice between first pair of punctures one third wider than between posterior two pairs; laterad with irregular number of five to six punctures; along lateral margin with several setiferous punctures; without microsculpture; surface polished.

Elytra $0.63 \mathrm{~mm}$ long, $0.57 \mathrm{~mm}$ wide; sides slightly divergent to posterior margin; posterior margin with slightly triangular emargination; shoulders obtusely angulate; setiferous punctation in irregular rows of five to six punctures; weak ground sculpture coriaceous; surface shiny.

Abdomen densely pubescent.

Aedeagus broad and stout; seminal vesical of endophallus slightly longer than half of central lobe's length; basal inner duct looped, ending in weakly sclerotised forceps; apical inner duct filamentous; forming one long coil; paramere slender; not exceeding central lobe; slender shaft widened shortly in front of apex to approximately circular expansion; at apex with four long setae; at outer side with four sensillae.

Etymology: The species name refers to he Brazilian state Amazonas, where it was collected.

\section{Diochus antennalis CAMERON, 1922 Figs $11 \mathrm{~A}-\mathrm{C}, 38 \mathrm{H}, 42 \mathrm{~A}$}

\section{Diochus antennalis CAMERON, 1922: 116}

Type material examined: Syntypes: Grenada: 2 males, 2 females, Balthazar (Windward side), leg. H.H. Smith, \#135, \#72, \#40, \#339; 1 female, Mount Gay East (Leeward side), W.I., leg. H.H. Smith, \#241; 1 female, Chantilly Est. (Windward side), W.I., leg. H.H. Smith, \#211. The male \#135 was selected as lectotype (BMNH).

Additional material examined: Grenada: 2 males, Chantilly Est. (Windward side), W.I., leg. H.H. Smith, \#10, 
\#339 (NMW); Costa Rica: Guanacaste Prov., Nicoya Peninsula, Rd. Playa Grande > Matapalo (10²0.30'$\left.21.14^{\prime} \mathrm{N}, \quad 85^{\circ} 48.46^{\prime}-50.43^{\prime} \mathrm{W}\right), \quad 10-80 \mathrm{~m}$ elev., forest remnants, meadows, fincas, collected by car net, male, 15.12.2013, leg. Schülke \& Grünberg (UIC); Heredia Prov., $3 \mathrm{~km}$ S Puerto Viejo, OTS La Selva, $100 \mathrm{~m}$ elev., male, Oct. 1992, leg. P. Hanson (KNHM); Columbia: Vichada, PNN El Tuparro Cerro Tomás $\left(5^{\circ} 21^{\prime} \mathrm{N}, 67^{\circ} 51^{\prime} \mathrm{W}\right), 140 \mathrm{~m}$ elev., malaise trap, 8.-18.8.2000, leg. W. Villalba \#M513 (KNHM); Guyana: Kurupukari $\left(4^{\circ} 40^{\prime} \mathrm{N}, 58^{\circ} 40^{\prime} \mathrm{W}\right)$, Malaise trap/flight intercept trap, male, Sept.-Nov. 1992 (BMNH); Bolivia: Santa Cruz Dept., Saavedra, Agr. Exp. Sta., blacklight trap, male, 28.12.1959, leg. R.B. Cumming (FMNH).

Diagnosis: The parameres of D. antennalis resemble those of the D. schaumii-group, because they are slightly widened at apex. However, the endophallus with the funnel-like widened basal inner duct and the presence of an apical inner duct show that it belongs to the $\mathrm{D}$. inornatus-group. It is one of the smallest species of the group known so far. Only $D$. tricolor is similarily small. It can be differentiated from that species by the unicoloured yellow colouration and the different shape of the paramere. In contrast to D. tricolor, D. antennalis has a weak microsculpture on the vertex.

Description: Length: $3.1 \mathrm{~mm}$. Colouration: light brown; head and abdominal segments III-VI slightly darker; legs and antennae yellow, except penultimate antennomeres indistinctly darker.

Head $0.44 \mathrm{~mm}$ long, $0.32 \mathrm{~mm}$ wide; eyes not prominent; small; EL : $\mathrm{HL}=0.22$; temples 2.5 times as long as eyes; temples divergent to posterior angles; PW : EW $=1.25$; posterior angles shortly rounded; posterior margin slightly concave; setiferous punctation moderately dense and deep; clypeus irregularly punctate; vertex with moderately wide impunctate midline; adjacent to midline with row of five punctures, divergent to anterior edge of eyes; between central row and eyes with irregular supraocular punctation; temples more densely punctate; transversely or diagonally striate microsculpture extremely weak; surface shiny.

Antennae slightly longer than head and half of pronotum combined; first antennomere thicker and longer than following antennomeres; second and third antennomere conical; approximately twice as long as at their apical width; length of following antennomeres decreasing; fourth slightly longer than wide; approximately 1.5 times as wide as long; all antennomeres pubescent and with apical setae.

Pronotum $0.51 \mathrm{~mm}$ long, $0.41 \mathrm{~mm}$ wide; widest near middle; sides approximately parallel; anterior margin convergent to small neck; slightly convergent to shortly rounded posterior margin; posterior margin slightly convex; lateral margin fine; in dorsal aspect, visible in posterior third; setiferous punctation sparse; transverse row of four punctures divergent posteriad; in poste- rior half two pairs of punctures; close to anterior angles another puncture and several setiferous punctures along lateral margin; without microsculpture, but with sparse irregular micro-punctures; surface polished.

Elytra $0.51 \mathrm{~mm}$ long, $0.53 \mathrm{~mm}$ wide; sides divergent to posterior angles; shoulders obtuse; posterior angles nearly rectangular; posterior margin slightly triangularly emarginate; setiferous punctation in irregular rows of five to six punctures; inner row adjacent to suture line; two additional lateral rows in equal distance; several punctures along lateral margin; irregular coriaceous ground sculpture weak; surface less shiny than head and pronotum.

Abdomen densely pubescent.

Aedeagus with thick seminal vesical, sligtly longer than half of central lobe, basal inner duct with funnel-like apical widened forceps; apical inner duct filamentous; with one coil; paramere slender; slightly widened at apex to triangular transparent plate; at apex with three long setae; base of shaft with four sensillae.

Spermatheca $0.30 \mathrm{~mm}$ long, $0.25 \mathrm{~mm}$ wide; bursa copulatrix in central position to coiled duct; coiled duct with numerous regular coils.

\section{Diochus hanagarthi spec. nov.

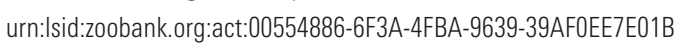 Figs $9 \mathrm{~A}-\mathrm{C}, 38 \mathrm{G}, 41 \mathrm{H}$}

Type material: male Holotype: Peru: Huanuco, Llullapichis, Panguana station $\left(74^{\circ} 56^{\prime} \mathrm{W}, 9^{\circ} 37^{\prime} \mathrm{S}\right)$, cut forest planted with Manihot, 6.10.1975, leg. W. Hanagarth (UIC).

Paratypes: Ecuador: Pastaza Prov., $1000 \mathrm{~m}$ elev., $25 \mathrm{~km}$ N Puyo, 1000 m elev., Berlese, cloud forest litter, female, 13.7.1976, leg. S. Peck (FMNH); Peru: same place as holotype, but Cocha, 4 females, 9.5.1976, leg. W. Hanagarth (UIC); same place as holotype, cut forest, 3 males, 2 females, 4.5.1976, leg. W. Hanagarth (UIC); same place as holotype, pitfall trap, river bank pasture, 10.-24.1.1984, leg. M. Verhaagh (UIC); Dept. Loreto, Campamento San Jacinto $\left(75^{\circ} 51.77^{\prime} \mathrm{W}, 2^{\circ} 18.75^{\prime} \mathrm{S}\right), 175-215 \mathrm{~m}$ elevation, collected by flight intercept trap, female, 3.7.1993, leg. R. Leschen, \#10 (KNHM); Loreto Dept. Iquitos, $90 \mathrm{~m}$ elevation, collected by light intercept trap, female, 5.5.1992, leaf litter in the forest, female, 8.5.1992, leg. J. Danoff-Berg (KNHM); Tambopata Prov., $15 \mathrm{~km} \mathrm{NE}$ Pto. Maldonado $\left(69^{\circ} 03^{\prime} \mathrm{W}, 12^{\circ} 33^{\prime} \mathrm{S}\right), 200 \mathrm{~m}$ elevation, under leaves by stream, 1 male, 4 females, 5.7.1989, 1 male, from liana fruit fall, 25.6 .1989 leg. J. Ashe, R. Leschen \#397 \#269 (KNHM); Junin Dept., La MercedVilla Rica Rd. (10 $\left.57.12^{\prime} \mathrm{S}, 75^{\circ} 17.30^{\prime} \mathrm{W}\right), 900 \mathrm{~m}$ elev., flight intercept trap, female, 15.-21.10.1999, leg. R. Brooks, \#PERU1B99090 (KNHM); Cuzco Dept., Consuelo, Manu rd. km 165, litter along stream, 1 male, 1 female, 4.10.1982, leg. L.E. Watrous \& G. Mazurek (FMNH); Madre do Dios Dept., Tambopata, litter at swamp edge, 2 females, 28.10.1982, leg. L.E. Watrous \& G. Mazurek 
(FMNH); Bolivia: Santa Cruz Dept., 3.7 km SSE Buena Vista, Hotel Flora y Fauna $\left(63^{\circ} 33.15^{\prime} \mathrm{W}, 1^{\circ} 29.95^{\prime} \mathrm{S}\right)$, 400-440 m elevation, primary forest, flight intercept trap, female, 3.-9.11.2002, leg. R. Leschen \#BOL1L02052 (KNHM); Cochabamba, 117 km E Yungas, Lagunitas $\left(17^{\circ} 06.2^{\prime} \mathrm{S}, 65^{\circ} 40.57^{\prime} \mathrm{W}\right), 1000 \mathrm{~m}$ elev., montane forest litter, female, 1.2.1999, leg. R. Anderson \#BOLA99014 (KNHM); Cochabamba, $67.5 \mathrm{~km}$ NE Est. Biol. Valle del Sajita, Univ. de San Simon $\left(1^{\circ} 06.33^{\prime} S, 64^{\circ} 47.52^{\prime} \mathrm{W}\right)$, rain forest litter, female, 7.2.1999, leg. R. Anderson, \#BOL1A99027 (KNHM); Vaca Diez Prov., Beni Dept., $2 \mathrm{~km} \mathrm{NW}$ Tumichucua, forest, leaf litter in sunken area, female, 12. 8.1990, leg. P. Parrillo (FMNH); Brazil: Amazonas, Manaus, Ilha de Marchanteria (59 $58^{\prime} \mathrm{W}$, $3^{\circ} 15^{\prime} \mathrm{S}$ ), floating meadow, 2 males, 29.4.1981, leg. J. Adis (UIC); Paraguay: without more data, coll Kraatz (SDEI); Paraguari, Sapucai $\left(25^{\circ} 40^{\prime} \mathrm{S}, 56^{\circ} 55^{\prime} \mathrm{W}\right), 190 \mathrm{~m}$ elev., light trap, 1 male, 3 females, 4.-8.2.1995, leg. U. Drechsel

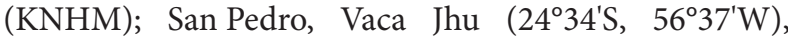
120 m elev., 1 male, 3 females, 5.-8.3.1993. leg. Drechsel (KNHM); Guairá, Calle Florida, at light, 2 females, 7.2.1994, leg. Drechsel (KNHM); same Prov., Melgarejo, Tacuara Creek, flood detritus, female, 20.10.1994, leg. Drechsel (KNHM); Alto Paraguay, Madrejon, at light, 2 males, 1 female, 15.5.1995, leg. Drechsel (2 KNHM, 1 UIC); Argentina: Catamarca, Cencepción, female, 5.12.1971, leg. L. Herman (AMNH); San Juan Prov., S. of Astica Chucuma $\left(31^{\circ} 04^{\prime} \mathrm{S}, 67^{\circ} 17^{\prime} \mathrm{W}\right)$, leaf litter nr. stream, female, 4.11.1995, leg. L. Herman (AMNH); San Juan Prov., NW of San Augustin de Valle Fertil, La Rinconada $\left(30^{\circ} 47^{\prime} \mathrm{S}, 67^{\circ} 28^{\prime} \mathrm{W}\right)$, leaf litter nr. stream, $1100 \mathrm{~m}$ elev., female, 5.11.1995, leg. L. Herman (AMNH); Tucuman, $15 \mathrm{~km} \mathrm{~N}$ Tucuman, Rio Sali, female, 30.12.1971, leg. L. Herman (AMNH); San Luis Prov., Aguas Buenas $\left(32^{\circ} 35.05^{\prime} \mathrm{S}, 64^{\circ} 57.01^{\prime} \mathrm{W}\right)$, litter nr. stream, female, 9.12.2000, leg. L. Herman (AMNH).

Diagnosis: $D$. hanagarthi closely resembles $D$. inornatus in size, colouration and by the thick and long seminal vesical of the endophallus. It can be separated from $D$. inornatus by the shorter head and temples. EL : HL in $D$. inornatus is 0.21 , whereas it is 0.29 in D. hanagarthi. The temples in D. inornatus are 1.8 times as long as eyes, whereas they are only 1.3 times as long as eyes in D. hanagarthi. The seminal vesical is shorter than in $D$. inornatus and the coiled apical duct slightly larger.

Description: Length: $3.8 \mathrm{~mm}$. Colouration: brown; pronotum yellow; elytra yellowish with indistinct brownish spot; antennae unicoloured dark yellow; legs yellow.

Head: $0.50 \mathrm{~mm}$ long, $0.43 \mathrm{~mm}$ wide; eyes slightly prominent; large; half as long as temples; $\mathrm{EL}: \mathrm{HL}=0.29$; temples slightly divergent to posterior angles; $\mathrm{PW}: \mathrm{EW}=1.18$; posterior angles widely rounded; not angulate; neck slightly shorter than half of head's width; setiferous punctation deep; along wide impunctate midline with ca. 6 punctures in longitudinal line; temples laterally with moderately dense punctation; interstices between punctures approximately twice as wide as diameter of punctures; without microsculpture; surface shiny.

Antennae as long as head and half of pronotum combined; first antennomere nearly twice as long as second and slightly thicker; second and third antennomere conical and equally long; twice as long as apical width; following antennomeres distinctly shorter; approximately quadrate; basal 6 antennomeres with long apical setae; all antennomeres pubescent.

Pronotum: $0.62 \mathrm{~mm}$ long, $0.50 \mathrm{~mm}$ wide; sides nearly parallel; anterior and posterior angles widely rounded, not angulate; in dorsal aspect, fine lateral margin only visible shortly in front of posterior angles; wide midline impunctate; impunctate area much wider than lateral punctate area; few setiferous punctures in lateral area; setae long and thick; on average, interstices between punctures three to four times as wide as diameter of punctures; without microsculpture; surface shiny.

Elytra: $0.66 \mathrm{~mm}$ long, $0.66 \mathrm{~mm}$ wide; widest close to posterior angles; sides convergent to shoulders; shoulders distinct, but obtusely rounded; posterior margin triangularly emarginate; setiferous punctures in longitudinal lines with five to six punctures; on average, interstices between punctures four times as wide as diameter of punctures; setae long and thick, in particular, laterally; without microsculpture; surface shiny.

Abdomen densely pubescent.

Aedeagus with seminal vesical of endophallus two third as long as total length of central lobe; basal inner duct looped, apical inner duct with one large coil ending at apex; paramere reaching apex of central lobe; slender; nearly parallel from base to apex; only very slightly widened in apical part; without any process.

Spermatheca $0.42 \mathrm{~mm}$ long, $0.22 \mathrm{~mm}$ wide; bursa copulatrix in central position of approximately oval coiled duct; coiled duct widest at middle; sides in posterior half smoothly narrowed; anterior half nearly parallel.

Etymology: The species name honours the collector Dr. Werner Hanagarth, who unfortunately passed to early.

\section{Diochus hermani spec. nov.

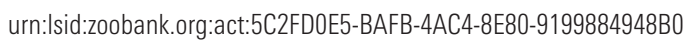 Figs $15 \mathrm{~A}-\mathrm{C}, 38 \mathrm{I}, 42 \mathrm{D}$}

Type material: male Holotype: Argentina, Cordoba Prov., W of Pampa de Achala ( $\left.31^{\circ} 46^{\prime} \mathrm{S}, 64^{\circ} 55.14^{\prime} \mathrm{W}\right), 1320 \mathrm{~m}$ elev., 10.12.2000, leg. L. Herman, \#3078 (AMNH).

Paratypes: Argentina, Tigre, female, leg. Breyer (FMNH); Brazil: Estado Santa Catarina, Nova Teutona $\left(52^{\circ} 23^{\prime} \mathrm{W}\right.$, $\left.27^{\circ} 11^{\prime} \mathrm{S}\right), 300-500 \mathrm{~m}$ elev., 2 males, 11 females, 3.1954, leg. F. Plaumann (FMNH, UIC).

Diagnosis: Among the species of the group, D. hermani closely resembles $D$. vicinus and $D$. plaumanni in size. $D$. hermani is darker than D. vicinus; in particular, 
the pronotum is not lighter than the head. Moreover, the head is more slender. The head is 1.35 times as long as wide, whereas it is only 1.15 times as long as wide in D. vicinus and 1.27 times as long as wide in D. plaumanni. The species can be easily identified by the specific shape of the paramere. Besides a short triangular process at base of the shaft another transparent process is developed near the apex. The apex has a asymmetric narrow trinagular process. In D. hermani the parameres are longer than the central lobe, whereas they are slightly shorter in D. vicinus. More differences to D. plaumanni are listed there.

Description: Length: $4.3 \mathrm{~mm}$. Colouration: dark brown, posterior half of elytra and legs yellow; antennomeres dark brown except antennomeres one to three yellow. Head $0.65 \mathrm{~mm}$ long, $0.48 \mathrm{~mm}$ wide; eyes slightly prominent; temples twice as long as eyes; $\mathrm{EL}: \mathrm{HL}=0.22$; slightly divergent posteriad; $\mathrm{PW}: \mathrm{EW}=1.16$, posterior margin slightly convex; setiferous punctation moderately deep and dense; wide midline from clypeus to posterior vertex impunctate; adjacent to impunctate midline with row of six punctures; on supraocular and on postoculare area irregularly punctate; on posterior vertex transverse rows of setiferous punctures; without microsculpture; surface polished.

Antenna as long as head and half of pronotum combined; first antennomere thicker than following ones; second and third antennomeres conical; second antennomere shorter than first and third; nearly twice as long as apical width; third antennomere slender; nearly three times as long as apical width; following antennomeres distinctly shorter and decreasing in length; fourth antennomere slightly longer than wide; tenth antennomere slightly wider than long; all antennomeres pubescent and with few long apical setae.

Pronotum $0.76 \mathrm{~mm}$ long, $0.56 \mathrm{~mm}$ wide; sides parallel; anterior third widely rounded; posterior margin shortly convex; lateral margin fine; in dorsal aspect, only visible in posterior half; setiferous punctation moderately deep and sparse; midline impunctate; adjacent to midline three pairs of punctures; interstice between anterior pair of punctures twice as wide as between posterior pairs of punctures; laterad, transverse row of three punctures; along lateral margin several setiferous punctures; without microsculpture, but with sparse micro-punctation; surface polished.

Elytra $0.76 \mathrm{~mm}$ long, $0.74 \mathrm{~mm}$ wide; shoulders obtuse; slightly widened posteriad; at posterior angles 1.2 times as wide as at shoulders; posterior angles nearly rectangular; posterior margin triangularly emarginate; setiferous punctation in irregular rows; inner row directly adjacent to suture line; laterad two rows on disc with four to five setiferous punctures; along lateral margin several setiferous punctures; surface with weak coriaceous ground sculpture, less shiny than head and pronotum

Abdomen densely pubescent.
Aedeagus moderately broad; seminalvesical of endophallus thick; 0.6 times as long as total length of central lobe; basal inner duct looped; ending in thick widened funnel; apex of funnel with forceps; apical filamentous duct forming one large coil; paramere projecting central lobe; near base with triangular prominence; in anterior part slightly curved; in anterior third with obtuse short lobe; apex angled ending in transverse elongate process; at apical edge with four long setae; between triangular and obtuse process several sensillae.

Etymology: The species name honours the collector of the species, Dr. Lee Herman, who collected intensively in the Neotropics.

\section{Diochus hibbsi spec. nov.

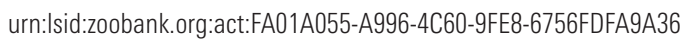 Figs 17A-C, 38J, 42F}

Type material: male Holotype: Ecuador: Sucumbios, Sacha Lodge $\left(0^{\circ} 5^{\prime} \mathrm{S}, 76^{\circ} 5^{\prime} \mathrm{W}\right), 270 \mathrm{~m}$ elevation, collected by malaise trap, 4.-14.3.1994, leg. Hibbs (KNHM).

Paratypes: female, with same data as holotype (UIC); female, same location and same collector, but 14.-24.5.1994 (KNHM); Peru: Tambopata Prov. 15 km NE Pto. Maldonado, $200 \mathrm{~m}$ elevation, liana fruit fall, female, 7.7.1989, leg. J. Ashe, R. Leschen (KNHM); Madre de Dios, Tambopata, rotten figs, bamboo litter, 1 male, 2 females, 28.10.1983, leg. L.E. Watrous \& G. Mazurek (FMNH); Manu Prov., Parque Nat. Manu, Zona Res., Rio Manu, Cocha Juarez, trail nr. Manu Lodge, flight intercept trap, male, 18.-24.9.1991, leg. A. Hartman (FMNH).

Diagnosis: Among the species of this group, D. hibbsi is characterised by the bicoloured pronotum with black anterior half and lighter brown posterior half. Moreover, the long antennae differentiate it from the similarly large $D$. vicinus. The antennae of $D$. hibbsi are similarly long as in D. longicornis and are as long as head and of pronotum combined, whereas in D. vicinus antennae are only as long as head and half of pronotum combined. The thick globular seminal vesical of the endophallus is also characteristic within the group and the paramere has a specific shape.

Description: Length: $4.5 \mathrm{~mm}$. Colouration: brown; pronotum light brown with anterior half darkened; head and elytra blackish; posterior margin of elytra lighter brown; legs and antennae yellowish.

Head: $0.71 \mathrm{~mm}$ long, $0.52 \mathrm{~mm}$ wide; eyes slightly prominent; large; temples 1.5 times as long as eyes; $\mathrm{EL}: \mathrm{HL}=0.29$; temples slightly divergent; $\mathrm{PW}: \mathrm{EW}=1.14$; posterior angles widely rounded; posterior margin nearly semi-circular; impunctate midline convergent from clypeus to posterior vertex; adjacent to midline with row of seven setiferous punctures; additional irreg- 
ular lines of setiferous punctures on supraocular area; punctures differing in size; postocular area more densely punctate; without microsculpture; surface polished.

Antennae nearly as long as head and pronotum combined; first antennomere thicker than following antennomeres; second antennomere twice as long as apical width; third antennomere three times as long as apical width; following antennomeres longer than wide, but with decreasing length; fourth antennomere 1.4 times as long as wide; tenth antennomere only 1.1 times as long as wide; all antennomeres densely pubescent and with few apical setae.

Pronotum: $0.77 \mathrm{~mm}$ long, $0.66 \mathrm{~mm}$ wide; slightly divergent to posterior angles; anterior angles widely and evenly rounded; posterior angles obtusely rounded; lateral margin weak; in dorsal aspect visible in posterior half; setiferous punctation sparse and moderately deep; along impunctate midline three pairs of punctures; interstice between anterior pair of punctures more than twice as wide as interstices between posterior two pairs; on lateral disc and along lateral margin few more setiferous punctures; very sparse micro-punctation between larger setiferous punctures; without microsculpture; surface polished.

Elytra $0.81 \mathrm{~mm}$ long, $0.92 \mathrm{~mm}$ wide; sides divergent from shoulders to posterior angles; width at posterior angles 1.3 times as wide as at shoulders; shoulders forming obtuse angles; posterior margin with triangular emargination; setiferous punctation in irregular rows of six to eight punctures; inner row adjacent to suture and three additional rows on disc; with moderately deep coriaceous ground sculpture; surface less shiny than pronotum and head.

Abdomen densely pubescent.

Aedeagus thick; seminal vesical of endophallus slightly oval, but nearly globular; basal inner duct looped; ending in sclerotised funnel; apical inner duct with one coil; paramere not projecting central lobe; in basal shaft folded; apex rounded with two long setae and with asymmetic triangular process and another shorter triangular process in front of apex; with subapical transparent sensory area; several sensillae in medial shaft.

Spermatheca $0.33 \mathrm{~mm}$ long, $0.27 \mathrm{~mm}$ wide; bursa copulatrix in central position to coiled duct; coiled duct oval, but nearly globular.

Etymology: The species name honours the collector P. Hibbs, who extensively collected rove beetles in the Ecuadorian sub-montane rainforest at Sacha Lodge.

\section{Diochus inornatus SHARP, 1885}

Figs $8 \mathrm{~A}-\mathrm{C}, 38 \mathrm{~F}, 41 \mathrm{G}$

Diochus inornatus SHARP, 1885: 466

Type material examined: 2 syntypes: Panama, male, Bugaba 800-1000 feet elevation, leg. Champion (BMNH); female, Pena Blanca, 3000-4000 feet, leg. Champion $(\mathrm{BMNH})$.
Further material examined: Mexico: Veracruz, $10 \mathrm{mi}$. W Coatzacoalcos, male, 15.8.1966, leg. J.\&W. Ivie (AMNH); Oaxaca, 10.8 mi S Valle Nacional, Hwy 175, under bark, montane tropical forest, $1000 \mathrm{~m}$ elev., male, 26.4.1977, leg. J. Ashe (FMNH); Jalisco, Puerto Mazos, $100 \mathrm{mi}$ SW Autlán, $4400 \mathrm{ft}$. elev., Berlese, litter oak tropical decid. forest, 2 females, 25.9.1973, leg. A. Newton (FMNH); Nicaragua: Rio San Juan Dept., $60 \mathrm{~km} \mathrm{SE}$ San Carlos, Refugio Bartola $\left(84^{\circ} 20.30^{\prime} \mathrm{W}\right.$, $\left.10^{\circ} 58.40^{\prime} \mathrm{N}\right), 100 \mathrm{~m}$ elevation, collected by mercury vapor/UV light, male, 30.5.2002, leg. R. Brooks, Z. Falin \#NIC1BFC02 129 (KNHM); Costa Rica: Limon Prov., Rd. Bribri > Bratsi $\left(9^{\circ} 33.45^{\prime}-35.45^{\prime} \mathrm{N}\right.$, $\left.83^{\circ} 52.30^{\prime}-53.17^{\prime} \mathrm{W}\right), \quad 30-50 \mathrm{~m}$ elevation, along river bank, secondary forest, Fincas, car net, male, 2.12.2013, leg. M. Schülke \& B. Grünberg (MSC); Rd. Barrigones (Osa) > Chacarita $\left(8^{\circ} 35^{\prime}-48^{\prime} \mathrm{N}, 83^{\circ} 15^{\prime}-26^{\prime} \mathrm{W}\right)$, 0-250 $\mathrm{m}$ elevation, pastures, plantages, devasted forest, car net, male, 11.12.2012, leg. Schülke \& Grünberg (MSC); Osa peninsula, Rd. Drake > Rincon de Osa $\left(8^{\circ} 41^{\prime}-42^{\prime} \mathrm{N}, 83^{\circ} 29^{\prime}-40^{\prime} \mathrm{W}\right), 0-400 \mathrm{~m}$ elevation, car net, male, 9.12.2012, leg. Schülke \& Grünberg (UIC); Vulcan Rincon e la Vieja, Rd. Hacienda Guachipelin $>$ Santa Maria $\left(10^{\circ} 42.43^{\prime}-45.11^{\prime} \mathrm{N}, 8^{\circ} 20.15^{\prime}-22.45^{\prime} \mathrm{W}\right)$, $500-700 \mathrm{~m}$ elevation, dry forest \& pasture, car net, female, 4.12.2012, leg. Schülke \& Grünberg (UIC); Alajuela, San Ramon, $5 \mathrm{~km} \mathrm{W,} 1200 \mathrm{~m}$ elevation, 1 male, 1.-31.7.1997, leg. P. Hanson \#CR1HAN92-97 (KNHM); Puntarenas, R.F. Golfo Dulce, $24 \mathrm{~km} \mathrm{~W}$ Piedras Blancas, $200 \mathrm{~m}$ elevation, 1 male, Jan.-Feb. 1992, leg. P. Hanson (KNHM); S.M. Barranca, male, 12.-16.2.1940, leg. A. Bierig (FMNH); San Mateo, Jesus Maria, male, 27.10.1939, leg. A. Bierig (FMNH); Desmonte, $500 \mathrm{~m}$ elev., male, 28.2.-2.3.1939, leg. A. Bierig (FMNH); Panama: Chiriqui Prov., $2 \mathrm{~km} \mathrm{~S}$ Cuernavaca Camp, Rincon Vly., litter on semi-cleared hillside between rock \& log, 1 male, 1 female, 16.1.1981, leg. W. Suter (FMNH); Panama Prov., SW of Campana, Cerro Campana $\left(8^{\circ} 40.54^{\prime} \mathrm{N}, 79^{\circ} 55.28^{\prime} \mathrm{W}\right)$, litter near stream, $750 \mathrm{~m}$ elev., female, 24.5.2001, leg. L. Herman \& W. Opitz (AMNH); Chiriqui Prov., Qda., Laguna nr. Rio San Felix, $725 \mathrm{~m}$ elev., litter on sand pocket S. bank, 4 males, 4 females, 19.1.1981, leg. W. Suter (FMNH); Bocas del Toro Prov., Almirante, forest floor litter, female, 1.4.1959, leg. H.S. Dybas (FMNH); Bugaba, 800-1500 ft. elev., leg. Champion (FMNH, exchange with BMNH); Colombia: Meta, PNN Tinigua, Caño Nevera $\left(73^{\circ} 48^{\prime} \mathrm{W}, 2^{\circ} 11^{\prime} \mathrm{N}\right), 390 \mathrm{~m}$ elevation; malaise trap, 1 female, 23.1.-7.2.2002, leg. C. Sánchez \#M2330 (KNHM); Vichada, PNN El Tuparro, Cerro Tomás $\left(67^{\circ} 51^{\prime} \mathrm{W}, 5^{\circ} 21^{\prime} \mathrm{N}\right), 140 \mathrm{~m}$ elevation, malaise trap, 1 female, 22.5.-3.6.2001, leg. I. Gill \#M1789 (KNHM); French Guiana: Caussade $\left(52^{\circ} 57^{\prime} \mathrm{W}, 5^{\circ} 10^{\prime} \mathrm{N}\right)$, car net, 5 males, 18 females, 6.11.20122, 7.11.2011, leg. T. Struyve (10 TSC, 13 UIC); Coralie $\left(52^{\circ} 21^{\prime} \mathrm{W}, 4^{\circ} 30^{\prime} \mathrm{N}\right)$, car net, 2 females, 15.11.2011, leg. T. Struyve (1 TSC, 1 UIC); Barrage de Petit Saude $\left(53^{\circ} 02^{\prime} \mathrm{W}, 5^{\circ} 03^{\prime} \mathrm{N}\right)$, car net, female, 15.11.2011, leg. T. Struyve (TSC); Ecua- 
dor: Sucumbios, Sacha Lodge $\left(0^{\circ} 5^{\prime} \mathrm{S}, 76^{\circ} 5^{\prime} \mathrm{W}\right), 270 \mathrm{~m}$ elev., malaise trap, female, 14.-24.3.1994, leg. Hibbs (KNHM); Brazil: Pará, 5 km E Belém, soil-litter layer in primary "terra firme" forest, male, 30.5.1973, leg. R.T. Schuh (AMNH); $8 \mathrm{~km} \mathrm{E} \mathrm{Belém,} \mathrm{Ananindéua,}$ secondary growth forest, Plot \#2, 3 females, 30.6.1973, leg. R.T. Schuh (AMNH); Minas Gerais, Pampulha, UFMG campus, $\mathrm{BH}\left(19^{\circ} 52^{\prime} \mathrm{S}, 43^{\circ} 58^{\prime} \mathrm{W}\right), 830 \mathrm{~m}$ elev., malaise trap, female, 27.11.1996, leg. J.C.R. Fontenelle \#BRA1F96097 (KNHM).

Diagnosis: The species is characterised by the thick and long seminal vesical of the endophallus and the apical coiled duct similar as in D. hanagarthi. But the seminal vesical is still thicker and longer than in D. hanagarthi. The coiled apical duct is nearly on the same level as the upper edge of the seminal vesical. The head is smaller and more elongate than in D. hanagarthi and the temples are longer, approximately 2.5 times as long as eyes. EL : HL is only 0.21 in D. inornatus, but 0.29 in D. hanagarthi.

Description: Length: $3.8-4.1 \mathrm{~mm}$. Colouration: dark to light brown; pronotum lighter brown to dark orange; posterior margin of elytra slightly lighter brown; legs and base of antennae light brown to yellowish; apical antennomeres slightly darker.

Head: $0.56 \mathrm{~mm}$ long, $0.44 \mathrm{~mm}$ wide; eyes not prominent; small; temples twice as long as eyes; $\mathrm{EL}: \mathrm{HL}=0.21$; temples approximately parallel; $\mathrm{PW}: \mathrm{EW}=1.10$; posterior angles widely rounded; neck one third as wide as head; clypeus impunctate; anterior vertex with two irregular rows of deep setiferous punctures from anterior edge of eyes to half distance between eyes and neck; three to four punctures in each row; postocular area with more setiferous punctures; posterior vertex with few weaker and sparser setiferous punctures; without microsculpture; surface shiny.

Antennae as long as head and half of pronotum combined; first antennomere slight thicker than antennomeres two and three; basal three antennomeres more or less conical; one third longer than at their apical width; following antennomeres approximately quadrate; apical antennomeres slightly wider than long; all antennomeres pubescent and with few longer apical setae.

Pronotum: $0.68 \mathrm{~mm}$ long, $0.50 \mathrm{~mm}$ wide; sides parallel; lateral margin extremely fine; nearly invisible in dorsal aspect; anterior and posterior angles widely rounded; with very sparse setiferous punctation; narrow midline impunctate; two rows of three to four setiferous punctures adjacent to midline; in anterior half distance between punctures wider than in posterior half; another row of punctures laterad and between both rows few single punctures; without microsculpture; surface shiny.

Elytra: $0.66 \mathrm{~mm}$ long, $0.68 \mathrm{~mm}$ wide; widest close to posterior margin; shoulders obtuse; setiferous punctation partly in longitudinal rows; first row of punctures adjacent to suture; lateral rows irregular; surface weakly coriaceous; less shiny than head and pronotum.

Abdomen with dense pubescence; among pubescent punctation with few longer setae.

Aedeagus thick; seminal vesical long and thick; at least three fourth as long as total length of central lobe; basal inner duct looped; apical inner filamentous duct shortly coiled; paramere short and narrow; elongate and without prominences; three long setae at apex close together.

Spermatheca: $0.41 \mathrm{~mm}$ long, $0.22 \mathrm{~mm}$ wide; bursa copulatrix in asymmetric position of coiled oval duct; sides of coiled duct parallel at middle.

\section{Diochus newtoni spec. nov.

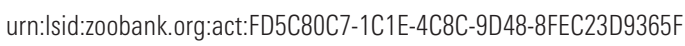 Figs 19A-C, 38K, 42G}

Type material: male, Holotype: Panama: Panama Prov., Cerro Campano, $3200 \mathrm{ft}$. elev., Berlese, cloud forest leaf litter, 14., 23.2.1976, leg. A. Newton (FMNH).

Paratypes: 3 males, 4 females with same data as holotype (FMNH, UIC).

Diagnosis: Regarding the overall shape of the aedeagus, $D$. newtoni is closely related to D. schuelkei. The paramere is nearly identical to that of D. schuelkei, except the structure of the lateral triangular process, which is straightly upright in D. schuelkei, but curved and spoon-like in D. newtoni. Furthermore, colouration of D. newtoni is brown, whereas it is nearly black in D. schuelkei. It can be easily identified by the extremely small eyes from all other species of the group. The eyes are still smaller than those of D. inornatus.

Description: Length: $4.7 \mathrm{~mm}$. Colouration: dark brown, legs and antennae light brown.

Head: $0.60 \mathrm{~mm}$ long, $0.50 \mathrm{~mm}$ wide; eyes small; not prominent; EL : HL 0.15; temples five times as long as eyes; distinctly divergent to posterior angles; $\mathrm{PW}: \mathrm{EW}=1.30$, posterior margin curved; posterior angles obtuse; setiferous punctures deep, wide midline impunctate; along midline with line of five to six setiferous punctures; laterad with dense punctation; without microsculpture; surface shiny.

Antennae as long as head and half of pronotum combined; first antennomere elongate; nearly as long as second and third antennomere combined; second and thrid antennomere conical; nearly twice as long as apical width; antennomeres four and five quadrate; following antennomere wider than long; eighth antennomere 1.5 times as wide as long; all antennomeres with moderately long stetae at apex; all antennomeres exept first antennomere pubscent.

Pronotum: $0.74 \mathrm{~mm}$ long, $0.58 \mathrm{~mm}$ wide; sides aproximately parallel; anterior margin widely rounded; without distinct anterior angles; posterior margin shortly rounded 
with weak obtuse angles; lateral margin extremely fine; in dorsal aspect nearly invisible; setiferous punctures deep; along wide impunctate midline with three pairs of punctures in anterior half; interstice between anterior pair nearly twice as wide as between posterior pairs; few more punctures laterad; along lateral margin several punctures; wihtout microsculpture; surface polished.

Elytra: $0.65 \mathrm{~mm}$ long, $0.71 \mathrm{~mm}$ wide; sides posteriorly divergent; widest at posterior margin; shoulders obtusely rounded; deep setiferous punctation in four irregular lines; four lines on disc; first line at suture with 7 to 8 punctures; along lateral margin with several long setae; with moderately deep coriaceous ground sculpture; surface less shiny than head and pronotum.

Abdomen with dense pubescence.

Aedeagus with thick seminal vesical; 0.6 times as long as total length of central lobe; basal inner duct looped; ending in wide funnel-like structure with apical forceps; filamentous apical duct forming one coil; parameres projecting central lobe; with two long setae at apex; laterad with trinagular process; process apically widened to irregular spoon-like structure; shaft with few sensillae at base. Spermatheca $0.26 \mathrm{~mm}$ long; $0.11 \mathrm{~mm}$ wide; bursa copulatrix in asymmetric position to coild duct; coiled duct oval; shoe-like.

Etymology: The species is named to honour the tremendous work of Alfred Newton, Chicago, USA, for the knowledge of the Neotropical Staphylinidae.

Diochus novus spec. nov.

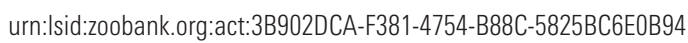
Figs $12 \mathrm{~A}-\mathrm{C}, 38 \mathrm{~L}, 42 \mathrm{H}$

Type material: male, Holotype: Brazil: Pará, Jacareacanga, 10.1959, leg. M. Alvarenga (INPA).

Paratypes: Brazil: Santa Catarina, without more details, 1 male, leg. P.E. Klimsch (NMW); Mato Grosso, Primavera do Leste, Ilha Grande farm $\left(54^{\circ} 14.6^{\prime} \mathrm{W}, 15^{\circ} 26.6^{\prime} \mathrm{S}\right)$, Cerrado forest, litter, male, 8.4.2014, leg. K. Peña Peña (UIC); Campo Verde, Rio Engano farm (54 $50.7^{\prime} \mathrm{W}$, $\left.15^{\circ} 23^{\prime} \mathrm{S}\right)$, Cerrado forest, litter, female, 14.3.2014, leg. K. Peña Peña (UIC); Pará, Ipean, litter in "Mocambo", 1 male, 1 female, 2.7.1973, leg. R.T. Schuh (AMNH); Belém, Ipean, primary terra firme forest, plot \#4, female, 6.6.1973, leg. R.T. Schuh (AMNH); Rio de Janeiro, female, leg. Squires, Sharp coll. \#1905-313 (BMNH); Bolivia: Dept. Beni, Prov. Vaca Diez, 2 km NW Tumichucua, forest, leaf litter in sunken area, 1 male, 3 females, 12.8.1990, leg. P. Parillo (FMNH).

Diagnosis: Among the species of the group, D. novus resembles $D$. hanagarthi and $D$. inornatus in size and colouration. It is slightly shorter than the two species. The eye length is similar to that of D. inornatus and, thus, shorter than in D. hanagarthi. In contrast, the slightly posteriorly divergent head is similar to $D$. hanagarthi and different from the parallel head of $D$. inornatus. However, it is mainly differentiated by the characteristic aedeagus with the paramere longer than the central lobe and the long hook-like apex.

Description: Length $3.6 \mathrm{~mm}$. Colouration: dark brown; pronotum slightly lighter, but still dark; legs and antennae yellow with antennomeres four to eleven dark yellow to light brown.

Head: $0.51 \mathrm{~mm}$ long, $0.42 \mathrm{~mm}$ wide; eyes small, not prominent; temples three times as long as eyes; $\mathrm{EL}: \mathrm{HL}=0.21$; temples moderately divergent posteriad; $\mathrm{PW}: \mathrm{EW}=1.19$; posterior angles widely rounded; wide midline impunctate; adjacent to midline in anterior two third with row of four setiferous punctures; laterad to medial row of punctures irregular setiferous punctation; postocular area and along posterior margin more setiferous punctures; on small parts with extremely weak microsculpture; remaining parts polished; surface shiny.

Antennae as long as head and half of pronotum combined; first antennomere slightly thicker than following antennomeres; following antennomeres decreasing in length; conical second and third antennomeres one third shorter than first antennomere; fourth antennomere still longer than wide; fifth quadrate; following antennomeres slightly wider than long; all antennomeres pubescent; basal antennomeres with few apical long setae.

Pronotum: $0.60 \mathrm{~mm}$ long, $0.52 \mathrm{~mm}$ wide; slightly divergent from anterior to posterior angles; anterior angles widely rounded; posterior angles indistinct; obtuse; lateral margin fine; in dorsal aspect, visible only in posterior third; setiferous punctation moderately deep; sparse; along impunctate midline with row of three pairs of punctures; interstice between anterior pair of punctures more than twice as wide than interstices between posterior pairs; laterad, few irregularly placed setiferous punctures; along lateral margin several punctures with long setae; without microsculpture; surface polished.

Elytra: $0.63 \mathrm{~mm}$ long, $0.65 \mathrm{~mm}$ wide; sides slightly divergent to posterior margin; shoulders shortly rounded; posterior margin triangularly emarginate; setiferous punctation in irregular longitudinal lines; first line adjacent to suture with seven to eight punctures; with weak coriaceous ground sculpture; surface shiny.

Abdomen densely pubescent.

Aedeagus with seminal vesical of endophallus slightly longer than half of length of central lobe; basal inner duct looped; ending in broad dark sclerotised apex; continued in widely coiled apical duct; paramere projecting central lobe; narrow shaft suddenly widened near apex to hooklike expansion; apex with four long setae at outer side; few sensillae on basal part of shaft.

Spermatheca $0.39 \mathrm{~mm}$ long, $0.18 \mathrm{~mm}$ wide; bursa copulatrix in asymmetric position to coiled duct; coiled duct oval; slightly narrower at middle than at both ends.

Etymology: The Latin word novus means new and refers to the fact that the species is new to science. 
Diochus plaumanni spec. nov.

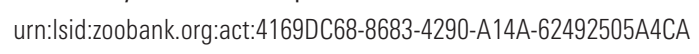

Figs $18 \mathrm{~A}-\mathrm{C}, 39 \mathrm{~B}, 42 \mathrm{E}$

Type material: male, Holotype: Argentina: Prov., P.N. Chaco, $100 \mathrm{~km}$ NW Restistencia, subtropical thorn forest, rotten logs \& sticks with fungus, sifted, 15.12.1990, leg. S. \& J. Peck (FMNH).

Paratypes: Argentina: Misiones Prov., P.N. Iguazu, TV tower road, $\log \&$ bark litter, female, 2.1.1991, leg. S. \& J. Peck (FMNH); same location, subtropical forest, treebase litter, $200 \mathrm{~m}$ elev. 2 females, 24.12.1990, leg. S. \& J. Peck (FMNH); 20 km SE P. Iguazu, Araucaria plantation treebase litter, female, 24.12.1990, leg. S. \& J. Peck (FMNH); same location, Salto Macuco, moss \& log bark, female, 26.12.1990, leg. S. \& J. Peck (FMNH); 20 km SE Puerto Iguazu, forest, treebase litter, male, 31.12.1990, leg. S. \& J. Peck (FMNH); Chaco Prov., P.N. Chaco, $100 \mathrm{~km}$ NW Restistencia, rotten logs \& sticks with fungus, 1 male, 1 female, 14.12.1990, leg. S. \& J. Peck (FMNH); same location, seasonal subtropical thorn forest, sifted rotted logs, leaf litter, treebase litter, 2 males, 3 females, 14.12.1990, leg. S. \& J. Peck (4 FMNH, 1 UIC); same location and habitat, 1 male, 1 female, 13.12.1990, leg. S. \& J. Peck (FMNH); Paraguay: Villa Rica, sifted, Auraucaria forest, 1 male, 1 female, 10.2.1924, leg. F. Schade (NMW); Brazil: Est. Santa Catarina, Nova Teutonia $\left(52^{\circ} 23^{\prime} \mathrm{W}, 27^{\circ} 11^{\prime} \mathrm{S}\right), 7$ females, 3.1954, leg. F. Plaumann (6 FMNH, 1 UIC); same location, 2 males, 7 females, 8.1953, leg. F. Plaumann (FMNH); Minas Gerais, Paso Quatro, 1 male, leg. Reichensperger (NMW).

Diagnosis: Regarding the structure of the paramere, D. plaumanni is closely related to D. hermani. In both species a short apical apendix is found at the paramere. In D. plaumanni, the apendix is slightly more curved than in D. hermani and the subapical prominence is absent. Moreover, $D$. hermani has four equally long apical setae, whereas $D$. plaumanni has only three uneqally long setae. $D$. hermani is significantly larger, the antennae are more elongate and the head is more parallel than in D. plaumanni (D. hermani: PW : EW = 1.21, D. plaumanni: PW : EW = 1.17).

Description: Length: $3.8 \mathrm{~mm}$. Colouration: light brown; head and anterior segments of abdomen slightly darker; antennomeres four to eleven darker than basal three antennomeres.

Head: $0.57 \mathrm{~mm}$ long, $0.45 \mathrm{~mm}$ wide; eyes small; EL : $\mathrm{HL}=0.20$, temples slightly divergent posteriad; PW : $\mathrm{EW}=1.17$; posterior angles widely rounded; posterior margin nearly semi-circular; setiferous punctation deep and dense; with wide impunctate midline; on supraocular and postocular area, interstices between punctures approximately as wide as diameter of punctures; microsculpture nearly absent, but on restricted areas with remains of extremely weak microsculpture.
Antennae as long as head and half of pronotum combined; first antennomere thicker and one third longer than second antennomere; second and third antennomere conical; twice as long as apical width; antennomeres four and five approximately quadrate; following antennomeres wider than long; eighth antennomere approximately 1.5 times as wide as long; all antennomeres with short apical setae and pubescent.

Pronotum: $0.68 \mathrm{~mm}$ long, $0.51 \mathrm{~mm}$ wide; sides parallel; in anterior third widely rounded to neck; posterior angles shortly rounded; obtuse; lateral margin fine; in dorsal aspect, visible in posterior half; setiferous punctation sparse; with wide impunctate midline; along midline four pairs of punctures in irregular position; laterad with few additional punctures; along lateral margin few setiferous punctures; between setiferous punctation with sparse micro-punctures; without microsculpture; surface polished.

Elytra: $0.57 \mathrm{~mm}$ long, $0.67 \mathrm{~mm}$ wide; sides slightly divergent from shoulders to posterior angles; shoulders shortly rounded; posterior angles nearly rectangular; posterior margin slightly emarginate; setiferous punctation in irregular rows of five to six punctures; with weak ground sculpture; surface less shiny than pronotum.

Abdomen with dense pubescence.

Aedeagus moderately slender; seminal vesical of endophallus thick; 0.7 times as long as total length of central lobe; basal inner duct looped; ending in wide funnel with apical forceps; continued to shortly coiled apically duct; at apex with hook-like sclerotised structures; parameres as long as central lobe; slender; at apex with recurved hook-like process; at apex of process two long setae and in short distance another shorter seta; at middle of shaft with two sensillae.

Spermatheca $0.47 \mathrm{~mm}$ long, $0.24 \mathrm{~mm}$ wide; bursa copulatrix placed inside coiled duct in symmetrical position.

Etymology: The species name honours Fritz Plaumann, who intensively collected Staphylinidae in southern Brazil during the mid of the $20^{\text {th }}$ century.

\section{Diochus schuelkei spec. nov.

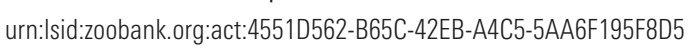 Figs $14 \mathrm{~A}-\mathrm{C}, 39 \mathrm{~A}, 43 \mathrm{~A}$}

Type material: male, Holotype: Costa Rica: $4 \mathrm{~km} \mathrm{~S} \mathrm{San}$ Vito, Jardin Botanico Wilson $\left(82^{\circ} 57.33^{\prime} \mathrm{W}, 8^{\circ} 47.05^{\prime} \mathrm{N}\right)$, compost heap, sifted, 8.12.2012, leg. M. Schülke (MSC). Paratypes: Guatemala: Zacapa, $3.5 \mathrm{~km}$ SE La Union $\left(89^{\circ} 16.5^{\prime} \mathrm{W}, 14^{\circ} 57.3^{\prime} \mathrm{N}\right), 1600 \mathrm{~m}$ elevation, berlesate forest litter, female, 25.6.1993, leg. Anderson \& Ashe \#93-15E (KNHM); Nicaragua: Jinotega, RN Cerro Kilambé (-85.69664, 13.56675), $1400 \mathrm{~m}$ elevation, cloud forest, Malaise trap, female, 23.-26.5.2011, LLAMA11 Ma-D-05-2-02 (KNHM); Costa Rica: Alajuela Prov., Rd. Rio Cuarto > Sarchi, N-side $\left(84^{\circ} 18.31^{\prime} \mathrm{W}, 10^{\circ} 12.31^{\prime} \mathrm{N}\right)$, dead wood and litter, sifted, female, 27.11.2013, leg. 
M. Schülke (UIC); San José, Zuruqui de Moravia $\left(84^{\circ} 1.0^{\prime} \mathrm{W}, 10^{\circ} 3.0^{\prime} \mathrm{N}\right), 1600 \mathrm{~m}$ elevation, flight intercept trap, 1 male, 1 female, 1.-30.3.1996, leg. P. Hanson, \#CR1H95-96 04 (1 KNHM, 1 UIC); Guanacaste, Guanacaste Conservation area, Patilla Field Station $\left(85^{\circ} 25.33^{\prime} \mathrm{W}, 10^{\circ} 59.22^{\prime} \mathrm{N}\right), 1000 \mathrm{~m}$ elevation, cloud-wet montane forest transit., litter, female, 14.2.1996, leg. R. Anderson, \#CR1A96 011D (KNHM); same location, but $610 \mathrm{~m}$ elevation, collected by flight intercept trap, male, 13.-15.7.2000, leg. R. Anderson, \#CR1ABF00 135 (KNHM); Heredia, Finca Murillo, 9 km NE Vara Blanca $\left(84^{\circ} 06.06^{\prime} \mathrm{W}, 10^{\circ} 14.17^{\prime} \mathrm{N}\right), 1450-1550$ m elevation, INBioOET-Atlas transect, female, 14.-20.2.2005, leg. R. Anderson \#CRA105 007 (KNHM); Vara Blanca, 1800$2000 \mathrm{~m}$ elev, 1 male, 1 female, 1936, leg. A. Bierig (FMNH); Cartago, P.N. Tapanti $\left(83^{\circ} 49^{\prime} \mathrm{W}, 9^{\circ} 45^{\prime} \mathrm{N}\right)$, $1500 \mathrm{~m}$ elevation, forest litter, berlese, 1 female, 4.6.1997, leg. R. Anderson \#CR1A97 001G (KNHM); La Selva, Field Sta., Puerto Viejo de Sarapiqui, Rio Puerto Viejo, $\left(83^{\circ} 59^{\prime} \mathrm{W}, 10^{\circ} 26^{\prime} \mathrm{N}\right)$, Berlese, epiphytic root fibers, cups, axils, 2 males, 1 female, 5.-11.3.1973, leg. J. Wagner \& J. Kethley (FMNH); Cartago, Ref. Nac. de Fauna Silvestre Tapanti, $2.5 \mathrm{~km}$ E Station $\left(83^{\circ} 46.82^{\prime} \mathrm{W}, 9^{\circ} 44.23^{\prime} \mathrm{N}\right)$, $1330 \mathrm{~m}$ elevation, collected by flight intercept trap, 2 females, 30.10.-1.11.2001, leg. R. Brooks \#CR1B01 16 (KNHM); $10 \mathrm{~km} \mathrm{~S}$ Tapanati, Rio Grande de Orosi $\left(83^{\circ} 47^{\prime} \mathrm{W}, 9^{\circ} 42^{\prime} \mathrm{N}\right), 1500 \mathrm{~m}$ elev., Berlese, litter conc. moss on logs and loam, male, 14.4.1973, leg. J. Wagner \& J. Kethley (FMNH); San José, La Hondura, Rio Claro $\left(83^{\circ} 58^{\prime} \mathrm{W}, 10^{\circ} 3^{\prime} \mathrm{N}\right), 1150 \mathrm{~m}$ elev., Berlese, epiphyte duff on log next to Rio Claro, 1 male, 3 females, 5.4.1973, leg. J. Wagner \& J. Kethley (FMNH); same Prov., 1 male, 2 females, 1935, 1936, 1937, leg. A. Bierig (FMNH); Alajuela, E.B. San Ramón, R.B. San Ramón, 27 km N \& 8 km W San Ramón $\left(84^{\circ} 35.30^{\prime} \mathrm{W}, 10^{\circ} 13.30^{\prime} \mathrm{N}\right), 950 \mathrm{~m}$ elevation, forest litter, berlese, 1 male, 1 female, 15.6.1997, leg. R. Anderson \#CR1A97 015B (KNHM); same location, $810 \mathrm{~m}$ elevation, collected by flight intercept trap, 4 females, 8.7.2000, female collected from treefall litter, 7.7.2000, leg. J. Ashe, R. Books, Z. Falin, \#CR1ABF00 084 (KNHM); same location, wet montane forest litter, 1120 m elevation, female, 29.6.-6.7.1999, leg. R. Anderson \#CR1A99-109D (KNHM); Alajuela, Rio Peñas Blancas $\left(84^{\circ} 43^{\prime} \mathrm{W}, 10^{\circ} 19^{\prime} \mathrm{N}\right)$, wet forest, sifted litter, $800 \mathrm{~m}$ elevation, female, 27.4.1988, leg. J. Longino \#2015-5 (KNHM); same location, $875 \mathrm{~m}$ elevation, collected by flight intercept trap, 2 females, 19.5.1989, leg. J. Ashe, R. Brooks, R. Leschen, \#267 (KNHM); Puntarenas, Las Cruces, Biol. Sta., San Vito, $5 \mathrm{~km}$ SW $\left(82^{\circ} 59.18^{\prime} \mathrm{W}\right.$, $\left.8^{\circ} 46.59^{\prime} \mathrm{N}\right), 1425 \mathrm{~m}$ elevation, leaf litter, berlese, male, 22.6.1998, leg. R. Anderson \#CR1A98 108 (KNHM); same location, but $\left(82^{\circ} 57.58^{\prime} \mathrm{W}, 8^{\circ} 47.14^{\prime} \mathrm{N}\right), 1330 \mathrm{~m}$ elevation, collected by flight intercept trap, female, 28.-31.5.2004, leg. J.S. Ashe, Z. Falin, I. Hinojosa, \#CR1AFH04 060 (KNHM); same location, OTS station, $4700 \mathrm{ft}$. La Fila, Berlese, logmold, 2 males 2 females, 21.3.1973, leg. J. Wagner \& J. Kethley (FMNH); same location $\left(82^{\circ} 58^{\prime} \mathrm{W}, 8^{\circ} 46^{\prime} \mathrm{N}\right)$, but $4000 \mathrm{ft}$., Berlese, forest floor litter on slope dry, male, 16.3.1973, leg. J. Wagner \& J. Kethley (FMNH); San Vito, Est., Biol. Las Alturas, $1500 \mathrm{~m}$ elevation, female, May 1992, leg. P. Hanson (UIC); Puntarenas, Monte Verde, $1570 \mathrm{~m}$ elevation, leaf \& bark litter, female, 11.5.1989, leg. J. Ashe, R. Brooks, R. Leschen \#142 (KNHM); Chitaría, female, 1943, leg. A. Bierig (FMNH); La Caja, 2 females, 2.4.1940, leg. A. Bierig (FMNH); La Estrella, male, 24.10.1941, leg. A. Bierig (FMNH); Panama: Chiriqui, $5.6 \mathrm{~km} \mathrm{~N}$ Boquete, La Culebra Trail $\left(82^{\circ} 25.18^{\prime} \mathrm{W}, 8^{\circ} 49.23^{\prime} \mathrm{N}\right), 1800 \mathrm{~m}$ elevation, cloud forest litter, male, 15.6.1996, leg. R. Anderson, \#PAN2A96 96-131A (KNHM); $5.7 \mathrm{~km} \mathrm{~N}$ Boquete $\left(82^{\circ} 26.0^{\prime} \mathrm{W}, 8^{\circ} 48.0^{\prime} \mathrm{N}\right), 1500 \mathrm{~m}$ elevation, oak forest litter, 2 females, 19.6.1995, leg. R. Anderson, \#PAN2A95 35C (1 KNHM, 1 UIC); Chiriqui, $20 \mathrm{~km} \mathrm{~N}$ Gualaca, Finca La Suiza $\left(82^{\circ} 12^{\prime} \mathrm{W}, 8^{\circ} 39^{\prime} \mathrm{N}\right), 1450-1600 \mathrm{~m}$ elevation, oak forest litter, 2 females, 11.7.1995, leg. R. Anderson \#PAN2A95 18B (KNHM); Coclé, $7.2 \mathrm{~km} \mathrm{NE} \mathrm{El} \mathrm{Cope}$ $\left(80^{\circ} 35^{\prime} \mathrm{W}, 8^{\circ} 37^{\prime} \mathrm{N}\right), 750 \mathrm{~m}$ elevation, forest litter, berlese, male, 7.7.1995, leg. R. Anderson \#PAN2A95 07 (KNHM); Coclé, $7.2 \mathrm{~km}$ NE Copé $\left(8^{\circ} 37^{\prime} \mathrm{N}, 80^{\circ} 35^{\prime} \mathrm{W}\right), 730 \mathrm{~m}$ elev., flight intecept trap, female, 20.5.-7.6.1995, leg. J. Ashe \& R. Brooks \#140 (KNHM); Chiriqui Prov., NW Volcan $\left(8^{\circ} 49.16^{\prime} \mathrm{N}, 82^{\circ} 40.26^{\prime} \mathrm{W}\right)$, litter near stream, $1410 \mathrm{~m}$ elev., female, 17.5.2001, leg. L. Herman \& W. Opitz (AMNH); Qda. los Caidos, Cerro Colorado, $1200 \mathrm{~m}$ elev., litter at tree fern nr. water fall, litter small quebrada, buttressed tree, litter at log, 4 males, 4 females, 6.1.1981, leg. W. Suter (7 FMNH, 1 UIC); Finca Lerida, nr. Boquete, $5650 \mathrm{ft}$. elev., forest floor litter, 2 females, 14.3.1959, leg. H.S. Dybas (FMNH); $24 \mathrm{~km} \mathrm{~W} \mathrm{El} \mathrm{Hato} \mathrm{del} \mathrm{Volcan,}$ $3800 \mathrm{ft}$. elev., Berlese, cloud forest litter, 2 males, 1 female, 26.-27.6.1976, leg. A. Newton (2 FMNH, 1 UIC); 3.5 km E Escopeta $\left(81^{\circ} 50^{\prime} \mathrm{W}, 8^{\circ} 34^{\prime} \mathrm{N}\right), 1856 \mathrm{~m}$ elev., Berlese, litter \& root mat Cerro Bollo cloud forest, 1 male, 3 females, 13.6.1980, leg. J. Wagner (FMNH); El Mirador, Finca Collins, nr. Boquete, $6000 \mathrm{ft}$. elev., Berlese, cloud forest litter, female, 25.6.1976, leg. A. Newton (FMNH); Bocas del Toro, Almirante, floor litter, 1 male, 2 females, 27.3.1959, leg. H.S. Dybas (FMNH); Cerro Colorado, Qda., 3w, 1490 m elev., conc. of woody slash, small clearing, male, 11.1.1981, leg. W. Suter (FMNH); trail to Cerro Colorado peak, $1475 \mathrm{~m}$ elev., litter at stump, 28.1.1981, leg. W. Suter (FMNH); Cerro Colorado, Qda. Gato, $1345 \mathrm{~m}$ elev., log, fern trunk core on rdside, 2 females, 21.1.1981, leg. W. Suter (FMNH); same location, but moss on strap fern rhizome, ecotonal slash and bamboo litter, $1290 \mathrm{~m}$ elev., 2 females, 17.1.1981, leg. W. Suter (FMNH); same location, E side, 1175 m elev., gully litter, oak fringe, male, 27.1.1981, leg. W. Suter (FMNH); same location, $1290 \mathrm{~m}$ elev., grassy ecotonal debris, female, 10.1.1981, leg. W. Suter (FMNH); same location, but E side, $1175 \mathrm{~m}$ elev., epiphytes on mossy log, gully litter, oak fringe, 1 male, 3 females, 27.1.1981, leg. W. Suter (FMNH); same location (W), Qda. lw., $1450 \mathrm{~m}$ elev., debris on forest slope, 8.1.1981, leg. W. Suter (FMNH); same location, but $1290 \mathrm{~m}$ elev., butress tree hole, 14.1.1981, leg. W. Suter (FMNH); same location, but 
Qda.3w., litter along path on slope, male, $1490 \mathrm{~m}$ elev., 24.1.1981, leg. W. Suter (FMNH); same location, but floor litter pocket nr. tree, 1 male, 1 female, 10.1.1981, leg. W. Suter (FMNH); $25 \mathrm{~km}$ NNE San Felix (81 $50^{\circ} \mathrm{W}$, $\left.8^{\circ} 34^{\prime} \mathrm{N}\right)$, Berlese, epiphytic soil-root mat on log Quebrada, Alicia cloud forest, 2 males, 1 female, 17.6.1980, leg. J. Wagner (FMNH); pipeline road $1 \mathrm{~km} \mathrm{~N}$ jct. Fortuna/ Chiriqui Grande road $\left(82^{\circ} 10^{\prime} \mathrm{W}, 8^{\circ} 53^{\prime} \mathrm{N}\right), 300 \mathrm{~m}$ elev., tropical wet forest litter, sifting, female, 28.-30.7.1987, leg. D.M. Olson (FMNH); same location $\left(82^{\circ} 13^{\prime} \mathrm{W}\right.$, $8^{\circ} 47^{\prime} \mathrm{N}$ ), but $1250 \mathrm{~m}$ elev., Sandero Divisa, premontane rain forest litter, sifting, 2 females, 9.-11.7.1987, leg. D.M. Olson (FMNH); same location $\left(82^{\circ} 11^{\prime} \mathrm{W}, 8^{\circ} 47^{\prime} \mathrm{N}\right)$, tropical wet forest litter, sifting, female, 16.-18.7.1987, leg. D.M. Olson (FMNH); Colombia: Valle del Cauca, PNN Farallones del Cali, Anchicaya $\left(76^{\circ} 48^{\prime} \mathrm{W}, 3^{\circ} 26^{\prime} \mathrm{N}\right)$, 900 m elevation, Malaise, male, 3.-17.7.2001, leg. S. Sarria \#M2834 (KNHM); same location, but Cgto. La Meseta $\left(76^{\circ} 40^{\prime} \mathrm{W}, 3^{\circ} 34^{\prime} \mathrm{N}\right), 2200 \mathrm{~m}$ elevation, female, 27.8.10.9.2003, leg. S. Sarria, M. Losso \#M4570 (KNHM); Nariño, R.N. La Planada, Via Hondón $\left(1^{\circ} 15^{\prime} \mathrm{N}, 78^{\circ} 15^{\prime} \mathrm{W}\right)$, 1930 m elev., Red., female, 9.8.-12.8.2004, leg. D. Arias \#M4897 (KNHM); Vaupés, Estación Biologica MosiroItajura (Caparú) $\left(1^{\circ} 4 \mathrm{~S}\right.$, $\left.69^{\circ} 31^{\prime} \mathrm{W}\right)$, Igapo, Malaise trap, male, 1.-9.2.2003, leg. J. Pinzón \#M3637 (KNHM); Ecuador: Zamora-Chinchipe, Rio Bambuscaro (7859.0'W, $4^{\circ} 7.0$ 'S), flight intercept trap, female, 26.-4.7.1996, leg. P. Hibbs, \#ECU1H96 001 (KNHM); Pichincha, Macquipucuna Biological Station $\left(0^{\circ} 7.12^{\prime} \mathrm{N}, 78^{\circ} 37.48^{\prime} \mathrm{W}\right)$, malaise trap, female, 24.2.-2.3.1996, leg. P. Hibbs \#ECU2H96008A (KNHM); Sucumbios, Sacha Lodge $\left(0.5^{\circ} \mathrm{S}, 76.6^{\circ} \mathrm{W}\right), 270 \mathrm{~m}$ elev., malaise trap, 2 females, 4.-14.3.1994, leg. Hibbs (KNHM); Pichincha, 17 km SE St. Domingo de Colorados, Tinalandia, foliage, $3000 \mathrm{ft}$. elev., 3 males, 4 females, 16.-21.10.1988, leg. L. Herman (6 AMNH, 1 UIC); W of Alluriquin, Tinalandia, 2600$2800 \mathrm{ft}$. elev., litter nr. stream, 3 females, 19.-20.5.1993, leg. L. Herman \#2724-2725 (AMNH); 18-20 km NE Alluriquin, old Quito - Sto. Domingo rd., litter, 4700$4900 \mathrm{ft}$. elev., female, 21.10.1988, leg. L. Herman (AMNH); Peru: Loreto Prov., Iquitos, $90 \mathrm{~m}$ elev., flight intercept trap, 1 male, 1 female, 9.5.1992, leg. J. DanoffBerg (KNHM).

Diagnosis: $D$. schuelkei is one of the largest species of the genus Dichous. It is totally black with long narrow head. In particular, the characteristic shape of the paramere cannot be confused with other Diochus species.

Description: Length: $5.1 \mathrm{~mm}$. Colouration: unicoloured black.

Head $0.76 \mathrm{~mm}$ long, $0.56 \mathrm{~mm}$ wide; slightly divergent to posterior margin; eyes not prominent; small; temples more than three times as long as eyes; EL : HL 0.21; temples divergent posteriad; PW : EW 1.15; posterior angles widely rounded; posterior margin convex; neck width less than one third of head's width; setiferous punctation deep and moderately dense; adjacent to wide impunctate midline with longitudinal row of four to five punctures; posterior vertex with few setiferous punctures; laterad to medial rows two further irregular rows of about five punctures; transverse microsculpture weak, but distinct; surface slightly shiny.

Antenna nearly as long as head and half of pronotum combined; three basal antennomeres conical; first slightly thicker and longer than second and third antennomere; second and third antennomeres nearly twice as long as apical width; fourth antennomere slightly longer than wide; fifth approximately quadrate; following antennomeres one fourth wider than long; all antennomeres pubescent; basal antennomeres with few long setae.

Pronotum $0.85 \mathrm{~mm}$ long, $0.66 \mathrm{~mm}$ wide; sides parallel; anterior angles widely rounded; posterior angles slightly shorter rounded; lateral margin fine; in dorsal aspect, visible in posterior half; setiferous punctation deep and sparse; adjacent to impunctate midline with row of four punctures; interstice between first pair twice as wide as between two posterior pairs; irregular number of punctures laterad to medial row of punctures; ranging between four and five; along lateral margin several setiferous punctures; on disc with sparse micro-punctation; without microsculpture; surface polished.

Elytra $0.90 \mathrm{~mm}$ long, $0.90 \mathrm{~mm}$ wide; sides divergent to posterior angles; shoulders obtusely angulate; posterior angles obtuse; posterior margin slightly emarginate; setiferous punctation moderately dense and deep; on average, interstices between punctures as wide as diameter of punctures; weak coriaceous ground sculpture; surface less shiny than that of pronotum.

Abdomen densely pubescent.

Aedeagus with thick seminal vesical; slightly longer than half of total length of central lobe; basal inner duct looped; with funnel-like widening; ending in winged sclerotised forceps; apical filamentous duct with long coil; paramere projecting central lobe; continuously widened to apex; apex at outer side with long triangular process pointing to apex; slender apex with four long setae; shaft with numerous sensillae.

Spermatheca $0.83 \mathrm{~mm}$ long, $0.31 \mathrm{~mm}$ wide; bursa copulatrix in central position of elongate coiled duct; coiled duct oval; widest at middle; sides of each narrowed end nearly parallel; evenly rounded at both ends.

Etymology: The species name honours the collector Manfred Schülke, who extensively collected Staphylinidae in Costa Rica during several trips.

\section{Diochus tricolor spec. nov.

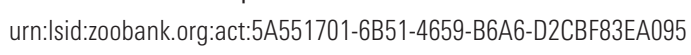 Figs 13A-C; 39C, 43B}

Type material: male, Holotype: Brazil: Mato Grosso, $40 \mathrm{~km}$ S Poconé, Rio Clarinho (51 $\left.{ }^{\circ} 43.37^{\prime} \mathrm{W}, 16^{\circ} 36.38^{\prime} \mathrm{S}\right)$, decay fruit, 15.3.2013, leg. U. Irmler (UFMT). 
Paratypes: 1 male, 1 female, with same data as holotype (UIC); Peru: Madre de Dios, Dept., Tambopata, litter at swamp edge, 4 females, 28.10.1982, leg. L.E. Watrous \& G. Mazurek (FMNH).

Diagnosis: The species is characterised by the black head in contrast to the light yellow pronotum and the slightly darker elytra. It is the smallest species of the group. It can be separated from the similarly small $D$. antennalis by the colouration: $D$. tricolor with black head, $D$. antennalis totally light yellow. The funnel-like widening of the basal inner duct and the presence of an apical filamentous duct show that it belongs to the D. inornatus-group. In contrast to the slightly apically widened paramere of $D$. antennalis, the paramere of D. tricolor is more slender.

Description: Length: $2.9 \mathrm{~mm}$. Colouration: head black; pronotum yellow, elytra yellowish brown; abdomen brown; legs and antennomeres one to three yellow; four to eleven dark.

Head: $0.43 \mathrm{~mm}$ long, $0.36 \mathrm{~mm}$ wide; eyes slightly prominent; temples twice as long as eyes; $\mathrm{EL}: \mathrm{HL}=0.25$; temples distinctly divergent posteriad; $\mathrm{PW}: \mathrm{EW}=1.24$; neck one third as wide as head at posterior angles; posterior angles shortly rounded; posterior margin slightly convex; setiferous punctation sparse; on vertex, four setiferous punctures in convergent line adjacent to impunctate midline; laterad two additional supraocular lines of setiferous punctures; temples and posterior margin more densely punctate; without microsculpture; surface polished.

Antennae slightly longer than head; first antennomere elongate; slightly longer than two following antennomeres; conical second and third antennomere elongate; approximately twice as long as apical width; fourth antennomere slightly longer than wide; width of following antennomeres slightly increasing; fifth antennomere slightly wider than long; tenth antennomere 1.5 times as wide as long; all antennomeres pubescent with apical setae.

Pronotum: $0.48 \mathrm{~mm}$ long, $0.39 \mathrm{~mm}$ wide; sides nearly parallel; anterior angles widely rounded; anterior margin semi-circular; posterior angles shortly rounded; lateral margin fine; in dorsal aspect, visible in posterior half; setiferous punctation sparse; along wide impunctate midline three pairs of setiferous punctures; interstice between anterior pair twice as wide as interstices between two posterior pairs; few additional punctures laterad; several punctures with long setae along lateral margin; without microsculpture; surface polished.

Elytra: $0.51 \mathrm{~mm}$ long, $0.54 \mathrm{~mm}$ wide; sides slightly divergent to posterior angles; at posterior angles 1.3 times as wide as at shoulders; shoulders obtuse; posterior margin triangularly emarginate; setiferous punctation in irreg- ular lines of fife to six punctures; three lines on disc; additional line along lateral margin.

Abdomen densely pubescent.

Aedeagus moderately broad; seminal vesical half as long as central lobe; basal inner duct looped; ending in funnel-like widening; apical inner duct shortly coiled; paramere slender; slightly shorter than central lobe; slightly widened at apex to small circular plate; at apex with four long setae; three sensillae at central shaft.

Spermatheca: $0.21 \mathrm{~mm}$ long, $0.12 \mathrm{~mm}$ wide; bursa copulatrix in asymmetric position to coiled duct; coiled duct with few irregular coils.

Etymology: The species name derived from the same Latin word meaning three colours and refers to the threecoloured fore-body.

\section{Diochus vicinus SHARP, 1876 \\ Figs 10A-C, 39D, 43C}

Diochus vicinus SHARP, 1876: 185

Diochus flavicans SHARP, 1876: 185 new synonymy

Type material examined: 1 female, Brazil: Pará, Tapajos (BMNH); 2 female syntypes of $D$. flavicans, Brazil: Pará, Tapajos (BMNH).

Further material examined: Colombia: Vichada, PNN El Tuparro, Cerro Tomás $\left(67^{\circ} 51^{\prime} \mathrm{W}, 5^{\circ} 21^{\prime} \mathrm{N}\right), 140 \mathrm{~m}$ elev., Malaise trap, male, 22.5.-3.6.2001, leg. I. Gill (KNHM); Brazil: Amazonas, Ilha de Marchanteria ( $59^{\circ} 58^{\prime} \mathrm{W}, 3^{\circ} 15^{\prime} \mathrm{S}$ ), Varzéa, floating meadow, 3 males, 16.2.1982, 22.1.1982, leg. J. Adis (UIC); Ilha Muratú $\left(60^{\circ} 21^{\prime} \mathrm{W}, 3^{\circ} 34^{\prime} \mathrm{S}\right)$, 2 females, 25.2.1975, leg. U. Irmler (UIC); Roraima, mouth of Rio Branco, Lago Adauaú (6151'W, $1^{\circ} 19^{\prime} \mathrm{S}$ ), male, 22.8.1971, leg. U. Irmler (UIC); Pará, $5 \mathrm{~km} \mathrm{E}$ Belém, soil litter layer, in primary terra firme forest, male, 30.5.1973, leg. R.T. Schuh (AMNH); IPEAN, from litter in "Mocambo", male, 3.7.1973, leg. R.T. Schuh (AMNH); Mato Grosso, Barra de Tapirapé, at light, 4 males, 1 female, 15.12.1960, leg. B. Malkin (FMNH); male, same location, same collector, but 1.-11.1.1963 (FMNH); Peru: Loreto, Lake Yarinachocha, $10 \mathrm{~km}$ NW Pucallpa, $150 \mathrm{~m}$ elev., collected at light, male, 27.12.1971, leg. R.T. Schuh (AMNH); Madre de Dios, Tambopata, male, 26.10.1982, leg. L.E. Watrous, G. Mazurek (FMNH).

Diagnosis: In size, colouration and length of antennae, $D$. vicinus resembles D. inornatus and D. hanagarthi. The EL : HL is 0.24 , slightly shorter than in D. hanagarthi, separates both species from D. inornatus with longer temples $(\mathrm{EL}: \mathrm{HL}=0.21)$. Moreover, the antennae are slightly longer than in D. hanagarthi and D. inornatus. The species can be easily separated from the other Diochus species by the elongate hooked apical process of the paramere. Unfortunately, the two syntypes of $D$. flavi- 
cans are females. As I found no significant differences to $D$. vicinus, $D$. flavicans is synonymised to $D$. vicinus.

Description: Length: $4.3 \mathrm{~mm}$. Colouration: head and pronotum totally yellow-brown; elytra light brown with dark transverse spot in anterior half on each side of suture; abdomen darker than fore-body, but posterior margin of segments as light elytra; legs yellow; antennomeres 1, 2, and 11 yellow; antennomeres 4-10 darker, brown.

Head: $0.46 \mathrm{~mm}$ long, $0.40 \mathrm{~mm}$ wide; eyes slightly prominent; moderately large; temples 2.5 times as long as eyes; $\mathrm{EL}: \mathrm{HL}=0.24$; temples slightly divergent posteriad; PW : EW 1.14; posterior angles nearly rectangular; sharply rounded; clypeus widely rounded; neck one third as wide as head; inter-ocular space and clypeus densely and deeply punctate; wide midline impunctate; on average, interstice between punctures as wide as or slightly shorter than diameter of setiferous punctures; on average, setae distinctly longer than interstices; on vertex sparsely punctate; large area without punctures; laterad densely punctate; surface without microsculpture; shiny.

Antennae slightly longer than head and half of pronotum combined; first to third antennomere distinctly longer than following antennomeres; nearly twice as long as wide; fourth to eleventh antennomeres approximately quadrate; first antennomere with long thick setae; fourth to eleventh antennomere pubescent;

Pronotum: $0.54 \mathrm{~mm}$ long, $0.49 \mathrm{~mm}$ wide; widest close to posterior margin; slightly narrowed to anterior margin, but nearly parallel; posterior and anterior angles widely rounded; sides finely margined; in dorsal aspect, margin covered in anterior half; setiferous punctures large, but sparse; on average, interstices between punctures twice as wide as diameter of punctures; on each side of impunctate midline with 3-4 setiferous punctures in longitudinal line; without microsculpture, but indistinct extremely weak ground sculpture; surface shiny.

Elytra: $0.67 \mathrm{~mm}$ long, $0.67 \mathrm{~mm}$ wide; sides divergent to posterior margin; posterior angles and shoulders widely rounded; shoulders obtuse; setiferous punctures in longitudinal lines; setae pointing posteriad; interstices between punctures of lines and between lines at least two to three times as wide as diameter of punctures; surface with indistinct weak ground sculpture; shiny.

Abdomen densely pubescent and matt in contrast to fore-body.

Aedeagus with seminal vesical slightly longer than half of total length of central lobe; basal inner duct looped; apical inner duct with large coil; paramere narrow at base; slightly widened to apex; not projecting apex of central lobe; with long asymmetric acute process at apex with short apical hook.

Spermatheca $0.47 \mathrm{~mm}$ long, $0.21 \mathrm{~mm}$ wide; bursa copulatrix in central position of coiled oval duct; coiled duct widest in anterior half; narrowed at middle and slightly widened in posterior half.

\section{Diochus maculicollis-group}

\section{Diochus brooksi spec. nov.}

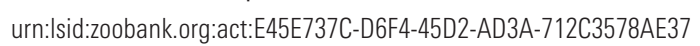

Figs 20A-C, 39E, 43D

Type material: male, Holotype: Venezuela: Aragua, Rancho Grande, Biol. Stn. $\left(10^{\circ} 21^{\prime} \mathrm{N}, 67^{\circ} 41^{\prime} \mathrm{W}\right), 1115 \mathrm{~m}$ elev., along stream, 8.3.1995, leg. R. Brooks, \#062 (KNHM).

Paratypes: Panama: Chiriqui Prov., Cerro Colorado, $1220 \mathrm{~m}$ elev., buttress with log, 3 females, litter u. small clump of bamboo-like grass, 1 male, 1 female, 5.1.1981, leg. W. Suter (FMNH); same location, but $1290 \mathrm{~m}$ elev., 6 males, 3 females, litter small quebrada, 2 females, litter under Agave-like herb, 2 males, 1 female, litter at log, semidry, 1 female, grassy litter with fern, 6.1.1981, leg. W. Suter (13 FMNH, 2 UIC); same location, but $1220 \mathrm{~m}$ elev., under bamboo, 3 males, 7 females, 7.1.1981, leg. W. Suter (FMNH); same location, but stage IV stump, passalid borrows, 7 females, 8.1.1981, leg. W. Suter (FMNH); same location collector and date, but $1200 \mathrm{~m}$ elev., camp, grass litter on slope under bush, male, (FMNH); same location collector and date, but $1450 \mathrm{~m}$ elev., flank Qda., buttress of large tree along slope, male, (FMNH); same location, but $1290 \mathrm{~m}$ elev, litter in depression, 4 males, 5 females, tree buttress, 1 male, 6 females, litter at log, 1 male, 3 females, floor litter pocket nr. tree, 4 females, grassy ecotonal debris, male, 10.1.1981, leg. W. Suter (21 FMNH, 1 UIC); same location, but $1220 \mathrm{~m}$ elev., semi-dry slash, small clearing, 3 males, 2 females, 12.1.1981, leg. W. Suter (FMNH); same location and elev., but wet basal pseudo-fork between small trees, male, litter of stage III stump, semidry, 3 males, 8 females, 13.1.1981, leg. W. Suter (FMNH); same location, $1290 \mathrm{~m}$ elev., buttress tree hole, 1 male, 5 females, 14.1.1981, leg. W. Suter (FMNH); same location, but $1225 \mathrm{~m}$ elev., litter at semi-exposed log abv. rd., 3 males, stump with Passalidae, female, 15.1.1981, leg. W. Suter (FMNH); same location, but $1290 \mathrm{~m}$ elev., litter at buttress under lily, 2 males, 11 females, moss on strap fern rhizome, female, 17.1.1981, leg. W. Suter (FMNH); same location, but $1235 \mathrm{~m}$ elv., stump with ant nest, 2 males, 1 female, litter u. cut twig pile in small hillside clearing, 2 males, stage $\mathrm{V}$ log, 1 male, 1 female, 23.1.1981 (FMNH); same location, but $1210 \mathrm{~m}$ elev., litter u. rdside bushes, female, 25.1.1981, leg. W. Suter (FMNH); same location, but drill site, $1210 \mathrm{~m}$ elev., litter at rdside under bush, 2 males, 24.1.1981, leg. W. Suter (FMNH); same location, but $1210 \mathrm{~m}$ elev., litter u. rdside bushes, female, 25.1.1981, leg. W. Suter (FMNH); same location, but $1290 \mathrm{~m}$ elev., buttress of small tree on slope, 2 females, litter at log, litter pocket, female, edge of wds, 5 males, 4 females, $1235 \mathrm{~m}$ elev., buttress treehole oak?, male, under seedling banana, female, 26.1.1981, leg. W. Suter (12 FMNH, 1 UIC); same location, but $1175 \mathrm{~m}$ elev., E side, gully litter, oak fringe, 2 males, 5 females, 27.1.1981, leg. W. Suter (FMNH); Cocle Prov., El Valle, $2400 \mathrm{ft}$. elev., floor debris stream 
bed, male, 23.2.1959, leg. H.S. Dybas (FMNH); Chiriqui Prov., Boquete, sifted, coffee tree litter, male, 2.10.1975, leg. D.S. Chandler (FMNH); Canal Zone, Barro Colorado Il., Fairchild Trail, bark \& under bark debris, same fallen tree as \#171, female, 28.1.1959, leg. H.S. Dybas (FMNH); Cerro Campana, Berlese, cloud forest leaf litter, 1 male, 1 female, 14., 23.2.1976, leg. A. Newton (FMNH); Bocas del Toro Prov, Cerro Colorado, Qda. 3w, off hwy. 17, grassy litter, pathside clearing, $1490 \mathrm{~m}$ elev., 2 females, 11.1.1981, leg. W. Suter (FMNH); Venezuela: same location and data as holotype, 1 male, 1 female, (1 KNHM, 1 UIC); same location, 1140 m elevation, flight intercept trap, male, 25.-28.2.1995, leg. R. Brooks, \#011 (KNHM); same location, 1390-1420 m elevation, berlese leaf litter, female, 27.2.1995, leg. R. Brooks, \#004 (KNHM); same location and same collector, but $1115 \mathrm{~m}$ elevation, along stream, 1 male, 1 female, 8.3.1995, leg. R. Brooks \#062, \#063 (UIC); Columbia: Meta Dept. 23 km NW Villavicencio, Quebrada Susumuko, $1000 \mathrm{~m}$ elev., forest litter, male, 5.3.1972, leg. S. \& J. Peck (FMNH).

Diagnosis: Regarding the black colouration D. brooksi closely resembles $D$. ecuadoriensis within the D. maculicollis-group. It is distinguished from $D$. ecuadoriensis by the quadrate head and, in particular, by the slender curved paramere with three setae on the outer edge of the apex. From the similarly sized $D$. maculicollis, D. brooksi can be separated by the black head and pronotum.

Description: Length: $3.2 \mathrm{~mm}$. Colouration: unicoloured black; legs and antennae yellow; medial antennomeres brownish; antennomeres four and five darker than six to ten.

Head $0.45 \mathrm{~mm}$ long, $0.41 \mathrm{~mm}$ wide; eyes slightly prominent; large; at least half as long as temples; EL : $\mathrm{HL}=0.27$; temples slightly divergent to posterior margin; $\mathrm{PW}: \mathrm{EW}=1.12$; posterior margin widely convex; neck one third as wide as head width's; setiferous punctation deep and moderately sparse; clypeus more densely punctate than vertex; vertex with impunctate midline; adjacent to midline row of four punctures; convergent posteriad; interstice between anterior pair one fourth wider than between posterior pair close to neck; laterad to medial row of punctures another irregular row of punctures; postocular area densely punctate; microsculpture weak; transversely reticulate; surface slightly shiny.

Antennae as long as head and one third of pronotum combined; first antennomere thick; antennomeres two and three conical; slightly narrower and shorter than first; one fourth longer than apical width; following antennomeres wider than long; fourth nearly quadrate; ninth twice as wide as long; all antennomeres pubescent; basal antennomeres with few setae.

Pronotum $0.61 \mathrm{~mm}$ long, $0.48 \mathrm{~mm}$ wide; sides nearly parallel; anterior angles widely rounded; posterior angles rounded but slightly more angulate than anterior angles; lateral margin fine; in dorsal aspect, visible in poste- rior half; setiferous punctation as deep as on head, but sparser; wide midline impunctate; adjacent to midline with row of three punctures; interstice between anterior pair of punctures more than twice as wide than between posterior pairs of punctures; laterad to medial row of punctures three to four punctures; along lateral margin several setiferous punctures; without microsculpture; surface polished.

Elytra $0.63 \mathrm{~mm}$ long, $0.61 \mathrm{~mm}$ wide; shoulders obtusely angled; sides divergent to posterior margin; posterior margin concave; setiferous punctation in irregular rows of five to six punctures; between rows of setiferous punctures with finer and sparse punctation.

Abdomen densely pubescent.

Aedeagus slender; seminal vesical of endophallus elongate; nearly two third as long as central lobe; basal inner duct looped; ending in complex sclerotised structure; slender paramere not projecting central lobe; not widened to apex; apical half curved and with three long setae at outer side; three sensillae at outer side of shaft.

Spermatheca $0.21 \mathrm{~mm}$ long, $0.21 \mathrm{~mm}$ wide; bursa copulatrix in marginal or lateral position to coiled duct; coiled duct nearly circular, but irregularly coiled.

Etymology: The species is named to honour the collector of the species, Richard Brook, who collected extensively Staphylinidae in the Neotropical region.

\section{Diochus ecuadoriensis spec. nov.

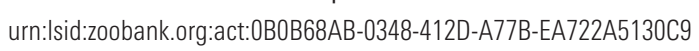 Figs 21A-C, 39F, 43E}

Type material: male, Holotype: Ecuador: Pichincha, Macquipucuna Station, 45 km NW Quito, 1600-1650 m elevation, Epiphyte litter, berlese, guava grove, 14.4.1990, leg. C. Carlton \& R. Adarve (KNHM).

Paratypes: 1 female with same data as holotype (KNHM); same location, $50 \mathrm{~km}$ NW Quito, $1350 \mathrm{~m}$ elevation, epiphyte berlesate, 1 male, 2 females, 20.12.1991, leg. C. Carlton \& R. Leschen (KNHM, UIC); same location, same collector, $1650 \mathrm{~m}$ elevation, male, 21.12.1991 (UIC); same location, $\mathrm{N}$ of field station, substrate berlesate, female, 20.12.1991, leg. C. Carlton (KNHM); Napo Reg., Tiputini Res. Stat. ( $\left.0^{\circ} 38^{\prime} \mathrm{S}, 76^{\circ} 09^{\prime} \mathrm{W}\right), 220 \mathrm{~m}$ elev., flight intercept trap, 1 male, 1 female, 5.-25.9.2000, leg. D.J. Inward \& K.A. Jackson \# 2000-194 (BMNH); Napo Prov., Baeza, near Rio Papallacta, $5800 \mathrm{ft}$. elev., litter near stream, male, 28.5.1993, leg. L. Herman (AMNH); Napo Prov., $69 \mathrm{~km}$ NE Baeza, $15 \mathrm{~km}$ SW Reventador, litter, $4600 \mathrm{ft}$. elev., male, 28.-30.10.1988, leg. L. Herman (AMNH); Napo Prov., 15.6 km W of Baeza-El Chaco jct., on road to El Chaco, $7600 \mathrm{ft}$. elev., 2 females, 30.5.1993, leg. L. Herman \#2761 (AMNH); Pichincha, Las Palmeras, old Quito Sto. Domingo Rd., km 59, 43 km NE Alluriquin, litter, $6400 \mathrm{ft}$. elev., 1 female, 23.10.1988, leg. L. Herman (AMNH); Pichincha, 17 km SE Sto. Domingo 
de Colorados, Tinalandia, litter, $3000 \mathrm{ft}$. elev., 2 females, 16.-21.10.1988, leg. L. Herman (AMNH).

Diagnosis: The species resembles D. brooksi and D. maculicollis by the bicoloured antennae. It can be easily distinguished from D. maculicollis by the dark blackish head and pronotum. D. ecuadoriensis mostly resembles $D$. brooksi in the dark blackish colour. The head of D.ecuadoriensis is much more elongate and with much denser microsculpture than in D. brooksi. It is nearly 1.4 times as long as wide, whereas it is nearly quadrate in D. brooksi. The aedeagi of the three species are very similar regarding the curved paramere clasping the central lobe. The parameres of $D$. ecuadoriensis have a central triangular process and in this respect, it resembles the paramere of $D$. maculicollis. However, the three long setae on the outer edge of the apical half are in a similar position as in D. brooksi and different from the shorter setae of $D$. maculicollis.

Description: Length: $3.5 \mathrm{~mm}$. Colouration: unicoloured black; legs and antennae light brown; first to third antennomere light brown; fourth to seventh antennomere blackish; eighth light brown; ninth still lighter, dark yellowish; tenth yellow; last antennomere light yellow; lightened to apex.

Head: $0.56 \mathrm{~mm}$ long, $0.41 \mathrm{~mm}$ wide; eyes slightly prominent; $\mathrm{EL}: \mathrm{HL}=0.28$; temples 1.6 times as long as eyes; nearly parallel; $\mathrm{PW}: \mathrm{EW}=1.07$; posterior angles shortly rounded; posterior margin approximately straight; setiferous punctation on clypeus and interocular area denser than on vertex; on average, interstices as wide as diameter of punctures; except on irregularly impunctate midline; on vertex with wide impunctate midline; temples with denser punctation; isodiametric microsculpture dense and deep; surface slightly shiny.

Antennae as long as head and half of pronotum combined; first antennomere thicker than two following antennomeres; second and third antennomere elongate; second more than twice as long as wide; third antennomere 1.3 times as long as apical width; following antennomeres shorter and decreasing in length; fourth approximately quadrate; tenth wider than long; all antennomeres pubescent and with apical setae.

Pronotum $0.62 \mathrm{~mm}$ long, $0.57 \mathrm{~mm}$ wide; sides approximately parallel; in anterior third widely rounded; posterior angles shortly rounded; lateral margin fine; in dorsal aspect, visible in posterior half; setiferous punctation sparse; three pairs of punctures along wide impunctate midline; interstice between anterior pair of punctures more than twice as wide as between posterior two pairs; laterad with few additional punctures; along lateral margin with several setiferous punctures; without microsculpture; surface polished; partly with few micro-punctures.

Elytra $0.71 \mathrm{~mm}$ long, $0.75 \mathrm{~mm}$ wide; shoulders obtusely angulate; sides distinctly divergent to posterior angles; at posterior angles 1.3 times as wide as at shoulders; setiferous punctation in irregular lines of eight to nine punctures; on disc, beside sutural line of punctures, two additional lines; interstices between these lines shorter than between inner line and suture.

Abdomen densely pubescent.

Aedeagus elongate; seminal vesical of endophallus elongate; 0.6 times as long as central lobe; basal inner duct looped; ending in widened sclerotised structure; paramere not projecting central lobe; basal shaft straight and widened at middle to triangular process; apical shaft curved; clapsing central lobe; apex widely rounded and transparent; at upper edge with three long setae; few sensillae at basal shaft.

Spermatheca $0.24 \mathrm{~mm}$ long, $0.15 \mathrm{~mm}$ wide; bursa copulatrix in lateral or marginal position to coiled duct; coiled duct oval with only few coils.

Etymology: The species name derived from the country, where it was found.

\section{Diochus maculicollis FauveL, 1891: 106 Figs 22A-C, 39l, 43F}

Type material examined: 3 syntypes: Venezuela: Caracas, 1 male, without further data (IRSB); 1 male, 1 female, Colonia Tovar, 1.11.1888 leg. E. Simon (IRSB).

Further material examined: Panama: Chiriqui, Cerro Colorado, 1290 m elev., tree buttress, female, 10.1.1981, leg. W. Suter (FMNH); Venezuela: without additional information to location, 3 males, 1858, Moritz, coll. Schaufuss, det. as D. nanus (1 ZMUH, 2 NMW); Pittier National Park, moist forest, wet litter, male, 26.3.1998, leg. C. Schimdt (UIC); Carabobo, Bejuma env. Cerro de Paja $\left(68^{\circ} 14^{\prime} \mathrm{W}, 10^{\circ} 16^{\prime} \mathrm{N}\right), 1400-1500 \mathrm{~m}$ elevation, female, 15.11.2005, leg. V. Brachat (VAC); Caracas, 2 females, without more data, coll. Kraatz (SDEI); Edo. Aragua, $19 \mathrm{~km} \mathrm{~N}$ Maracay, road to Choroni, $1300 \mathrm{~m}$ elev., litter near stream, 3 males, 3 females, 16.4.1994, leg. L. Herman \#2798-2799 (5 AMNH, 1 UIC); same Prov, 18.9 km S Choroni, $2900 \mathrm{ft}$. elev., litter near stream, male, 2.3.1992, leg. L. Herman (AMNH); Ecuador: Napo Prov., $5 \mathrm{~km} \mathrm{~S}$ Baeza on road to Tena, $1700 \mathrm{~m}$ elevation, under rocks and logs, female, 28.4.1990, leg. C. Carlton \& R. Ardave (KNHM); Napo, $33 \mathrm{~km} \mathrm{~N}$ Tena, $59 \mathrm{~km} \mathrm{E}$ on Loreto Road, 2,800 ft. elev., litter on dry slope, male, 4.11.1988, leg. L. Herman (AMNH); Napo Prov., 5.5 km S Baeza, $5800 \mathrm{ft}$. elev., Baeza-Tena rd., litter near stream, female, 28.5.1993, leg. L. Herman \#2751-2765 (AMNH).

Diagnosis: Within the group, D. maculicollis is similarly sized as D. brooksi and D. ecuadoriensis. It can be distinguished from both species by the orange to yellow colouration of the head and pronotum and the lighter antennae. Moreover, the setation of the paramere is different. Whereas D. maculicollis has three short setae, two subapical setae at inner side and one apical seta, 
D. brooksi and D. ecuadoriensis have three long setae at outer edge of paramere.

Description: Length: $3.2 \mathrm{~mm}$. Colouration: yellow; head slightly darker yellow, elytra dark, nearly black; abdomen slightly lighter than elytra; legs yellow; antennomeres 1-3 yellow; 4-7 brown; 8-11 light yellow.

Head: $0.50 \mathrm{~mm}$ long, $0.38 \mathrm{~mm}$ wide; eyes not prominent; large; $\mathrm{EL}: \mathrm{HL}=0.29$; temples 1.5 times as long as eyes; slightly divergent posteriad; $\mathrm{PW}: \mathrm{EW}=1.15$; posterior angles widely rounded; on clypeus, on interocular space and on temples with sparse, but deep setiferous punctures; on clypeus and on interocular space two longitudinal lines with four to five punctures; between inner lines with wide impunctate midline; vertex impunctate; without microsculpture; surface shiny.

Antennae as long as head and half of pronotum combined; antennomeres 1 to 3 elongate; approximately twice as long as wide; first antennomere slightly thicker than following ones and with long thick setae; fourth antennomere quadrate; following antennomeres approximately twice as wide as long; antennomeres four to 11 pubescent.

Pronotum: $0.52 \mathrm{~mm}$ long, $0.46 \mathrm{~mm}$ wide; widest at middle; sides slightly rounded and narrowed to anterior and posterior angles; angles widely rounded; lateral margin fine; in dorsal aspect, covered in anterior half; very sparsely punctate; longitudinal line of three to four setiferous punctures on each side of wide impunctate midline; laterad few more setiferous punctures; without microsculpture; surface shiny.

Elytra: $0.50 \mathrm{~mm}$ long, $0.60 \mathrm{~mm}$ wide; widest at posterior angles; posterior margin triangularly emarginate; continuously divergent from shoulders to posterior angles; shoulders widely rounded; setiferous punctures in longitudinal lines; one line directly adjacent to suture line; three lines on disk and two further lines laterad; indistinct, irregular extremely weak ground-sculpture; less shiny than head and pronotum.

Abdomen densely pubescent and matt in contrast to fore-body.

Aedaegus elongate; seminal vesical of endophallus elongate; approximately two third of total length of central lobe; basal inner duct with short loop in anterior half; paramere with broad basal part and sinuate apical part; in apical half two short setae pointing to inner side; at apex another short seta at outer edge; several sensillae at basal shaft.

Spermatheca irregularly coiled; bursa copulatrix in lateral position to coiled duct.

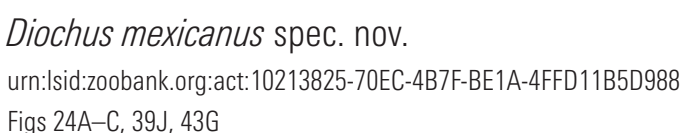

Type material: male, Holotype: Mexico: Veracruz, Fortin, 5.8.1969, leg. S. \& J. Peck (AMNH).
Paratypes: 10 males, 14 females with same data as holotype (22 AMNH, 2 UIC); Veracruz, Balzapote, Berlese, rain forest leaf litter, 2 males, 2 females, 7.8.1976, leg. A. Newton (FMNH); 6 mi NE Catemaco, $1500 \mathrm{ft}$. elev., Berlese, rain forest leaf litter, female, 7.7.1976, leg. A. Newton (FMNH).

Diagnosis: Closely related to D. brooksi regarding the structures of the paramere and the shape of the head. It can be separated from D. brooksi by the shorter elytra. Whereas elytra are nearly quadrate in $D$. brooksi, they are distinctly wider (1.2 times) than long in D. mexicanus. Both species are differentiated from D. ecuadoriensis by the wider head. The head is 1.1 times longer than wide (PW : EW $=1.24$ in D. brooksi resp. 1.12 in D. mexicanus), whereas it is 1.4 times longer than wide in D. ecuadoriensis (PW : EW = 1.07).

Description: Length: $3.5 \mathrm{~mm}$. Colouration: dark brown; pronotum slightly lighter brown; legs and antennae light brown to yellowish brown; first three antennomeres lighter brown than following antennomeres.

Head: $0.49 \mathrm{~mm}$ long, $0.43 \mathrm{~mm}$ wide; moderately long eyes not prominent; $\mathrm{EL}: \mathrm{HL}=0.20$; temples more than 3 times longer than eyes; distinctly divergent posteriad; PW : EW $=1.24$; setiferous punctation moderately deep and dense; adjacent to impunctate midline with posteriorly convergent line of punctures; between inner line and eyes with supraocular line of 7 punctures; more setiferous punctures on postocular area; netlike microsculpture moderately deep; on vertex elongate meshes transversely striate.

Antennae as long as head and half of pronotum combined; first antennomere longer and slightly thicker than second antennomere; second and third antennomere conical; twice as long as apical width of antennomeres; following antennomeres approximately rectangular; fourth quadrate; tenth nearly 1.5 times wider than long; all antennomeres pubescent; basal antennomeres with setae.

Pronotum: $0.62 \mathrm{~mm}$ long, $0.52 \mathrm{~mm}$ wide; sides nearly parallel; anterior third semi-circular; posterior angles widely rounded; lateral margin fine; in dorsal aspect, visible in posterior third; setiferous punctation sparse; along impunctate midline with three pairs of punctures; interstice between anterior pair of punctures 2.5 times as wide as between posterior pairs of punctures; laterad few more setiferous punctures; along lateral margin with several setiferous punctures; between setiferous punctation with sparse micro-punctation; without microsculpture; surface polished.

Elytra $0.52 \mathrm{~mm}$ long, $0.62 \mathrm{~mm}$ wide; sides slightly divergent to posterior angles; shoulders obtuse; posterior angles rectangular; posterior margin emarginate; setiferous punctation moderately deep and dense; in irregular rows; inner row adjacent to suture line; laterad on disc two more lines with four to five punctures; ground sculpture slightly coriaceous; surface slightly shiny. 
Abdomen densely pubescent.

Aedeagus elongate; seminal vesical of endophallus slender; 0.6 times as long as central lobe; basal inner duct looped; ending in several sclerotised appendices; at apex with sclerotised hooks; paramere slender; sinuate with slightly widened apex; at apex with three long setae; at basal shaft with few sensillae.

Spermatheca approximately circular; $0.35 \mathrm{~mm}$ in diameter; bursa copulatrix in lateral position to irregularly coiled duct.

Etymology: The species name refers to the country, where it was found.

\section{Diochus panamaensis spec. nov.

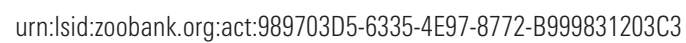 Figs $26 \mathrm{~A}-\mathrm{C}, 39 \mathrm{~K}, 44 \mathrm{~B}$}

Type material: male, Holotype: Panama: Chiriqui Prov., Cerro Colorado, trail to peak, $1475 \mathrm{~m}$ elev., litter at burn tree fern, 28.1.1981, leg. W. Suter (FMNH).

Paratypes: 2 females with same data as holotype (FMNH); same location, but litter shelf-pocket along reopened trail, female, 23.1.1981, leg. W. Suter (FMNH); same location, but cloud forest, Qda. 3w, 1460 m elev., moss on rocks with sphagnum, 1 male, 1? (abdomen lost), 18.1.1981, leg. W. Suter (FMNH); same location, but $1490 \mathrm{~m}$ elev., conc. of woody slash, small clearing, 4 males, 8 females, 11.1.1981, leg. W. Suter (12 FMNH, 2 UIC); Bocas del Toro Prov., Cerro Colorado (W), Qda. 1w, $1450 \mathrm{~m}$ elev., debris on forested slope, 1 male, 3 females, 8.1.1981, leg. W. Suter (FMNH); same location, but litter at stump, 1475 m elev., 2 females, 28.1.1981, leg. W. Suter (FMNH);

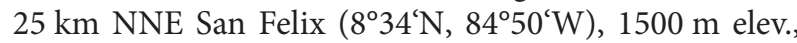
Berlese, conc. of loose root mat nr. ridge top Qda, Alicia cloud forest, 1 male, 3 females, 6.6.1980, leg. J. Wagner (FMNH); same location, but soil u. litter and roots, Berlese, $1500 \mathrm{~m}$ elev., female, 17.6.1980, leg. J. Wagner (FMNH); same location, but Berlese, forest floor conc., Quebrada Alicia cloud forest, 2 males, 1 female, 9.6.1980, leg. J. Wagner (FMNH); same location, but Berlese, floor litter \& mat u. epiphyte log Qda. Alicia cloud forest, male, 8.6.1980, leg. J. Wagner (FMNH); same location, but Berlese, sawdust nr tree hole, Quebrada Alicia cloud forest, female, 10.6.1980, leg. J. Wagner (FMNH); same location, but Berlese, soil beneath litter, Quebrada Alicia cloud forest, 1 male, 1 female, 11.6.1980, leg. J. Wagner (FMNH); same location, fl. litter on slopes, $1500 \mathrm{~m}$ elev., 2 males, 3 females, 4.4.1980, leg. J. Wagner (FMNH); Panama Prov., Cerro Campana, $3200 \mathrm{ft}$. elev., Berlese, forest leaf litter, female, 14., 23.2.1976, leg. A. Newton (FMNH).

Diagnosis: The species is certainly closely related to D. mexicanus due to the reduced eyes and elytra. Within the species group it can be easily identified by the extremely short elytra that are 1.4 times wider than long and 0.7 times as long as pronotum. In the similar D. mexicanus, the elytra are only 1.2 times wider than long and 0.8 times as long as pronotum. Similarly short elytra are also found in D.curtipennis from southern South America. However, this species is placed in the D. schaumii-group due to the structure of the aedeagus.

Description: Length: $3.4 \mathrm{~mm}$. Colouration: brown; elytra slightly darker brown than remaining body; legs light brown; antennae with antennomeres 2 to 7 brown; first antennomere light brown; antennomeres 8 to 11 continuously clearer from antennomere 8 light brown to antennomere 11 yellow.

Head: $0.45 \mathrm{~mm}$ long, $0.37 \mathrm{~mm}$ wide; eyes small; temples three times longer than eyes; $\mathrm{EL}: \mathrm{HL}=0.19$; temples distinctly divergent posteriad; $\mathrm{PW}: \mathrm{EW}=1.23$; posterior margin rounded, but centrally straight; postrior angles obtusely rounded; setiferous punctures deep; along impunctate midline with row of 4 to 5 punctures; laterad with dense punctation; microculpture dense and deep; transversely reticulate; surface matt.

Antennae slightly longer than head; first antennomere thicker and slightly longer than second; second antennomere conical; slightly longer than its apical width; third antennomere as long and wide as second; forth antennomere quadrate, following antennomeres wider than long; seventh and eighth antennomere 1.5 times as wide as long; all antennomeres with short apical setae; setae on basal antennomeres longer; all antennomeres pubescent.

Pronotum: $0.60 \mathrm{~mm}$ long, $0.49 \mathrm{~mm}$ wide; sides nearly parallel; anterior half widely rounded; without angles; obtuse posterior angles shortly rounded; lateral margin fine; in dorsal aspect, only visible in posterior half; along impunctate midline with row of three pairs of punctures; interstice between anterior pair of punctures more than twice as wide than between posterior pairs of punctures; laterad second row with four punctures; several setiferous punctures along lateral margin; without microsculpture; surface polished.

Elytra: $0.41 \mathrm{~mm}$ long, $0.57 \mathrm{~mm}$ wide; sides divergent from shoulders to posterior margin; posterior margin deeply emarginate; shoulder obtuse; setiferous punctures in irregular rows; first row adjacent to suture constisting of 3 to 4 punctures; laterad on disc two more rows; along lateral margin with several setiferous punctures; with weak ground sculpture; surface slightly shiny.

Abdomen densely pubescent.

Aedeagus moderately thick; seminal vesicel of endophallus 0.6 times as long as total length of central lobe; basal inner duct shortly looped; ending in stronger sclerotised structure with forceps; pairs of hook-like sclerotised structures near apex; parameres shorter than central lobe; basal part straight; with short triangular process at middle; apical part elongate; curved; with three setae at upper side; several sensillae at middel part of paramere.

Spermatheca: 0,36 mm long, $0.19 \mathrm{~mm}$ wide; bursa copulatrix outside circularly coiled duct. 
Etymology: The species name derived from the country's name, where it was collected.

\section{Diochus peruvianus spec. nov.

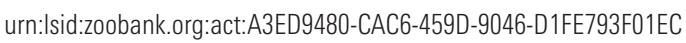 Figs $23 \mathrm{~A}-\mathrm{C}, 39 \mathrm{I}, 43 \mathrm{H}$}

Type material: male, Holotype: Peru: Madre de Dios, Amazonas Lodge, $\mathrm{N}$ Atalaya $\left(71^{\circ} 22.6^{\prime} \mathrm{W}, 12^{\circ} 52.2^{\prime} \mathrm{S}\right)$, $480 \mathrm{~m}$ elevation, collected by flight intercept trap, 10.-13.11.2007, leg. Brzoska \#PER1B07 002 (KNHM).

Paratypes: Brazil: Santa Catarina, Nova Teutonia, 1 male, 5 females, 12.1953, leg. F. Plaumann (FMNH); Santa Catarina, without more details, 1 male, 6 females, leg. P.E. Klimsch (NMW); Argentina: Salta Prov., 1-6 mi. W of Aguas Blancas, road to Parq. Nat. Baritu $\left(22^{\circ} 44^{\prime} \mathrm{S}\right.$, $\left.64^{\circ} 22^{\prime} \mathrm{W}\right), 490 \mathrm{~m}$ elevation, leaf litter near stream, 2 males, 3 females, 14.11.1995, leg. L. Herman (AMNH); Salta Prov. $2 \mathrm{~km}$ NW Tobantirenda nr. Dique $\left(22^{\circ} 07^{\prime} \mathrm{S}\right.$, $\left.63^{\circ} 43^{\prime} \mathrm{W}\right), 575 \mathrm{~m}$ elevation, leaf litter nr. stream, 4 males, 4 females, 15.11.1995, leg. L. Herman (6 AMNH, 2 UIC); Jujuy Prov. $8 \mathrm{~km}$ NW Calilegua $\left(23^{\circ} 45^{\prime} \mathrm{S}, 64^{\circ} 51^{\prime} \mathrm{W}\right)$, $635 \mathrm{~m}$ elevation, litter near stream, 12 males, 6 females, 12.11.1995, leg. L. Herman (16 AMNH, 2 UIC).

Diagnosis: The species resembles a large D. brooksi in colouration of the body and antennae, but is much longer than that species. The paramere is unique with the recurved apex. Without dissecting the aedeagus a differentiation from similarly large and coloured species of other species groups is difficult, e.g. D. hermani, D. vicinus.

Description: Length: $4.9 \mathrm{~mm}$ Colouration: black; legs brown; antennomeres one to three light yellowish brown; following antennomeres dark brown; last antennomere brown with light apex.

Head: $0.63 \mathrm{~mm}$ long, $0.56 \mathrm{~mm}$ wide; large eyes slightly prominent; temples 1.3 times longer than eyes; $\mathrm{EL}: \mathrm{HL}=0.29$; temples nearly parallel; $\mathrm{PW}: \mathrm{EW}=1.06$; posterior angles shortly rounded; setiferous punctation denser on clypeus than on vertex; pair of rows with four supraocular punctures posteriorly convergent; in anterior part, between rows with irregular dense punctation; ending posteriorly at third pair of punctures; temples with dense setiferous punctation; without microsculpture; surface shiny.

Antennae as long as head and half of pronotum combined; first antennomere more than twice as long as wide; second antennomere shorter; twice as long as wide; conical third antennomere 1.4 times as long as second; 2.3 times as long as wide; length of following antennomeres decreasing; fourth antennomere slightly longer than wide; tenth slightly wider than long; all antennomeres pubescent and with apical setae; basal antennomeres with thicker setae.

Pronotum: $0.90 \mathrm{~mm}$ long, $0.72 \mathrm{~mm}$ wide; sides approximately parallel; anterior angles widely rounded; anterior margin nearly semi-circular; posterior angles shortly rounded; lateral margin fine; in dorsal aspect, visible in posterior half; wide midline impunctate; along midline, three pairs of setiferous punctures; interstice between first pair of punctures twice as wide as between posterior two pairs; laterad several irregular setiferous punctures; along lateral margin with several setiferous punctures; without microsculpture; surface polished.

Elytra: $0.83 \mathrm{~mm}$ long, $0.89 \mathrm{~mm}$ wide; posteriad, sides slightly divergent; at posterior angles 1.2 times as wide as at shoulder; shoulders shortly rounded; setiferous punctation in irregular rows of five to seven punctures; interstice between sutural row and disc rows wider than between disc rows; with sparse non-setiferous punctures; several setiferous punctures along lateral margin; without ground sculpture; surface shiny.

Abdomen densely pubescent.

Aedeagus elongate; seminal vesical of endophallus thick; less than half as long as central lobe; basal inner duct ending in weakly sclerotised forceps; paramere shorter than central lobe; slender and curved in apical third; clapsing central lobe; ending in acute apex; at outer edge of apical third with three long setae; basal shaft with few sensillae.

Spermatheca $0.46 \mathrm{~mm}$ long, $0.36 \mathrm{~mm}$ wide; weakly oval; bursa copulatrix in lateral position to coiled duct; coiled duct with strongly irregular coils.

Etymology: The species name derived from the country, where it was collected.

\section{Diochus pumilio BERNHAUER, 1929}

Figs 25A-C, 39H, 44A

Diochus pumilio BernhaUer, 1929: 193

Type material examined: Syntypes: Mexico: Veracruz, Fauler Stamm Kokospalme (rotting cocos palme), 2 males, 31.10.1926, leg. Dampf, \#197 (FNHM), same location, but Luftkescherung (air catch), female, 3.12.1926, leg. Dampf, same location, but Morscher Stamm (decaying trunk), 11.-12.1926, leg. Dampf (FMNH). The male without number was selected as Lectotype.

Further material examined: Mexico: Chiapas, El Chorreadoro, $8 \mathrm{~km}$ SE Chiapa de Corzo, $650 \mathrm{~m}$ elevation, sifted deep leaf litter in rock crevasses, 1 male, 2 females, 11.6.1991, leg. J. Ashe \#90 (2 KNHM, 1 UIC); Union Juarez, NW slope Volcan Tacana, leaf litter weedy areas under coffee, 1000 m elev., female, 3.1.1977, leg. H. Frania (AMNH); Veracruz, air catch, 1 male, 3 females, 31.12.1926, 11.-12.1926, leg. Dampf (FMNH); Chiapas, Chorreodero, NE Tuxtla Gutz., $730 \mathrm{~m}$ elev., tropical deciduous, sifting, litter along stream, female, 5.5.1977, leg. J.S. Ashe (FMNH); S.L.P., $15 \mathrm{mi} \mathrm{N}$ Tamazunchale, $500 \mathrm{ft}$. elev., deposit Atta mexicana, female, 26.6.1973, leg. A. Newton (FMNH) 
Diagnosis: Within the D. maculicollis-group, Diochus pumilio is characterised by its small size. It is similarly small as the species of the $\mathrm{D}$. nanus-group and can be hardly differentiated from those species. However, D. pumilio is clearly identified by its unique aedeagus with the short and nearly globular seminal vesical and the non-looped basal inner duct.

Description: Length: $2.5 \mathrm{~mm}$. Colouration: yellow; pronotum slightly lighter yellow than head, elytra, and abdomen; basal three antennomeres lighter yellow than following antennomeres.

Head: $0.39 \mathrm{~mm}$ long, $0.32 \mathrm{~mm}$ wide; eyes slightly prominent; small; temples 2.3 times as long as eyes; EL : $\mathrm{HL}=0.22$; temples slightly divergent posteriad, $\mathrm{PW}: \mathrm{EW}=1.11$; posterior angles shortly rounded, posterior margin straight; setiferous punctation moderately deep and dense; narrow midline impunctate; on vertex two pairs of punctures adjacent to midline; on clypeus and on supraocular area between pairs of punctures with irregular punctation; postocular area more densely punctate; netlike microsculpture deeper and narrower on clypeus than on vertex; surface moderately shiny.

Antennae as long as head and half of pronotum combined; basal three antennomeres conical; decreasing in length from first to third antennomere; approximately twice as long as at their apical width; following antennomeres distinctly shorter than preceding antennomeres; fourth quadrate; tenth 1.5 times as wide as long; all antennomeres pubescent; basal antennomeres with apical setae.

Pronotum: $0.47 \mathrm{~mm}$ long, $0.40 \mathrm{~mm}$ wide; widest close to middle; anterior third semi-circular; in anterior half; sides approximately parallel; posterior angles shortly rounded; posterior margin curved in slightly convex curve; lateral margin fine; in dorsal aspect, visible in posterior third; setiferous punctation deep and sparse; along impunctate midline with three pairs of punctures; interstice between anterior pair, 1.5 times as wide as between posterior pairs; laterad four partly deeper punctures; along lateral margin several punctures; without microsculpture, but with weak micro-punctation; surface polished.

Elytra: $0.46 \mathrm{~mm}$ long, $0.46 \mathrm{~mm}$ wide; sides slightly divergent posteriad, but nearly parallel; shoulders obtuse; posterior angles rectangular; posterior margin deeply emarginate in laterally sinuate curve; setiferous punctation in irregular rows of six to seven punctures; inner row adjacent to suture line; interstice between inner row and second row slightly wider than between two lateral rows; along lateral margin several setiferous punctures; ground sculpture weakly coriaceous; surface slightly shiny.

Abdomen densely pubescent.

Aedeagus moderately thick; seminal vesical of endophallus ovel, but nearly globular; 0.4 times as long as total length of central lobe; basal inner duct thick; slightly curved anteriad; ending in weakly sclerotised forceps; paramere slender; obtusely curved in anterior third; ending in obtusely rounded apex without widening; curved apical part with two long setae; shaft with basal group of sensillae.

Spermatheca irregularly shaped; bursa copulatrix in lateral position to coiled duct; coils of duct irregular and with only few coils.

\section{Diochus schaumii-group}

\section{Diochus angustiformis spec. nov.

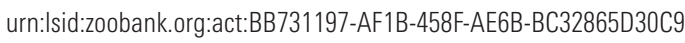 Figs 28A-C, 39L, 44C}

Type material: male, Holotype: Costa Rica: S Rincon de la Vieja, Rd. Hacienda Guachipilin > Santa Maria $\left(10^{\circ} 42.43^{\prime}-45.10^{\prime} \mathrm{N}, \quad 85^{\circ} 20.15^{\prime}-22.45^{\prime} \mathrm{W}\right), \quad 520-700 \mathrm{~m}$ elevation, car net, farmland \& dry forest, 4.12.2012, leg. Schülke \& Grünberg (MSC).

Paratypes: Mexico: Chiapas, Pozas, de Berriozabal, ca. $5 \mathrm{~km}$ W Tuxtla, $750 \mathrm{~m}$ elevation, leaf litter at base of escarpment along stream, 2 males, 4 females, 3.6.1991, leg. J. Ashe, \#53 (KNHM); Chiapas, Cinco Cerros, 5 km $\mathrm{S}$ Rizo de Oro, sifted leaf litter in dry stream bed, $810 \mathrm{~m}$ elevation, female, 8.6.1991, leg. J. Ashe \#78 (KNHM); Chiapas, El Chorreadero, $8 \mathrm{~km}$ SE Chiapa de Corzo, sifted leaf litter, $650 \mathrm{~m}$ elevation, female, 3.6.1991, leg. J. Ashe \#56 (KNHM); Just E Acala, SE of Tuxtla Gutierrez $\left(16^{\circ} 38^{\prime} \mathrm{N}, 92^{\circ} 48^{\prime} \mathrm{W}\right)$, rocky edge of large stream in shade, $3200 \mathrm{ft}$., 1 male, 1 female, 2.1.1973, lg. H. Frania (AMNH); Chiapas, $12 \mathrm{mi}$ NW Ocozocautla, $3200 \mathrm{ft}$. elev., Berlese, litter oak-tropical evergreen forest, 3 males, 2 female, 4.9.1973, leg. A. Newton (FMNH); Chiapas, El Chorreodero, NE Tuxtla Gutz, 730 m elev., sifting, tropical deciduous litter along stream, female, 5.5.1977, leg. J.S. Ashe (FMNH); Jalisco, Puerto Los Mazos, 10 mi SW Autlán, 4400 ft elev., Berlese, litter oaktropical decid. forest, male, 25.9.1973, leg. A. Newton (FMNH); S.L. Potosi, $3 \mathrm{mi} \mathrm{W}$ El Naranjo, sifting, leaf litter, female, 1.-18.6.1971, leg. A. Newton (FMNH); Oaxaca, 7.3.mi N Chacalpa, Hwy $75\left(96^{\circ} 28^{\prime} \mathrm{W}, 15^{\circ} 49^{\prime} \mathrm{N}\right)$, $410 \mathrm{~m}$ elev., tropical deciduos forest, sfting, leaf litter, 29.4.1977, leg. J.S. Ashe (FMNH); Belize: Orange Walk District, Rio Bravo Conserv. Area, pond at end Orchard trail $\left(17^{\circ} 50.48^{\prime} \mathrm{N}, 89^{\circ} 02.43^{\prime} \mathrm{W}\right)$, water edge litter, 1 male, 2 females, 28.4.1996, leg. C. Carlton (2 KNHM, 1 UIC); same region, but $\mathrm{Rd}$ to Archaeological site $\left(17^{\circ} 50.27^{\prime} \mathrm{N}\right.$, $\left.89^{\circ} 01.8^{\prime} \mathrm{W}\right), 3$ females, 25.4.1996, leg. C. Carlton, \#036 (2 KNHM, 1 UIC); same location, but $\left(17^{\circ} 50.33^{\prime} \mathrm{N}\right.$, $\left.89^{\circ} 01,28^{\prime} \mathrm{W}\right)$, collected by flight intercept trap, 2 females, 18.-25.4.1996, leg. C. Carlton \& V. Mosley, \#026 (KNHM); same location, but Archaeological camp. $\left(17^{\circ} 50.28^{\prime} \mathrm{N}, 89^{\circ} 01.09^{\prime} \mathrm{W}\right)$, collected by berlese, female, 4.4.1996, leg. C. Carlton, \#091 (KNHM); same region, Rio Bravo Conserv. Area, La Milpa $\left(19^{\circ} 50.23^{\prime} \mathrm{N}\right.$, $\left.89^{\circ} 01.06^{\prime} \mathrm{W}\right)$, UV light, female, 1.5.1996, leg. C. Carlton, V. Moseley \#077 (KNHM); Guatemala: Zacapa, $7.6 \mathrm{~km}$ W Teculatán, $330 \mathrm{~m}$ elevation, along stream in leaf packs, male, 26.6.1993, leg. J. Ashe \& R. Brooks, \#03-108 
(KNHM); Nicaragua: Rio San Juan Dept., 60 km SE San Carlos, Refugio Bartola $\left(10^{\circ} 58.40^{\prime} \mathrm{N}, 84^{\circ} 20.30^{\prime} \mathrm{W}\right)$, $100 \mathrm{~m}$ elevation, collected by mercury vapor/UV light trap, 2 males, 30.5.2002, leg. R. Brooks \& Z. Falin, \#NIC1BFC02 129 (1 KNHM, 1 UIC); Costa Rica: from same location, same date, and same collectors as holotype, male (UIC); Puntarenas Province, Osa peninsula, Rd Rincon de Osa > Chacarita $\left(8^{\circ} 42^{\prime}-48^{\prime} \mathrm{N}, 83^{\circ} 15^{\prime}-\right.$ $\left.29^{\prime} \mathrm{W}\right)$, car net, devastated forest \& plantations, female, 10.12.2013, leg. Schülke \& Grünberg (MSC); Guanacaste, Palo Verde Biological Station, Sendero Natural la Venada $\left(10^{\circ} 20.56^{\prime} \mathrm{N}, 85^{\circ} 19.53^{\prime} \mathrm{W}\right)$, fogging fungus covered log, 2 males, 16.7.2000, leg. J. Ashe, R. Brooks \& Z. Falin, \#CR1ABF00 148, (KNHM); Rio Virilla, 1 male, 1 female, 2.1935, leg. A. Bierig (FMNH); San José, 1935, leg. A. Bierig (FMNH); Cuba: Varadero $\left(81^{\circ} 11^{\prime} \mathrm{W}\right.$, $\left.23^{\circ} 10^{\prime} \mathrm{N}\right), 2$ males, 4 females, 16.6.2003, leg. Brachat (4 VAC, 2 UIC); Habana Prov. Guanabo, 17 males, 15 females, 14.2.1931, leg. A. Bierig (30 FMNH, 2 UIC); Sierra Bonilla, Cueva del Indio, male, 5.1.1929, leg. A. Bierig (FMNH); Almendares, female, 12.1.1927, leg. A. Bierig (FMNH); Rio Ariguanabo, 1 male, 1 female, 16.3.1929, 22.3.1930, leg. A. Bierig (FMNH); Cueva del Indio, Tapaste Dis., 2 males, 2.1928, leg. A. Bierig (FMNH); La Lisa, female, 20.9.1931, leg. A. Bierig (FMNH); Cojimar, male, 27.10.1928, leg. A. Bierig (FMNH); Sierra del Rosario, Cayajabos, female, 25.3.1933, leg. A. Bierig (FMNH); Loma del Candela, Güines, 5 females, 12.2.1938, leg. A. Bierig (FMNH); Jamaica: Cane River Falls, St. Andrew, $500 \mathrm{ft}$. elev., leaves in spray, 1 male, 1 female, 31.7.1956, leg. P.F. Bellinger (FMNH); Dominican Republic: Prov. Duarte, 7.5 mi. NE San Francisco de Macornis, Loma de Quita Espuela, litter nr. stream, 1 male, 800 ft. elev., 24.7.1991, leg. L. Herman \#2599 (AMNH).

Diagnosis: The species extremely resembles $D$. schaumii in size and the light brown colouration. It can be differentiated from $D$. schaumii by the slightly more prominent eyes and the posteriorly more divergent head. D. schaumii has a more parallel head. The PW : EW ratio is 1.06, whereas it is 1.26 in D. angustiformis. The species is mainly characterised by the specific shape of the paramere, which is extremely asymmetric at apex. In contrast to these two species, the similarly sized D. brunneus is darker in colour with the anterior half of the pronotum light brown.

Description: Length $3.8 \mathrm{~mm}$. Colouration: unicoloured brown, pronotum slightly lighter brown; abdominal segments III-VI slightly darker brown; legs and antennae lighter brown, except antennomeres IV to X darker.

Head: $0.49 \mathrm{~mm}$ long, $0.43 \mathrm{~mm}$ wide; eyes slightly prominent; $\mathrm{EL}: \mathrm{HL}=0.28$; temples 1.8 times as long as eyes; temples divergent to posterior angles; PW : $\mathrm{EW}=1.26$; posterior angles widely rounded; posterior margin convexly curved; setiferous punctation deep and moderately dense; along impunctate midline with parallel row of setiferous punctures; on clypeus few punctures between rows, supraocular row of four punctures laterad to central row; several more supraocular punctures; postocular area more densely punctate; microsculpture weak; transversely and diagonally striate; surface slightly shiny.

Antennae as long as head and half of pronotum combined; first elongate antennomere thicker than following antennomeres; more than twice as long as its apical width; second conical antennomere twice as long as its apical width; third antennomere narrower than second and also twice as long as its apical width; length of following antennomeres decreasing; fourth slightly longer than wide; tenth antennomere slightly wider than long; all antennomeres pubescent and with few apical setae.

Pronotum: $0.68 \mathrm{~mm}$ long, $0.56 \mathrm{~mm}$ wide; widest in posterior half; slightly convergent to anterior angles; anterior angles widely rounded; anterior margin nearly semicircular; posterior angles widely rounded; lateral margin fine; in dorsal aspect, visible in posterior half; posterior margin convex; setiferous punctation moderately deep and sparse; along impunctate midline with three pairs of punctures; interstice between anterior pair nearly three times as wide as between posterior two pairs of punctures; three to four setiferous punctures laterad; along lateral margin numerous punctures with long setae; without microsculpture; with dense micro-punctation; surface shiny.

Elytra: $0.67 \mathrm{~mm}$ long, $0.72 \mathrm{~mm}$ wide; sides divergent to posterior angles; shoulders obtusely angulate; posterior angles nearly rectangular; posterior margin triangularly emarginate; setiferous punctation in irregular rows of seven to eight punctures; first row adjacent to suture line; two additional rows on disc; interstice between first row and second row twice as wide as between second row and third row; along lateral margin several setiferous punctures; ground-sculpture weakly coriaceous; slightly less shiny than pronotum.

Abdomen densely pubescent.

Aedeagus moderately slender; seminal vesical of endophallus 0.6 times as long as total length of central lobe; basal inner duct looped; ending in sclerotised forceps; two hooks at apex; paramere moderately thick; shaft in central part longitudinally folded; apical part largely widened; forming large triangular process; at base of triangle with two long apical setae; near acute apex with one shorter seta.

Spermatheca approximately circular; $0.33 \mathrm{~mm}$ in diameter; bursa copulatrix in lateral position to coiled duct; coiled duct with numerous irregular coils.

Etymology: The species name is a combination of the epithet angusti derived from the Latin word angustus meaning small and formis meaning shaped and refers to the narrow shape of the head compared to D. brunneus. 
Diochus argentinae spec. nov.

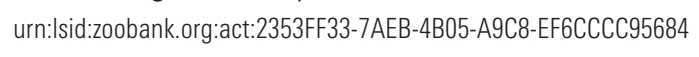

Figs 29A-C, 40A, 44F

Type material: male, Holotype: Argentina: Buenos Aires, Tigre, 6.1938, leg. M.J. Viana, (labelled by Bernhauer as D. nanus) (FMNH).

Paratypes: Argentina: Buenos Aires, Isla Martin Garcia, male, 1939, leg. M.J. Viana (FMNH); Tucuman, Cerro de San Javier, humus, $1000 \mathrm{~m}$ elev., male, 8.5.1953, leg. P. Wygodzinsky (FMNH); Rosas, - F.C.Sud, leg. J.D. Daguerre (coll. Bruch) 2 females, (1 FMNH, 1 UIC); Brazil: Nova Teutonia $\left(27^{\circ} 11^{\prime} \mathrm{S}, 52^{\circ} 23^{\prime} \mathrm{W}\right), 300-500 \mathrm{~m}$ elev., 2 males, 3 females, 3.1954, leg. F. Plaumann (4 FMNH, 1 UIC).

Diagnosis: Regarding the structure of the aedeagus, $D$. argentinae is related to D. schaumii, and D. brunneus. The shape of the paramere is intermediate between both species. The apical widening is longer than in D. schaumii, but shorter than in D. brunneus. The three species and D. angustiformis can be also differenciated by the shape of the head. The sides of head of $D$. argentinae and D. schaumii are approximately parallel (PW : EW = 1.06), whereas they are slightly divergent in D. brunneus and D. angustiformis (PW : EW 1.26). The head of $D$. shaumii is longer (length/width ratio 1.35) than that of $D$. argentinus (length/width ratio 1.25). Furthermore, it can be differentiated from D. brunneus by the unicoloured light brown pronotum. The pronotum of $D$. brunneus is light brown in its anterior half, but dark brown in its posterior half.

Description: Length: $3.9 \mathrm{~mm}$. Colouration: dark brown; Pronotum slightly lighter brown; posterior margin of elytra light brown; legs light brown; basal two antennomeres lighter brown than following antennomeres.

Head: $0.49 \mathrm{~mm}$ long, $0.39 \mathrm{~mm}$ wide; eyes large; prominent; $\mathrm{EL}: \mathrm{HL}=0.30$, temples approximately parallel; $\mathrm{PW}: \mathrm{EW}=1.06$; posterior angles widely rounded; setiferous punctation deep; on each side of impunctate midline with row of three punctures; between inner row and eyes with second row of five punctures; postocular area irregularly punctate; without microsculpture; surface shiny.

Antennae slightly longer than head and pronotum combined; first antennomere slightly thicker than following antennomeres; second and third antennomere conical and nearly twice as long as its apical width; fourth antennomere slightly longer than wide; following antennomeres wider than long; penultimate antennomeres approximately one third wider than long; all antennomeres pubescent and with few apical setae.

Pronotum: $0.53 \mathrm{~mm}$ long, $0.51 \mathrm{~mm}$ wide; sides approximately parallel; anterior third widely rounded; nearly semi-circular; posterior angles shortly rounded; lateral margin fine; in dorsal aspect visible in posterior half; setiferous punctation deep, but sparse; row of three punc- tures on each side of impunctate midline; between central row and lateral margin several irregular punctures; between coarser setiferous punctures with sparse micropunctation; without microsculpture; surface polished.

Elytra: $0.71 \mathrm{~mm}$ long, $0.71 \mathrm{~mm}$ wide; sides slightly divergent to posterior angles; shoulders widely rounded; posterior angles nearly rectangular; posterior margin slightly emarginate; setiferous punctation in irregular rows; rows with 7 to 8 punctures; surface wth weak coriaceous ground sculpture; less shiny than head or pronotum.

Abdomen densely pubescent.

Aedeagus moderately thick; seminal vescical of endophallus two third as long as total length of central lobe; basal inner duct ending in irregularly sclerotised appendices; apical hooks thick; parameres moderately thick; not longer than central lobe; apical widening asymmetric; forming a broad triangle; with two setae at apical margin; three sensillae at middle of shaft.

Spermatheca $0.25 \mathrm{~mm}$ long, 0.18 wide; bursa copulatrix outside of coiled duct; coiled duct approximately circular.

Etymology: The species name derived from Argentina, one of the countries where it was found.

\section{Diochus brunneus spec. nov.

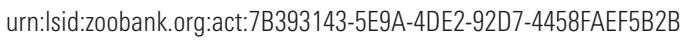 Figs $30 \mathrm{~A}-\mathrm{C}, 40 \mathrm{~B}, 44 \mathrm{D}$}

Type material: male, Holotype: Costa Rica: Cartago Province, W Cachi, S-side, Cachi lake $\left(9^{\circ} 48.47^{\prime}-49.20^{\prime} \mathrm{N}\right.$, $\left.83^{\circ} 48.42^{\prime}-50.33^{\prime} \mathrm{W}\right), 1010-1040 \mathrm{~m}$ elevation, road along lake shore, secondary forest, coffee plant., gardens, car net, 6.12.2013, leg. M. Schülke \& B. Grünberg (MSC).

Paratypes: 2 females same location, date and collectors as holotype, 2 males from same location and collectors as holotype, but 7.12.2013 (2 MSC, 2 UIC); Panama: Colon, Parque Nac. Soberania, Pipeline Rd. km $2.0\left(9^{\circ} 07^{\prime} \mathrm{N}\right.$, $\left.79^{\circ} 45^{\prime} \mathrm{W}\right), 40 \mathrm{~m}$ elevation, collected by flight intercept rap, male, 29.-31.5.1995, leg. J. Ashe, \#084 (KNHM).

Diagnosis: Within the species group, D. brunneus is characterised by its dark brown colouration with lighter brown anterior half of pronotum. However, the main character to identify the species is the shape of the paramere with the long asymmetric apical process. A bicoloured pronotum is also found in D. hibbsi of the Diochus inornatus-group. D. hibbsi is considerably larger than D. brunneus, and the pronotum has a light brown posterior half, whereas the pronotum of $D$. brunneus has a light brown anterior half.

Description: Length: $4.0 \mathrm{~mm}$. Colouration: dark brown; anterior half of pronotum, posterior margin of elytra, posterior half of abdominal segment VIII, and legs light brown; basal antennomeres and apex of eleventh antennomere light brown. 
Head: $0.57 \mathrm{~mm}$ long, $0.48 \mathrm{~mm}$ wide; eyes slightly prominent; large; temples twice as long as eyes; EL : $H L=0.29$; temples slightly divergent posteriad; PW : EW 1.26; posterior angles widely rounded to slightly curved posterior margin; setiferous punctures deep; along impunctate midline with irregular row of four setiferous punctures; convergent posteriad; on clypeus few punctures between the medial rows; second supraocular row posteriad convergent; ending at middle of vertex; postocular area with denser setiferous punctation; very weak diagonally striate microsculpture; surface slightly shiny.

Antennae as long as head and half of pronotum combined; slightly thicker and longer than following antennomeres; second conical antennomere 0.7 times as long as first; more than twice as long as its apical width; third antennomere equal in length and width as second; length of following antennomeres decreasing; fourth antennomere slightly longer than wide; tenth slightly wider than long; all antennomeres pubescent and with few apical setae.

Pronotum: $0.75 \mathrm{~mm}$ long, $0.64 \mathrm{~mm}$ wide; widest in posterior half; sides slightly convergent to anterior margin; anterior angles widely rounded; anterior margin nearly semi-circular; posterior angles shortly rounded; lateral margin fine; in dorsal aspect, visible in posterior half; setiferous punctures sparse and as deep as on head; along impunctate midline, three pairs of punctures convergent posteriad; interstice between first pair three times as wide as between posterior pair; interstice of intermediate pair intermediately wide; between this row and lateral margin three to four more punctures in irregular row; more setiferous punctures along lateral margin; without microsculpture; surface polished.

Elytra: $0.75 \mathrm{~mm}$ long, $0.77 \mathrm{~mm}$ wide; sides slightly divergent posteriad; shoulders obtusely angulate; posterior angles nearly rectangular; posterior margin with slightly triangular emargination; setiferous punctation in irregular rows; inner row of five to six punctures adjacent to suture line; two more rows on disc; along lateral margin several setiferous punctures; weak coriaceous ground sculpture; surface less shiny than pronotum.

Abdomen densely pubescent.

Aedeagus elongate; seminal vesical of endophallus slender; 0.56 times as long as total length of central lobe; basal inner duct looped ending in sclerotised forceps; paramere broad; in apical half folded in one transparent lobe and one more sclerotised lobe; obtusely angulate in apical third; transparent apical lobe triangularly elongate; at angle with two long setae; at apex with one slightly shorter seta.

Spermatheca $0.47 \mathrm{~mm}$ long, $0.29 \mathrm{~mm}$ wide; bursa copulatrix in lateral position to coiled duct; coiled duct divided into approximately circular part and coiled connection to bursa copulatrix; circular part with numerous partly irregular coils; connection to bursa copulatrix with irregular coils.
Etymology: The species name derived from the same Latin word meaning brown and describes the dark brown colouration.

\section{Diochus curtipennis spec. nov.

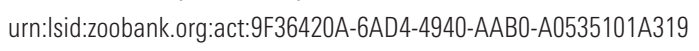 Figs $31 \mathrm{~A}-\mathrm{C}, 40 \mathrm{C}, 44 \mathrm{G}$}

Type material: male, Holotype: Brazil: Santa Catarina, Linha Facão, May 1954, leg. F. Plaumann (KNHM). Paratypes: 1 male with same data as holotype (KNHM); Nova Teutonia, Santa Catarina, female, 12.1953, leg. F. Plaumann (FMNH); Argentina: Jujuy, Termas de Reyes, male, 27.12.1971, leg. L. Herman \#829 (AMNH); San Luis Prov. Irideus, Quebrada del Tala $\left(32^{\circ} 39.01^{\prime} \mathrm{S}\right.$, $\left.64^{\circ} 57.23^{\prime} \mathrm{W}\right)$, litter in moist narrow quebrada, $1100 \mathrm{~m}$ elev., male, 8.12.2000, leg. L. Herman (UIC); Aguas Buenas $\left(32^{\circ} 35.05^{\prime} \mathrm{S}, 64^{\circ} 57.01^{\prime} \mathrm{W}\right)$, litter near stream, $1070 \mathrm{~m}$ elev., male, 9.12.2000, leg. L. Herman (AMNH); Cerro El Mago, cuesta norte $\left(32^{\circ} 43.01^{\prime} \mathrm{S}, 66^{\circ} 09.40^{\prime} \mathrm{W}\right)$, under rocks, $1660 \mathrm{~m}$ elev., female, 5.12.2000, leg. L. Herman (AMNH); Tucuman, Villa Nugués, female, 13.12.1971, leg. L. Herman \#781 (AMNH); 7 km W San Pedro de Colalao, female, 15.12.1971, leg. L. Herman \#786 (AMNH); Tucuman, Parque Aconguija, $800 \mathrm{~m}$ elev. leaf litter, 1 male, 1 female, 30.3.1953, leg. Wygodzinsky (FMNH); Choromora, Quebrada de la Higuera, $800 \mathrm{~m}$ elev., forest floor debris, 3 females, 15.3.1953, leg. Wygodzinsky (FMNH).

Diagnosis: Within the species group, the species is easily to distinguish by the short elytra that are distinctly wider than long. The paramere resembles that of D. brunneus in shape, but the apical plate is broader and with slightly sinuate upper margin. Species with similarly short elytra are found in the D. brooksi-group, i.e. D. mexicanus and D. panamensis from Central America. The eyes are slightly larger in D. curtipennis $(\mathrm{EL}: \mathrm{HL}=0.25)$ compared to those two species (maximum EL : $\mathrm{HL}=0.20$ ) and the head less divergent to posterior angles.

Description: Length: $3.2 \mathrm{~mm}$. Colouration: dark brown; pronotum and clypeus lighter brown; legs and antennae still lighter brown, except antennomeres four to eleven dark brown.

Head: $0.49 \mathrm{~mm}$ long, $0.42 \mathrm{~mm}$ wide; eyes slightly prominent; moderately large; temples 2.5 times as long as eyes; $\mathrm{EL}: \mathrm{HL}=0.25$; temples moderately divergent posteriad; $\mathrm{PW}: \mathrm{EW}=1.19$; posterior angles widely rounded to approximately straight posterior margin; setiferous punctation moderately deep and dense; vertex with impunctate midline; adjacent to impunctate midline with row of five punctures; on supraocular area, laterad to medial row with dense setiferous punctation; postocular area with several punctures; distinct microsculpture deeper on clypeus than on vertex; on clypeus, microscu- 
lpture closely netlike; on vertex with transverse, elongate meshes; surface slightly shiny.

Antennae short; slightly longer than head; first elongate antennomere thicker than following antennomeres; nearly twice as long as apical width; second and third antennomeres conical; slightly shorter than twice as long as its apical width; following antennomeres wider than long; tenth antennomere 1.3 times as wide as long; all antennomeres pubescent and with long apical setae. Pronotum: $0.67 \mathrm{~mm}$ long, $0.52 \mathrm{~mm}$ wide; sides approximately parallel; in anterior half continuously rounded; anterior third semi-circular; posterior angles shortly rounded to slightly convex posterior margin; lateral margin fine; in dorsal aspect, visible in posterior half; setiferous punctures moderately deep and sparse; adjacent to impunctate midline three pairs of setiferous punctures; interstice between anterior pair 2.6 times as wide as interstices between posterior pairs; laterally with curved row of four to five punctures; along lateral margin several setiferous punctures; without microsculpture; surface polished.

Elytra: $0.52 \mathrm{~mm}$ long, $0.60 \mathrm{~mm}$ wide; sides distinctly divergent to posterior angles; shoulders nearly absent; at posterior angles 1.3 times as wide as at shoulders; posterior angles shortly rounded to deeply emarginate posterior margin; setiferous punctation in irregular rows of six punctures; first row adjacent to suture line; laterally with two additional rows of three to four punctures; interstice between suture row and next lateral row wider than between two rows on disc; ground sculpture weakly coriaceous; surface slightly shiny.

Abdomen densely pubescent.

Aedeagus thick; seminal vesical of endophallus long and moderately thick; three fourth as long as total length of central lobe; basal inner duct looped with apical appendices; paramere shorter than central lobe; in apical third widened to oval plate with three long setae at upper margin; upper margin slightly sinuate close to outer angle; slender shaft with four sensillae.

Spermatheca $0.27 \mathrm{~mm}$ long, $0.18 \mathrm{~mm}$ wide; bursa copulatrix in lateral position to coiled duct; coiled duct with several irregular coils.

Etymology: The specific name is a combination of the Latin words curtus for short and pennis for elytra. It refers to the short elytra of the species.

\section{Diochus schaumii KraATZ, 1860 \\ Figs 27A-C, 40D, 44E}

Diochus schaumii KraAtz, 1860: 27

Diochus vilis SHaRp, 1885: 467 new synonymy

Type material examined: Lectotype: USA: male, Louisiana, coll. Kraatz (SDEI).

Paralectotypes: female, America borealis D. schaumii; female, Georgia, Gerh. (SDEI). Syntypes of D. vilis:
Guatemala: 1 male, 1 female, near the city, leg. Champion $(\mathrm{BMNH})$

Further material examined: Mexico: San Luis Potosi, $14.4 \mathrm{~km} \mathrm{~N}$ Tamazunchale, Hwy. $85100 \mathrm{~m}$ elevation, under bark, 2 males, 9.7.1990, leg. J.S. Ashe, K.J. Ahn, R. Leschen \#31 (1 KNHM, 1 UIC); Chiapas, Parque Laguna Belgica, $19.3 \mathrm{~km}$ N Ocozocoautla, $970 \mathrm{~m}$ elevation, sifted deep rat litter in forest, female, 8.6.1991, leg. J. Ashe \#77 (KNHM); Unión Juárez, NE slope of Volcan Tacaná, 1630 m elev., 3 males, 1 female, 15.12.1975, leg. H. Frania \#117-75 (AMNH); same location, leaf litter under coffee, finca in Guat., 2 females, 18.12.1976, leg. H. Frania \& D. Proctor (AMNH); R1m of gorge, $2 \mathrm{mi} \mathrm{S}$ of Sumidero, 3 males, 4 females, 17.8.1966, leg. J. \& W. Ivie (6 AMNH, 1 UIC); Tamaulipas, Cueva de los Cuarteles, 10 km SW Aldama, male, 11.1.1977, leg. J. Reddell \& A. Grubbs (AMNH); Najarit, San Blas, coco by roots of big tree, female, 11.8.1980, leg. L.E. Watrou, \#8 (AMNH); Jalisco, km $59 \mathrm{~N}$ of Barra de Navidad, on Rt 200 UNAM Field Station at Chamela, forest litter, Berlese, 150-300 ft., 5 males, 11 females, 4.-7.4.1985, leg. R.T. Schuh, B.M. Massie (15 AMNH, 1 UIC); Hidalgo, Munic., Huejutla, Tulastitla $\left(21^{\circ} 04.22^{\prime} \mathrm{N}\right.$, $98^{\circ} 32.49^{\prime} \mathrm{W}$ ), leaf litter, $743 \mathrm{~m}$ elev., female, 15.10.2006, leg. L. Herman (AMNH); Veracruz, Cordoba, without further data, leg. Fenyes (FMNH); Jalisco, E slope Nevado de Colima, $8000 \mathrm{ft}$., male, 21.9.1973, leg. A. Newton (FMNH); Puerto Los Mazos, $10 \mathrm{mi}$. SW Autlán, $4400 \mathrm{ft}$. elev., Berlese, oak tropical decid. forest, 1 male, 3 females, 25.9.1973, leg. A. Newton (FMNH); Guatemala: Baja Vera Paz, $16.5 \mathrm{~km} \mathrm{~N}$, Salamá $\left(15^{\circ} 14^{\prime} \mathrm{N}\right.$, $\left.90^{\circ} 17.1^{\prime} \mathrm{W}\right)$, forest litter, Berlese, $1600 \mathrm{~m}$ elev., female, without date, leg. R. Anderson \& J. Ashe \#93-22*1 (KNHM); Nicaragua: Granada Dept., Res. Nat. Volcan Mombacho, entrance rd. $\left(11^{\circ} 50.05^{\prime} \mathrm{N}, 85^{\circ} 58.83^{\prime} \mathrm{W}\right)$, 1060 m elevation, flight intercept trap, male, 1.-5.6.2002, leg. R. Brooks, Z. Falin, S. Chatzimanolis \#NIC1BFC02 188 (KNHM); Rio San Juan Dept., 8 km SE El Castillo, Refugio Bartola $\left(10^{\circ} 58.6^{\prime} \mathrm{N}, 84^{\circ} 20.4^{\prime} \mathrm{W}\right)$, rainforest litter, $30 \mathrm{~m}$ elev., 2 females, 24.-31.5.2002, leg. R. Anderson \#RSA2002-031 (KNHM); same location $\left(10^{\circ} 58.4^{\prime} \mathrm{N}\right.$, $\left.84^{\circ} 20.3^{\prime} \mathrm{W}\right)$, mercury vapor UV light, female, 30.5.2002, leg. R. Brooks, Z. Falin, S. Chatzimanolis \#NIC1BFC02 129 (KNHM); Costa Rica: Park National Rincón de la Vieja, Circle path $\left(10^{\circ} 46.31^{\prime} \mathrm{N}, 85^{\circ} 20.48^{\prime} \mathrm{W}\right), 790 \mathrm{~m}$ elevation, dry forest, 2 males, litter and fruits, sifted, 1 female, litter near creek, sifted, 5.12.2012, leg. M. Schülke (2 MSC, 1 UIC); Rincon de Vieja, Rd. Hacienda, Guachipilin > Santa Maria > Liberia $\left(85^{\circ} 22.45^{\prime}-20.02^{\prime} \mathrm{W}, \quad 10^{\circ} 38.21^{\prime}-45.10^{\prime} \mathrm{N}\right), \quad 170-750 \mathrm{~m}$ elevation, car net, farmland \& dry forest, female, 6.12.2012, leg. Schülke \& Grünberg (MSC); same location and same collectors, but 520-700 m elevation, 8 females, 4.12.2012 (7 MSC, 1 UIC); Puntarenas, Monte Verde, $1400 \mathrm{~m}$ elevation, collected by flight intercept trap, 3 males, 8 females, \#174, from leaf litter \& fruit fall, female, \#031, 5.5.1989, collected by flight 
intercept trap, 1 male, 2 female, \#311, 21.5.1989; moss covered rock, $1420 \mathrm{~m}$ elevation, male \#187, 14.5.1889, leg. J. Ashe, R. Brooks, R. Leschen (10 KNHM, 6 UIC); same location and same collectors, but Rio Guacimal, 1420 m elevation, male, \#198, collected by washing biophytes on rocks, 3 females \#202, 15.5.1989, (3 KNHM, 1 UIC); same location and same collectors, $1570 \mathrm{~m}$ elevation, collected by berlese method, female \#325, 16.5.1989, leaf \& bark litter, female \#142, 11.5.1989, $1280 \mathrm{~m}$ elevation, 3 males, 1 female \#197, 14.5.1989 (KNHM); same location and same collectors, but Boehme house, collected by flight intercept trap, 1400 m elevation, male \#146, 13.5.1989, (KNHM); Rio San Luis $\left(85^{\circ} 48^{\prime} \mathrm{W}, 10^{\circ} 17^{\prime} \mathrm{N}\right), 850 \mathrm{~m}$ elevation, moist forest, leaf litter sample, 2 males \#2088-5, 18.5.1989. leg. J. Longino (1 KNHM, 1 UIC); Guanacaste, Cacao Biol. Station $\left(85^{\circ} 27^{\prime} \mathrm{W}, 10^{\circ} 56^{\prime} \mathrm{N}\right), 1100-1200 \mathrm{~m}$ elevation, leaf litter, collected by berlese method, female, 4.5.1995, leg. R. Anderson (KNHM); Guanacaste, Palo Verde Biological Station Sendero Natural La Venada $\left(10^{\circ} 20.56^{\prime} \mathrm{N}\right.$, $\left.85^{\circ} 19.53^{\prime} \mathrm{W}\right), 10 \mathrm{~m}$ elev., fogging fungus covered log, female, 16.7.2000, leg. J. Ashe, R. Brooks, Z. Falin \#CR1ABF00148 (KNHM); San José, Rabo de Mico, 1800 m elev., male, 6.-8.2.1943, leg. A. Bierig (FMNH); Panama: Colon, Parque National Soberania, Pipeline Rd. km $8.8\left(9^{\circ} 07^{\prime} \mathrm{N}, 79^{\circ} 45^{\prime} \mathrm{W}\right)$, Atta retuse pile, female, 20.5.1995, leg. J. Jolly, C. Chaboo (KNHM); Veraguas Prov., Paris $\left(80^{\circ} 53.2^{\prime} \mathrm{W}, 8^{\circ} 11.2^{\prime} \mathrm{N}\right)$, coastal swamp, sifted, 1 male, 8 females, 1.8.2014, leg. T. Struyve (5 TSC, 4 UIC); Canal Zone, $12 \mathrm{mi}$ NW Gamboa, Rio Agua Salud, male, 19.2.1976, leg. A. Newton (FMNH); Chiriqui Prov., Cerro Colorado, 1290 m elev. floor litter pocket nr. tree, 2 males, 10.1.1981, leg. W. Suter (FMNH); Cuba: Aspiro, 4 males, 10.10.1935, leg. A. Bierig (FMNH); same location, male, 10.1934, leg. A. Bierig (AMNH); Sierra Rangel, 2 females, 5.1937, 12.1934, leg. A. Bierig (FMNH); Habana-Veolado, female, 6.1930, leg. A. Bierig (FMNH); Habana, El Bosque, female, 6.11.1938. leg. A. Bierig (FMNH); Jamaica: Montego Bay, male, 21.5.1975, leg. D. Miller (AMNH); Guadeloupe: without further date, 1 male, 1 female, coll. Plason (FMNH); Gourbyre, without more data, 10 females (AMNH); Dominica: Long Ditton, female, 21.6.1911 (AMNH); Saint Vincent: male, leg. Smith (NMW); Grenada: Belleview Est. (Windward side), 1 male, 1 female, without date, leg. H.H. Smith (FMNH); Vendome Est. (Leeward side), male, leg. H.H. Smith (NMW); Balthazar (Windward side), 3 females, 1 male, leg. H.H. Smith (NMW); female, without more data, leg. H.H. Smith (NMW); Guyana: Essequibo Prov., Little Takutu River, at main road from logging compound, light trap, female, 15.8.1983, leg. K. Schmidt (AMNH); French Guiana: Caussade $\left(52^{\circ} 57^{\prime} \mathrm{W}, 5^{\circ} 10^{\prime} \mathrm{N}\right)$, car net, female, 7.11.2011, leg. T. Struyve (TSC); Bolivia: Santa Cruz Dept., Saavedra Agr. Exp. St., blacklight trap, 1 male, 4 females, 28.12.1959, leg. B. Cumming (FMNH); Beni, Reyes, 20.12.1956, female, leg. L. Pena (FMNH); Brazil: Ceará,
Barbalha, at light, 3 males, 8 females, May 1969, leg. M. Alvarenga (10 AMNH, 1 UIC); Mato Grosso do Sul, Corumbá, without further data, male, (FMNH); Santa Catarina, without further data, female, coll. K. Brancsik (FMNH); Santa Catarina, Blumenau, 2 males, 1 female, leg. Reichensperger (NMW); Paraguay: Dep. Central, Lambaré, 3 males, 10 females, 22.1.1991, female, 30.1.1991, leg. U. Drechsel (11 KNHM, 3 UIC); Dep. Guairá, Colonia Independencia, female, 30.12.1990, leg. U. Drechsel (KNHM); Guairá, Calle Florida, collected at light, 3 females, 8.-10.12.1994, 2 females, 6.1.1994, 1 female, 7.2.1994, leg. U. Drechsel (KNHM); Guariá, Melgarejo, Tacuara Creek, gallery forest, collected by flight intercept trap, female, 11.12.1994, 2 females, flood detritus, 20.10.1994, leg. U. Drechsel (KNHM); Dep. Misiones, Ayolas, female, 17.4.1990, leg. U. Drechsel (KNHM); Alto Paraguay, Madrejon, collected at light, 5 males, 4 females 15 . and 16.5.1995, leg. U. Drechsel (7 KNHM, 2 UIC); Boqueron, Transchaco Hwy., km 430, collected at light, 1 male, 4 females, 19.-28.4.1995, leg. U. Drechsel (4 KNHM, 1 UIC); Paraguari, Sapucai $\left(56^{\circ} 55^{\prime} \mathrm{W}\right.$, $25^{\circ} 40^{\prime}$ S), 190 m elevation, 1 male, 5 females, 4.-8.2.1995, leg. U. Drechsel (5 KNHM, 1 UIC); Caninddeyu, Maracana, primary forest, collected at light, 1 male, 1 female, 24.-30.1.1995, leg. U. Drechsel (1 KNHM, 1 UIC); Puerto Celia (?), without further data, 1 male, 1 female, leg. A. Porta, (FMNH); without further data, male (FMNH); Argentina: Arroyo de Zanjon, NNE San Pedro $\left(24^{\circ} 07^{\prime} \mathrm{S}, 6^{\circ} 50^{\prime} \mathrm{W}\right)$, leaf litter, $460 \mathrm{~m}$ elev., 2 females, 11.11.1995, leg. L. Herman (AMNH);

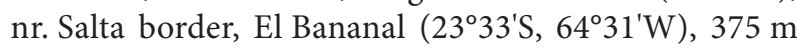
elev., female, 13.11.1995, leg. L. Herman, (AMNH); Catamarca Prov., S. of La Viña $\left(28^{\circ} 03^{\prime} \mathrm{S}, 65^{\circ} 35^{\prime} \mathrm{W}\right)$, $610 \mathrm{~m}$ elev., 1 male, 11 females, 21.11.1995, leg. L. Herman \#2893-28-96 (11 AMNH, 1 UIC); N of

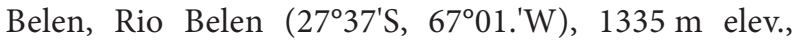
female, 8.11.1995, leg. L. Herman \#2847-2848 (AMNH); $8 \mathrm{~km} \mathrm{~W}$ Londres $\left(27^{\circ} 41^{\prime} \mathrm{S}, 67^{\circ} 12^{\prime} \mathrm{W}\right), 1480 \mathrm{~m}$ elev., female, 7.11.1995, leg. L. Herman (AMNH); San Luis Prov., Quebrada Lopez, 7 km S San Francisco de Monte de Oro $\left(32^{\circ} 30.37^{\prime} \mathrm{S}, 66^{\circ} 07.46^{\prime} \mathrm{W}\right)$, litter near stream, $1000 \mathrm{~m}$ elev., 3 males, 2 females, 3.12.2000, leg. L. Herman (4 AMNH, 1 UIC); same region, Villa de la

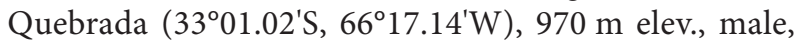
3.12.2000, leg. L. Herman (AMNH); Juyuy Prov., Calilegua, Calilegua Nat. Pk. $\left(23^{\circ} 40.41^{\prime} S, 64^{\circ} 55.34^{\prime} \mathrm{W}\right)$, cloud forest leaf litter, $1640 \mathrm{~m}$ elev., 3 males, 7 females, 20.10.1994, leg. J.M. Carpenter \& D. Agosti (9 AMNH, 2 UIC); La Roja Prov., $10 \mathrm{~km} \mathrm{~W} \mathrm{Olta,} \mathrm{Rio} \mathrm{Olta}$ $\left(30^{\circ} 33.32^{\prime} \mathrm{S}, 6^{\circ} 21.11^{\prime} \mathrm{W}\right)$, litter, $750 \mathrm{~m}$ elev., male, 14.12.2000, leg. L. Herman (AMNH); Salta Prov., 3 km W Baños (2550'S, 64 $\left.56^{\circ} \mathrm{W}\right), 790 \mathrm{~m}$ elev., leaf litter, female, 19.11.1995, leg. L. Herman \#2882-2883 (AMNH); San Juan Prov., N. Astica, Las Tumanas $\left(30^{\circ} 52^{\prime} \mathrm{S}, 67^{\circ} 21^{\prime} \mathrm{W}\right)$, litter near stream, $780 \mathrm{~m}$ elev., 2 females, 4.-5.11.1995, leg. L. Herman (AMNH); Buenos Aires, 1 female, August 1920, leg. F. Schade 
(NMW); Buenos Aires, 1 female, 10.3.1899, leg. C. Bruch (NMW).

Diagnosis: D. schaumii seems to be the most widely distributed species of the genus Diochus in the Neotropic and Nearctic region. It is known from USA up to the region of New York in the North to Argentina in the South. It is characterised by the small head and the slightly widened apex of the paramere. The small head is also found in D. argentinae. Differences to this species are noted there.

Description: Length: 4.1-4.2 mm. Colouration: dark brown; pronotum and posterior margin of elytra light brown; legs and antennae dark yellow with antennomeres three to eleven darker.

Head: $0.52 \mathrm{~mm}$ long, $0.41 \mathrm{~mm}$ wide; eyes large and slightly prominent; temples nearly twice as long as eyes; $\mathrm{EL}: \mathrm{HL}=0.27$; temples nearly parallel; $\mathrm{PW}: \mathrm{EW}=1.06$; posterior angles widely rounded to neck; neck one third as wide as width of head; setiferous punctation deep; adjacent to impunctate midline with posteriorly divergent line of punctures; lateral to medial line with several irregularly large punctures, partly forming irregular lines; postocular area more densely punctate; extremely weak microsculpture with narrow transverse meshes; surface slightly shiny.

Antennae as long as head and one third of pronotum combined; conical antennomeres one to three distinctly elongate; length slightly decreasing from one to three; at least twice as long as apical width of each antennomere; following antennomeres shorter and of decreasing length; fourth antennomere one third longer than wide; tenth nearly quadrate; all antennomeres pubescent; basal antennomeres with moderately long apical setae.

Pronotum: $0.72 \mathrm{~mm}$ long, $0.56 \mathrm{~mm}$ wide; sides slightly divergent posteriad; lateral margin fine; in dorsal aspect only visible in posterior third; anterior and posterior angles widely rounded; setiferous punctation moderately deep; row of three punctures adjacent to impunctate midline; interstice between apical pair of punctures slightly more than twice as wide as between posterior pairs of punctures; laterad with few punctures; number of punctures irregular; varying between two and five; surface polished without microsculpture.

Elytra: $0.72 \mathrm{~mm}$ long, $0.75 \mathrm{~mm}$ wide; slightly divergent to posterior margin; shoulders distinct, but obtusely angled; posterior margin slightly concave; disc with four irregular rows of setiferous punctures; with weakly coriaceous ground sculpture; surface slightly shiny.

Abdomen densely pubescent.

Aedeagus elongate; seminal vesical of endophallus three third as long as central lobe; basal inner duct looped; apically with irregular forceps; paramere nearly as long as central lobe; paramere elongate; apex shortly widened to spoon-shaped expansion with pair of two setae on one side and one seta on other side.
Spermatheca $0.25 \mathrm{~mm}$ long, $0.16 \mathrm{~mm}$ wide; bursa copulatrix in lateral position to coiled duct; coiled duct with numerous partly irregular coils.

\section{Diochus verhaaghi-group \\ Diochus verhaaghi spec. nov.

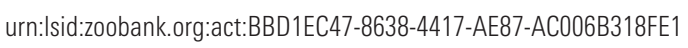 Figs $32 \mathrm{~A}-\mathrm{C}, 40 \mathrm{E}, 44 \mathrm{H}$}

Type material: male, Holotype: Peru: Huanuco, Panguana Station $\left(74^{\circ} 56^{\prime} \mathrm{W}, 9^{\circ} 37^{\prime} \mathrm{S}\right)$, pitfall trap, 10.-24.10.1984, leg. M. Verhaagh, \#GuU (UIC).

Paratypes: Mexico: Camp.ElTormento, $6 \mathrm{~km}$ W Escarcega, evergreen trop. forest, fungi \& litter, Berlese, 23.7.1983, leg. S. \& J. Peck (FMNH); Cost Rica: Puntarenas, Monte Verde, from Xylaria, 1550 m elev., female, 25.5.1989, leg. J. Ashe, R. Brooks, R. Leschen (KNHM); OSA Peninsula, $5 \mathrm{~km}$ W Rincon de Osa $\left(83^{\circ} 31^{\prime} \mathrm{W}, 8^{\circ} 42^{\prime} \mathrm{N}\right), 50 \mathrm{~m}$ elev., Berlese, log, under bark, $45^{\circ}$ lean in stream bed, forest covered, 3 males, 4 females, 24.-30.3.1973, leg. J. Wagner \& J. Kethley (FMNH); OTS, Sta, finca Las Cruces, San Vito $\left(82^{\circ} 58^{\prime} \mathrm{W}, 8^{\circ} 46^{\prime} \mathrm{N}\right), 4000 \mathrm{ft}$. elv., Berlese, under bark \& rot. log galleries, old saw mill site, 1 male, 1 female, 19.3.1973, leg. J. Wagner \& J. Kethley (FMNH); same location, but, Berlese, floor litter from Virgin forest moderate slope, 2 males, 1 female, 18.3.1973, leg. J. Wagner \& J. Kethley (FMNH); same location, but loop rd. nr. sawmill, under sawdust, 2 males, 2 females, 14.3.1973, leg. J. Wagner \& J. Kethley (FMNH); Alajuela, E.B. San Ramón, 27 km N \& $8 \mathrm{~km}$ W San Ramón $\left(10^{\circ} 13.4^{\prime} \mathrm{N}, 84^{\circ} 35.46^{\prime} \mathrm{W}\right), 810 \mathrm{~m}$ elev., fogging fungus covered log, female, 7.7.2000, leg. J. Ashe, R. Brooks, Z. Falin \#CR1ABF00068 (KNHM); Heredia, OTS Field Sta. Puero Viejo Sarapiui, Rio Puerto Viejo (83 $\left.59^{\prime} \mathrm{W}, 10^{\circ} 26^{\prime} \mathrm{N}\right)$, Berlese, bromeliad root fibres, cups, axils, 9 males, 12 females, 5.-11.3.1973, leg. J. Wagner \& J. Kethley (19 FMNH, 2 UIC); La Selva Field Sta. OTS, under bark, 2 males, 1 female, 10.3.1973, leg. J. Wagner \& J. Kethley (FMNH); Puerto Viejo de Sarapiqui, La Selva Field Sta., 100 m elev., under bark, male, 7.3.1973, leg. J. Wagner \& J. Kethley (FMNH); Guanacaste, Canas, Miravalles Volcano $\left(82^{\circ} 7^{\prime} \mathrm{W}, 10^{\circ} 42^{\prime} \mathrm{N}\right)$, Berlese, bark mixed log mold, 4 males, 10 females, 8.4.1973, leg. J. Wagner \& J. Kethley (12 FMNH, 2 UIC); Comelco, Palo Verde, OTS $9 \mathrm{~km}$ W Bagaces $\left(85^{\circ} 18^{\prime} \mathrm{W}\right.$, $\left.10^{\circ} 32^{\prime} \mathrm{N}\right), 40 \mathrm{~m}$ elev., Berlese, log mold, bark + fungi, female, 9.4.1973, leg. J. Wagner \& J. Kethley (FMNH); Las Mercedes, 22.12.1922, leg. Nevermann (FMNH); S.M. de Barranca, female, 12.-16.2.1940, leg. Bierig (FMNH); Panama: Canal Zone, Barro Colorado Is., litter under rotting logs, litter under old tree and vine fall, wet leaves and debris, forest stream, litter under fungusy logs, under bark rotting logs, 11 males, 13 females, 4.2., 6.2., 12.2., 13.2., 25.2., 27.2.1976, leg. A. Newton (22 FMNH, 2 UIC); same location, but Berlese, debris in rotten hollow stub, male, 24.1.1959, leg. H.S. Dybas (FMNH); $4.1 \mathrm{mi}$. NW Gamboa, Rio Frijoles, flood debris and wet 
leaves along river, 2 females, 19.2.1976, leg. A. Newton (FMNH); Panama Prov., Altos de Majé, Berlese, debris at base of palmetto leaves, rotten wood in old forest, center of rotten palm, 2 males, 1 female, 6.-15.10.1975, leg. D.S. Chandler (FMNH); Cerro Azul, $2000 \mathrm{ft}$. elev., Daedalea elegans, female, 21.-22.6.1976, leg. A. Newton (FMNH); Cerro Campana, 3200 ft. elev., Berlese, cloud forest leaf litter, 3 males, 1 female, 14., 23.2.1976, leg. A. Newton (FMNH); Las Cumbres, UV light, female, 26.12.1975, leg. H. Wolda (FMNH); Coclé, El Valle, trail to Las Minas from "La Mera" 2400-2600 ft. elev., Berlese, thatch from nest of snapping ant along trail, male, 21.2.1959, leg. H.S. Dybas (FMNH); same location, but $2500 \mathrm{ft}$. elev., log debris, male, 22.2.1959, leg. H.S. Dybas (FMNH); Chririqui Prov., Boquete, sifted, coffee tree litter, male, 2.10.1975, leg. D.S. Chandler, (FMNH); trail to Cerro Colorado peak, $1490 \mathrm{~m}$ elev., litter damp pocket, Sphagnum, 2 females, 23.1.1981, leg. W. Suter (FMNH); Cerro Colorado, $1290 \mathrm{~m}$ elev., wet basal pseudo-fork between small trees, litter of stage III stump, semidry, litter of upright log with polypores, floor litter pocket nr. tree, 4 females, 10.1.1981, 13.1.1981, leg. W. Suter (FMNH); Bocas del Toro Prov., Cerro Colorado, Qda, 3w, 1490 m elev., woody slash, clearing, 4 females, 1.11.1981, W. Suter (FMNH); French Guiana: nr. Eaux Claires, $3.5 \mathrm{mi} \mathrm{N}$ Saül $\left(3^{\circ} 38-40^{\prime} \mathrm{N}, 53^{\circ} 13-14^{\prime} \mathrm{W}\right)$, leaf litter near stream, 155-200 m elev., 3 males, 4 females, 5.-13.10.1995, leg. L. Herman (AMNH); Saül, under bark, 2 females, March-April 1999, leg. A. Berkov (AMNH); Suriname: Brokopondo, Brownsberg Nature Preserve, Witi Creek Trail $\left(55^{\circ} 10.53^{\prime} \mathrm{W}, 4^{\circ} 56.55^{\prime} \mathrm{N}\right)$, under bark, 1 male, 23.6.1999, leg. Z. Falin \#SUR1F99 98 (KNHM); Ecuador: Esmeraldas, San Francisco $\left(78^{\circ} 41.749^{\prime} \mathrm{W}\right.$, $\left.1^{\circ} 06.454^{\prime} \mathrm{N}\right)$, female, 11.11.2014, leg. Brachat (VAC); Pichincha Prov., W of Alluriquin, Tinalandia, litter near stream, 2600-2800 ft. elev., female, 19.-20.5.1993, leg. L. Herman \#2724-2725 (AMNH); Tinalandia, 16 km SE Sto. Domingo, $680 \mathrm{~m}$ elev., Berlese, leaf litter \& soil, female, 15.6.1975, leg. S. Peck (FMNH); Napo Prov. 25 km W Tena, Tena-Talag Grande road, $2000 \mathrm{ft}$ elev., male, 23.5.1993, leg. L. Herman \#2739 (AMNH); Napo, 69 km NE Baeza, $15 \mathrm{~km}$ SW Reventador, litter, $4600 \mathrm{ft}$ elev., 28.-30.10.1988, leg. L. Herman (AMNH); Peru: same location as holotype, Manioc field, 4 males, 3 females, 4.5.1976, leg. W. Hanagarth, \#186 (6 UIC, 1 MSC); same location and same collector, pasture, pitfall trap, female, 20.5.1976, \#272 M9, (UIC); same location, same collector, cut forest planted with manioc, pitfall trap, male, 4.5.1976, \#181 Sek2 (UIC); same location, Panguana Station at Rio Llullapichis $\left(74^{\circ} 56^{\prime} \mathrm{W}, 9^{\circ} 37^{\prime} \mathrm{S}\right), 260 \mathrm{~m}$ elevation, collected at light, female, 1.-23.10.2010, leg. G. Riedel (VAC); Tambopata, $15 \mathrm{~km}$ NE Pto. Maldonado $\left(69^{\circ} 03^{\prime} \mathrm{W}, 12^{\circ} 33^{\prime} \mathrm{S}\right)$, fungus on log or fungusy log, $200 \mathrm{~m}$ elevation, 8 males, 14 female, 13.6.1989, 13.7.1989, leg. J. Ashe \& R. Leschen, \#501 (20 KNHM, 2 UIC); same location, same date, same collectors, but swamp trail, fungus, 5 males, 7 females (10 KNHM, 2 UIC); same location, same date, same collectors, but rotting tree, male, \#507 (KNHM); same location, same collectors, pile of dead ants, female, 24.6.1989, \#267, female, 6.7.1989, \#417 (KNHM); same location, same collectors, but under leaves by stream, 2 females, 5.7.1989, \#397 (1 KNHM, 1 UIC); same location, same collectors, but woody polypore, 1 male, 1 female \#577, 19.7.1989 (KNHM); same location, but berlese in fruit fall, Plot \#Z1U16, 3 males, 25.6.1989, leg. R.A. Leschen, (2 KNHM, 1 UIC); same location, same date, but Palm flowers, 1 female \#338, flower-fall log, 1 male, 1 female \#400, leg. J. Ashe, R. Leschen (KNHM); same location, same collectors, but log/Irpex-like, female, 10.7.1989, \#489 (KNHM); same location, but compost pile, 1 male, 3 females \#218, 22.6.1989, (KNHM); Loreto, Campamento, San Jacinto (75 $\left.51.77^{\prime} \mathrm{W}, 2^{\circ} 18.75^{\prime} \mathrm{S}\right), 175-215 \mathrm{~m}$ elevation, berlese, female \#1, 2.7.1993, leg. R. Leschen (KNHM); $1.5 \mathrm{~km} \mathrm{~N}$ Teniente Lopez $\left(76^{\circ} 06.92^{\prime} \mathrm{W}, 2^{\circ} 35.66^{\prime} \mathrm{S}\right), 210-240 \mathrm{~m}$ elevation, fruit fall, female \#112, 17.7.1993, leg. R. Leschen (KNHM); Madre do Dios, Tambopata, leaf \& grass litter, 2 male, 6 females, 25., 26., 27.10.1982, leg. L.E. Watrous \& G. Mazureck (FMNH); same location and collectors, 3 females, bamboo litter, 11 males, 18 females, but rotten figs, 28.10.1982 (30 FMNH, 2 UIC); Cuzco Dept., Consuelo, Manu Rd., km 165, litter along stream, female, 4.10.1982, leg. L.E. Watrous \& G. Mazureck (FMNH); Bolivia: Santa Cruz Dept., 3.7 km SSE Buena Vista Hotel Flora y Fauna $\left(63^{\circ} 33.15^{\prime} \mathrm{W}, 1^{\circ} 29.95^{\prime} \mathrm{S}\right), \quad 400-440 \mathrm{~m}$ elevation, primary forest flood debris, 1 male, 1 female, 7.11.2002, leg. R. Leschen \#BOL1L02-41 (KNHM); El Beni, Beni Stn., Palm Camp., NE San Borja, under bark, female, 30.7.1988, leg. R.W. Brooks, BIOLAT-SI/MAB, larvae in ETOH coll'n (KNHM); Brazil: Minas Gerais, Paso Quatro, 2 males, leg. Reichensperger (NMW).

Diagnosis: The species is mainly differentiated by the typical structure of the aedeagus with slender parameres and seminal vesical of endophallus. Within the species group, it is characterised by the smaller size, the small eyes, and the distinctly divergent head, compared to the larger $D$. santacatarinae with approximately parallel head. Regarding the small size, $D$. verhaaghi resembles the species of the D. nanus-group. It can be distinguished from those species by the darker head and the smaller eyes.

Description: Length: $2.7-3.0 \mathrm{~mm}$. Colouration: eddish brown; head dark brown, nearly black; legs and antennae yellow; antennomeres four to eleven slightly darker; posterior margin of abdominal segments light brown.

Head: $0.41 \mathrm{~mm}$ long, $0.34 \mathrm{~mm}$ wide; eyes not prominent; small; temples nearly three times as long as eyes; $\mathrm{EL}: \mathrm{HL}=0.19$; temples distinctly divergent posteriad; $\mathrm{PW}: \mathrm{EW}=1.40$; posterior angles rounded, but nearly rectangular; posterior margin straight; neck only one fourth of head's width; setiferous punctation moderately deep and sparse; adjacent to wide impunctate midline with row of four to five punctures; laterad to medial rows with few sparse punctures; postocular area with 
slightly denser punctation; without microsculpture; surface polished.

Antenna as long as head and half of pronotum combined; first antennomere thick and nearly as longer as following two antennomeres; second and third antennomere conical; second slightly thicker than third; second twice as long as its apical width; third only 1.5 times as long as its apical width; following antennomeres shorter; wider than long; antennomeres five to nine twice as wide as long; all antennomeres pubescent; basal antennomeres with setae.

Pronotum: $0.53 \mathrm{~mm}$ long, $0.42 \mathrm{~mm}$ wide; sides approximately parallel; anterior and posterior angles widely rounded; lateral margin fine; in dorsal aspect visible in posterior half; setiferous punctation moderately deep and very sparse; adjacent to wide impunctate midline with row of three punctures; interstice between anterior pair of punctures more than twice as wide as interstices between two posterior pairs; laterad to medial row of punctures two to three irregular punctures; without microsculpture, but with very sparse micro-punctures; surface polished.

Elytra: $0.46 \mathrm{~mm}$ long, $0.53 \mathrm{~mm}$ wide; sides distinctly divergent to posterior angles; shoulders distinct; obtusely angulate; posterior margin deeply emarginate; setiferous punctation in irregular longitudinal rows; first row adjacent to suture with four to five punctures; laterad two more rows on disc; with weak coriaceous ground sculpture; surface slightly less shiny than pronotum.

Abdomen densely pubescent.

Aedeagus broad; slender seminal vesical of endophallus diagonal; basal inner duct shortly looped; ending in irregular forceps; paramere slender; shorter than central lobe; narrow shaft widened to slight apical expansion pointing transversely; at apex with four fine setae; in apical half with few sensillae.

Spermatheca $0.28 \mathrm{~mm}$ long, $0.23 \mathrm{~mm}$ wide; bursa copulatrix in lateral position to coiled approximately circular duct; numerous coils of duct irregularly coiled.

Etymology: The species is named to honour one of the collectors, Dr. Manfred Verhaagh, of the Natural History Museum, Karlsruhe, Germany.

Diochus santacatarinae spec. nov.

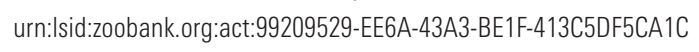
Figs $33 \mathrm{~A}-\mathrm{C}, 40 \mathrm{~F}, 45 \mathrm{~A}$

Type material: male, Holotype: Brazil: Santa Catarina (plate with Korge's determination: Diochus tarsalis) (SDEI). Paratypes: Brazil: Santa Catarina, 21 males, 15 females, leg. Klimsch (6 FMNH, 2 AMNH, 27 NMW); Nova Teutonia, female, leg. Plauman (FMNH); same location, but $27^{\circ} 11^{\prime} \mathrm{S}, 52^{\circ} 23^{\prime} \mathrm{W}$, female, 3.1954, leg. F. Plaumann (FMNH); French Guiana: Coralie $\left(52^{\circ} 21^{\prime} \mathrm{W}, 4^{\circ} 30^{\prime} \mathrm{N}\right)$, car net, 1 male, 2 females, 15.11.2011, leg. T. Struyve (UIC); Barrage de Petit Saude $\left(53^{\circ} 02^{\prime} \mathrm{W}, 5^{\circ} 03^{\prime} \mathrm{N}\right)$, car net, male, female, 15.11.2011, leg. T. Struyve (TSC); Ecuador: Napo Prov., 25 km W Tena, Tena-Talag Grande road, litter nr. steam, 2000 ft. elev., male, 23.5.1993, leg. L. Herman \#2739 (AMNH); Peru: Cuzco Dept., Consuelo, Manu rd. km 165, leaf litter, 2 males, 6.10.1982, leg. L.E. Watrous \& G. Mazurek (FMNH); same location, but litter under crown of felled tree, female, 2.10.1982, leg. L.E. Watrous \& G. Mazurek (FMNH); same location, but leaf litter, 1 male, 3 females, 7.10.1982, leg. L.E. Watrous \& G. Mazurek (FMNH); same location, but litter along stream, 1 male, 1 female, 5.10.1982, leg. L.E. Watrous \& G. Mazurek (FMNH).

Diagnosis: The aedeagus of the species closely resembles that of $D$. verhaaghi, in particular, regarding the triangular apical process of the parameres. In D. santacatarinae, the apical setae are much longer than in $D$. verhaaghi, the apex of the apical process is more acute and the number of sensillae is smaller and they are locate closer to the base of the shaft. D. santacatarinae is distinctly larger than D. verhaaghi. In this respect it is similar to many other species of the D. inornatus- or D. schaumii-group of the same size.

Description: Length: $3.6 \mathrm{~mm}$. Colouration: dark brown; pronotum slightly lighter brown; legs and antennae as light brown as pronotum with antennomeres four to ten dark brown.

Head: $0.56 \mathrm{~mm}$ long, $0.43 \mathrm{~mm}$ wide; eyes slightly prominent; temples 1.9 times as long as eyes; $\mathrm{EL}: \mathrm{HL}=0.22$; temples slightly divergent posteriad, $\mathrm{PW}: \mathrm{EW}=1.15$, posterior angles widely rounded; posterior margin convex; setiferous punctation deep and dense; clypeus densely punctate; partly coriaceous; vertex with small impunctate midline; convergent row of four punctures from anterior edge of eyes to middle of vertex; another curved row of setiferous punctures on supraocular area laterad to medial row; on postocular area and at posterior marginal area several more setiferous punctures; between setiferous punctures with sparse micro-punctures; without microsculpture; surface polished.

Antennae as long as head and half of pronotum combined; first antennomere thicker and longer than remaining antennomeres; more than twice as long as wide; second and third antennomere conical; twice as long as its apical width; third slightly shorter and narrower than second; following antennomeres distinctly shorter than basic three antennomeres; fourth antennomere slightly longer than wide; tenth antennomere 1.5 times wider than long; all antennomeres pubescent and with apical setae.

Pronotum: $0.63 \mathrm{~mm}$ long, $0.54 \mathrm{~mm}$ wide; sides nearly parallel; anterior angles widely rounded; in anterior third, strongly convergent; posterior angles shortly rounded; lateral margin fine; in dorsal aspect, visible in posterior half; posterior margin slightly convex; setiferous punctation sparse and deep; along impunctate midline three pairs of punctures; interstice between 
anterior pair twice as wide as interstices between posterior pairs; laterad, two to three additional punctures; several setiferous punctures along lateral margin; between large setiferous punctures with sparse micropunctation; surface polished.

Elytra: $0.67 \mathrm{~mm}$ long, $0.75 \mathrm{~mm}$ wide; sides divergent to posterior margin; shoulders obtuse; posterior angles approximately rectangular; posterior margin slightly emarginate; setiferous punctures in irregular rows; first row of five punctures adjacent to suture line; two additional rows laterad; interstice between two rows on disc much closer than between row at suture and first row on disc; ground sculpture weakly coriaceous; surface less shiny than pronotum or head.

Abdomen densely pubescent.

Aedeagus broad; seminal vesical of endophallus diagonal; slender; 0.6 times as long as central lobe; basal inner duct shortly looped; with complex sclerotised apical forceps; central lobe with two long hooks at apex; paramere slender; at apex widened to slender triangular process; four long setae at apical edge; shortly in front of widening with smoothly rounded lateral process; three sensillae at basal shaft.

Spermatheca $0.27 \mathrm{~mm}$ long, $0.16 \mathrm{~mm}$ wide; bursa copulatrix outside coiled duct; coiled duct with only very few approximately circular coils.

Etymology: The name of the species derived from the Brazilian State Santa Catarina, where the holotype was found.

\section{Diochus nanus-group}

\section{Diochus apicipennis CAMERON, 1922 \\ Figs 37A-C, 40J, 45E}

Diochus apicipennis CAMERon, 1922: 116

Type material examined: Syntypes: Saint Vincent: W.I., male, aedeagus lost, female, leg. H.H. Smith, \#94, \#151 $(\mathrm{BMNH})$.

Additional material examined: Saint Vincent: Leeward side, male, leg. H.H. Smith (NMW); Guadeloupe: Gourbyre, Acc. 4860, 4 males, 14 females, without more data (16 AMNH, 2 UIC).

Diagnosis: The four species of the D. nanus-group are very similar and hardly to distinguish without section of the aedeagus. The eyes of D. apicipennis are slightly shorter than in the other three species with EL : HL ratio of 0.21 ( 0.28 in the other species). The species can be clearly distinguished from the other three species by the structure of the paramere. Whereas the apical margin of the widened plate of the paramere is convex, the margin is distinctly emarginate and separated into two lobes in the three other species.
Description: Length: $2.8 \mathrm{~mm}$. Colouration: yellow; posterior third of elytra brown; abdomen dark yellow to brownish; legs and antennae light yellow; antennomeres four to ten slightly darker.

Head: $0.41 \mathrm{~mm}$ long, $0.38 \mathrm{~mm}$ wide; eyes not prominent; small; $\mathrm{EL}: \mathrm{HL}=0.21$; temples distinctly divergent posteriad; $\mathrm{PW}$ : AW 1.23; setiferous punctation moderately deep and dense; adjacent to wide impunctate midline with line of three punctures; between medial line and eyes another convergent line of five to six punctures; temples sparsely punctate; without microsculpture; surface polished.

Antennae as long as head and half of pronotum combined; first antennomere slightly thicker than following antennomeres; second and third antennomere conical; nearly twice as long as its apical width; following antennomeres increasing in width; fourth antennomere quadrate; tenth antennomere nearly twice as wide as long; all antennomeres pubescent; basal three antennomeres with short setae.

Pronotum: $0.47 \mathrm{~mm}$ long, $0.41 \mathrm{~mm}$ wide; parallel; anterior third nearly semi-circular; posterior angles obtusely rounded; lateral margin fine; in dorsal aspect, visible in posterior third; setiferous punctation sparse; adjacent to wide impunctate midline with row of three punctures; interstice between anterior pair more than twice as wide as between posterior pairs; few setiferous punctures laterad; along lateral margin several setiferous punctures; without microsculpture; surface polished.

Elytra: $0.50 \mathrm{~mm}$ long, $0.53 \mathrm{~mm}$ wide; sides slightly divergent to posterior angles; shoulders obtusely rounded; posterior angles nearly rectangular; setiferous punctation moderately deep and dense; in irregular rows; first row adjacent to suture line with eight punctures; laterad three additional rows of five to six punctures; without microsculpture, but weak coriaceous ground-sculpture; surface less shiny than that of head and pronotum.

Abdomen densely pubescent.

Aedeagus with moderately thick; seminal vesical of endophallus 0.7 times as long as total length of central lobe; basal inner duct looped; ending into sclerotised forceps; apically with sclerotised hooks; paramere with slender shaft; anterior half widened to uniform plate; plate at one side with transparent lobe; at apical margin of plate, one long seta and two setae (one long and one short) at opposite angles; several sensillae along margin from widened part to basal shaft.

Spermatheca $0.28 \mathrm{~mm}$ long, $0.22 \mathrm{~mm}$ wide; bursa copulatrix in lateral position to coiled approximately circular duct; duct irregularly coiled with few coils.

\section{Diochus nanus ERICHSON, 1839}

Figs 35A-C, 40I, 45D

Type material examined: female, Lectotype: Columbia, without more data, coll. Moritz (ZMHB).

Paralectotype: female, with same data as lectotype (ZMHB). 

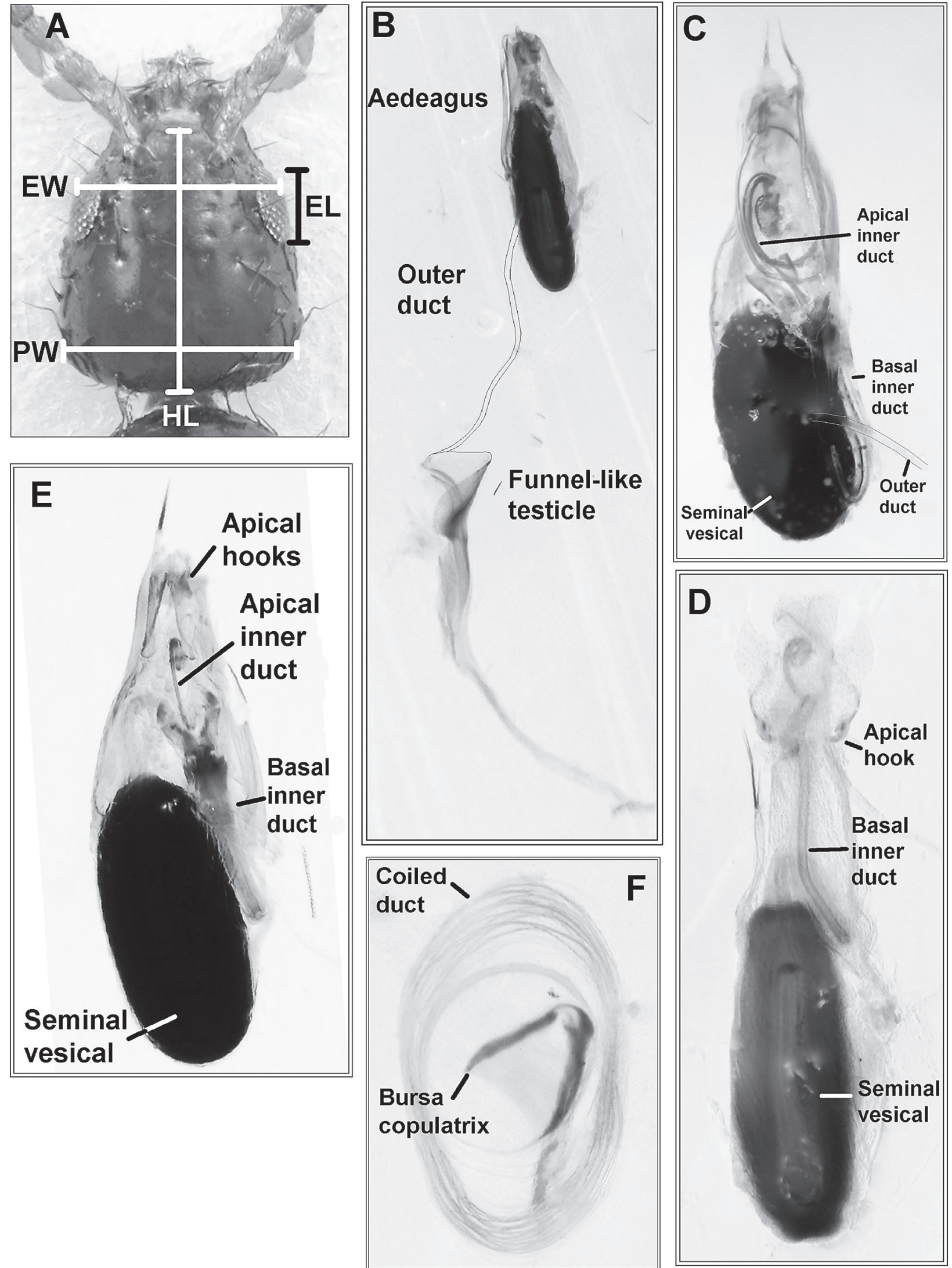

Fig. 1: Head of Diochus maculicollis showing measurements to indicate relative length of eyes and posterior divergence of head (A); Male copulatory organs of D. perplexus (B); inner organs of aedeagus of D. longicornis (C); ejected aedeagus of $D$. perplexus without funnel-like widening of basal duct (D); aedeagus of D. newtoni with funnel-like widening of basal duct (E); female copulatory organs of D. longicornis (F). 
Additional material examined: Costa Rica: Heredia, $3 \mathrm{~km}$ S. Puerto Viejo, OTS-La Selva $\left(84^{\circ} 01^{\prime} \mathrm{W}, 10^{\circ} 26^{\prime} \mathrm{N}\right)$, $100 \mathrm{~m}$ elevation, 2 females, Sept. 1992, leg. P. Hanson (KNHM); Rd. Barrigones (Osa), > Chacarita $\left(83^{\circ} 15^{\prime}-\right.$ $\left.26^{\prime} \mathrm{W}, 8^{\circ} 36^{\prime}-48^{\prime} \mathrm{N}\right), 0-250 \mathrm{~m}$ elevation, pastures, plantages, devastated forest, car net, 1 male, 3 females, 11.12.2012, leg. Schülke \& Grünberg (1 MSC, 3 UIC); S Rincon de la Vieja, Rd. Hacienda Guachipilin > Santa Maria $\left(85^{\circ} 20.15^{\prime}-22.45^{\prime} \mathrm{W}, 10^{\circ} 42.43^{\prime}-45.10^{\prime} \mathrm{N}\right), 520-700 \mathrm{~m}$ elevation, car net, farmland \& dry forest, 1 male, 2 females, 4.12.2012, leg. Schülke \& Grünberg (UIC); Osa Peninsula, Rd. Bahia Drake > Rincon de Osa $\left(83^{\circ} 29^{\prime}-40^{\prime} \mathrm{W}\right.$, $\left.8^{\circ} 41^{\prime}-42^{\prime} \mathrm{N}\right), 0-400 \mathrm{~m}$ elevation, car net, devastated forest \& plantations, 1 male, 2 female, 9.12.2012, leg. Schülke \& Grünberg (MSC); Alajuela Prov., Rd. Colonia Puntarenas $>$ Rio Negro $\left(84^{\circ} 46^{\prime}-57^{\prime} \mathrm{W}, 10^{\circ} 50^{\prime}-53^{\prime} \mathrm{N}\right), 40-90 \mathrm{~m}$ elevation, fincas, meadows, forest remnants, car net, 1 female, 18.12.2013, leg. Schülke Grünberg (MSC); Guanacaste Prov., Nicoya Peninsula, PN Diria, Area Conservacion Tempisce $\left(85^{\circ} 35.44^{\prime} \mathrm{W}, 10^{\circ} 09.43^{\prime} \mathrm{N}\right)$, river bank and old car track, 2 females, 15.12.2013, L.M. Schülke (1 MSC, 1 UIC); Sardinal, 2 females, 23.2.1941, leg. A. Bierig (FMNH); Pearl Island, San Miguel, 2 females, leg. Champion (FMNH);
Panama: Colon Prov., Maria Chiquita, composted grasses at beach, 1 male, 5 females, 3.1.1981, leg. W. Suter (FMNH); Colombia: Magdalena, Cañaveral (7356'W, $\left.11^{\circ} 19^{\prime} \mathrm{N}\right), 200 \mathrm{~m}$ elevation, leaf litter, male, 11.8.1985, leg. J. Longino \#708 (KNHM); Suriname: Marienburg, sweep from grass, female, 19.5.1916, leg. C.B. Williams (BMNH); Saint Thomas: 3 males, 6 females, without additional data, coll. Kraatz (SDEI); without further data, coll. Eppelsheim, 3 males, 9 females ( $3 \mathrm{FMNH}, 9 \mathrm{NMW}$ ); same location, 7 females, but leg. v. Eggers (NMW).

Diagnosis: D. nanus can be separated from the other species of the group by the less widened paramere. The eyes are as large as in $D$. perplexus and $D$. parvulus. It can be distinguished from $D$. parvulus by the unicoloured elytra and from $D$. perplexus by the deeper microsculpture of the head and the striate microsculpture at the anterior angles of the pronotum.

Description: Length: $2.8 \mathrm{~mm}$. Colouration: light brown to yellowish; abdomen slightly darker brown with posterior margin of abdominal segment lighter; legs and antennae yellow.
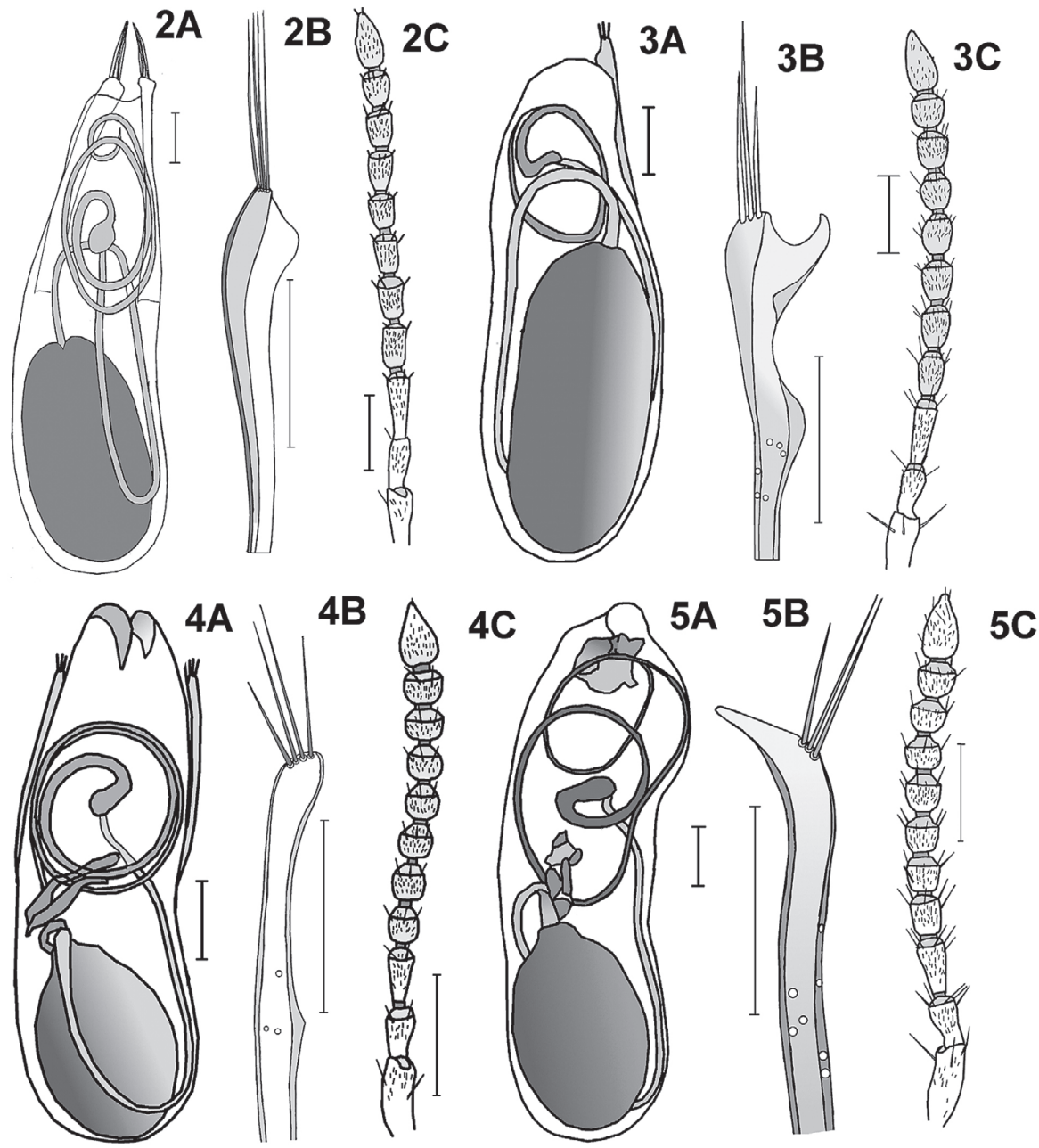

Figs 2-5: Diochus longicornis-group: Diochus longicornis (2), D. tarsalis (3), D. adisi (4), D. guianensis (5); aedeagus (A), paramere (B) and antenna (C); scale bar: A, B: $0.1 \mathrm{~mm}, \mathrm{C}: 0.2 \mathrm{~mm}$. 
Head: $0.40 \mathrm{~mm}$ long, $0.37 \mathrm{~mm}$ wide; eyes slightly prominent; large; temples twice as long as eyes; $\mathrm{EL}: \mathrm{HL}=0.28$; temples slightly divergent posteriad; $\mathrm{PW}: \mathrm{EW}=1.13$; posterior angles widely rounded; posterior margin approximately straight; setiferous punctation moderately deep and dense; wide midline impunctate; adjacent to midline irregular row of three to four punctures; between medial row and eyes two further rows of punctures; postocular area more densely punctate; netlike microsculpture more distinct on clypeus and interocular area; weaker on posterior vertex; surface moderately shiny.

Antennae slightly longer than head; first antennomere longer and thicker than following antennomeres; second antennomere two third as long as first; twice as long as wide; third antennomere conical; only slightly longer than wide; following antennomeres rectangular; wider than long; fourth slightly wider than long; eighth and ninth nearly twice as wide as long; all antennomeres pubescent and with apical setae.

Pronotum: $0.52 \mathrm{~mm}$ long, $0.43 \mathrm{~mm}$ wide; sides approximately parallel; posterior angles widely rounded; posterior and anterior margins nearly semi-circular; lateral margin fine; in dorsal aspect visible in posterior half; setiferous punctation moderately deep and sparse; adjacent to wide impunctate midline with row of three punctures; interstice between anterior pair of punctures one third wider than between posterior pairs of punctures; between inner row and lateral margin few sparse punctures; along lateral margin several punctures; with weak microsculpture in anterior half, surface shiny.

Elytra: $0.52 \mathrm{~mm}$ long, $0.55 \mathrm{~mm}$ wide; shoulders shortly rounded; sides divergent to posterior angles; posterior margin emarginate; setiferous punctures in irregular rows of six to seven punctures; between suture and lateral margin four rows of punctures; ground-sculpture weak; surface moderately shiny.

Abdomen densely pubescent.

Aedeagus elongate; seminal vesical two third as long as central lobe; basal inner duct looped; ending in complex sclerotised forceps; paramere slender; apex obtusely angulate; not projecting central lobe; widened shortly in front of bifurcate apex; each process obtusely rounded; outer process with one short seta; inner process with two short setae; shaft with numerous sensillae.

Spermatheca $0.25 \mathrm{~mm}$ long, $0.15 \mathrm{~mm}$ wide; bursa copulartix in lateral position to coiled duct; coiled duct with irregular approximately oval coils.
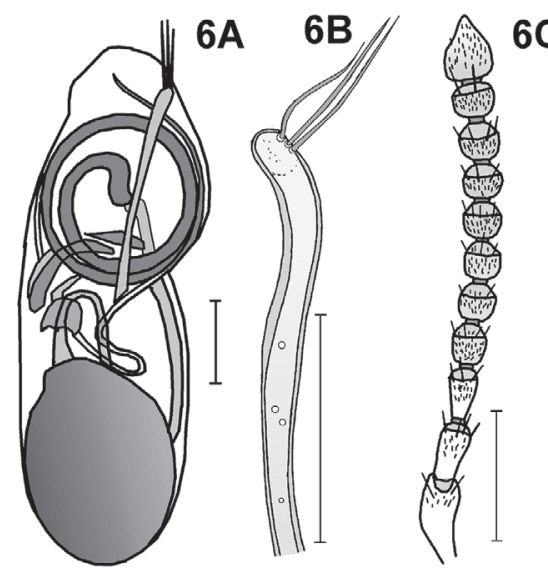

$6 \mathrm{C}$
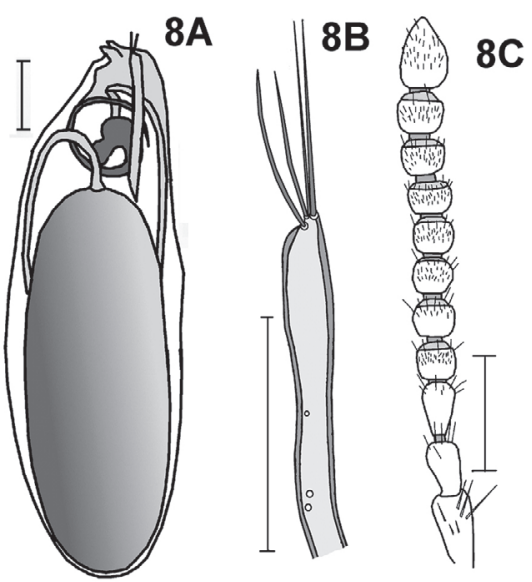
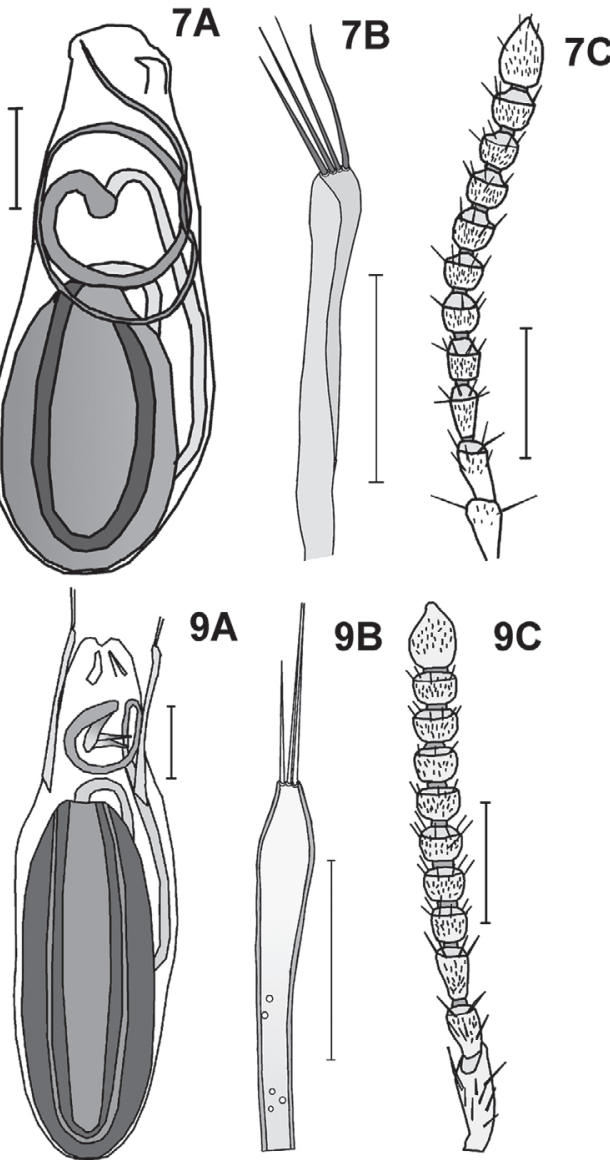

Figs 6-9: Diochus longicornis-group: Diochus ashei (6), D. unicolor (7); Diochus inornatus-group: D. inornatus (8), D. hanagarthi (9); aedeagus (A), paramere (B) and antenna (C); scale bar: A, B: $0.1 \mathrm{~mm}$, C: $0.2 \mathrm{~mm}$. 
Diochus parvulus KRAATZ, 1860

Figs $36 \mathrm{~A}-\mathrm{C}, 40 \mathrm{H}, 45 \mathrm{C}$

Diochus parvulus KraAtz, 1860: 27

Type material examined: male, Holotype: Brazil: Bahia, coll. Kraatz (SDEI).

Further material examined: Venezuela: Trujillo Prov., $60.6 \mathrm{~km} \mathrm{NW}$ Bocono, $1900 \mathrm{ft}$. elev., litter near stream, 2 males, 5 females, 31.3.1992, leg. L. Herman (6 AMNH, 1 UIC); Tinaco, Quebradon, Cojedes, sandy soil on the river bank, $350 \mathrm{~m}$ elev., 3 males, 9.1.1986, leg. M.G. Paoletti (AMNH); Los Chorros, 3 males, 5.1922, leg. F. Psota (FMNH); Ecuador: Sucumbios, Sacha Lodge $\left(76^{\circ} 5^{\prime} \mathrm{W}, 0^{\circ} 5^{\prime} \mathrm{S}\right), 270 \mathrm{~m}$ elevation, malaise trap, female, 3.-13.4.1994, leg. Hibbs (KNHM); Pichincha, Maquipucuna For. Res., 50 km NW Quito, 1300 m elevation, banana dull berlesate, 1 male, 4 females, 3.12.1991, leg. C. Carlton \& R. Leschen (4 KNHM, 1 UIC); Napo Prov., $33 \mathrm{~km} \mathrm{~N}$ Tena, $59 \mathrm{~km}$ E on Loreto Rd., litter nr. stream, 2800 ft. elev., 5 males, 2 females, 4.11.1988, leg. L. Herman (AMNH); Napo Prov., Limoncocha, 250 m elev., Berlese, forest litter, male, 25.6.1976, leg. S. Peck (FMNH); Brazil:
Mato Grosso, Campo Verde, farm Santa Luzia (55209'W, $15^{\circ} 433^{\prime}$ S), agric. field, male, 7.4.2014, leg. K. Peña Peña (UIC); Santa Carmen, farm Dona Dozolina $\left(55^{\circ} 113^{\prime} \mathrm{W}\right.$, $\left.11^{\circ} 597^{\prime} S\right)$, agric. field, 1 male, 3 females, 2.5.2014, leg. K. Peña Peña (UIC); same region, farm Såo Vincente $\left(55^{\circ} 215^{\prime} \mathrm{W}, 12^{\circ} 037^{\prime} \mathrm{S}\right), 1$ male, 3 females, 4.5.2014, leg. K. Peña Peña (UIC); 1 female, Rio de Janeiro, leg. Squires, Sharp coll. \#1905-313 (BMNH); Amazonas, 15 km SW Manaus, Ilha Marchanteria $\left(59^{\circ} 58^{\prime} \mathrm{W}, 3^{\circ} 15^{\prime} \mathrm{S}\right)$, tree emerg. trap, \#50D, male, 18.3.1982, leg. J. Adis (UIC); same location, but floating meadow, male, 29.4.1981, leg. J. Adis (UIC); same location, but Várzea, female, 20.1.1982, leg. J. Adis (UIC); Santa Catarina, Nova Teutonia, female, 12.1953, leg. F. Plaumann (FMNH); Santa Rita, female, 8.1850, leg. Sahlberg (FMNH); Paraguay: 3 females, without further data (SDEI); Argentina: JuJuy Prov., Termas del Reyes, 2 females, 27.12.1971, leg. L. Herman (AMNH); Buenos Aires, female, 190?, leg. C. Bruch $(\mathrm{FMNH})$.

Diagnosis: $D$. parvulus can be clearly identified by the specific paramere that is largely widened at apex and widely, but not deeply emarginate. Moreover, the colouration of the elytra with the anterior half mostly darkened
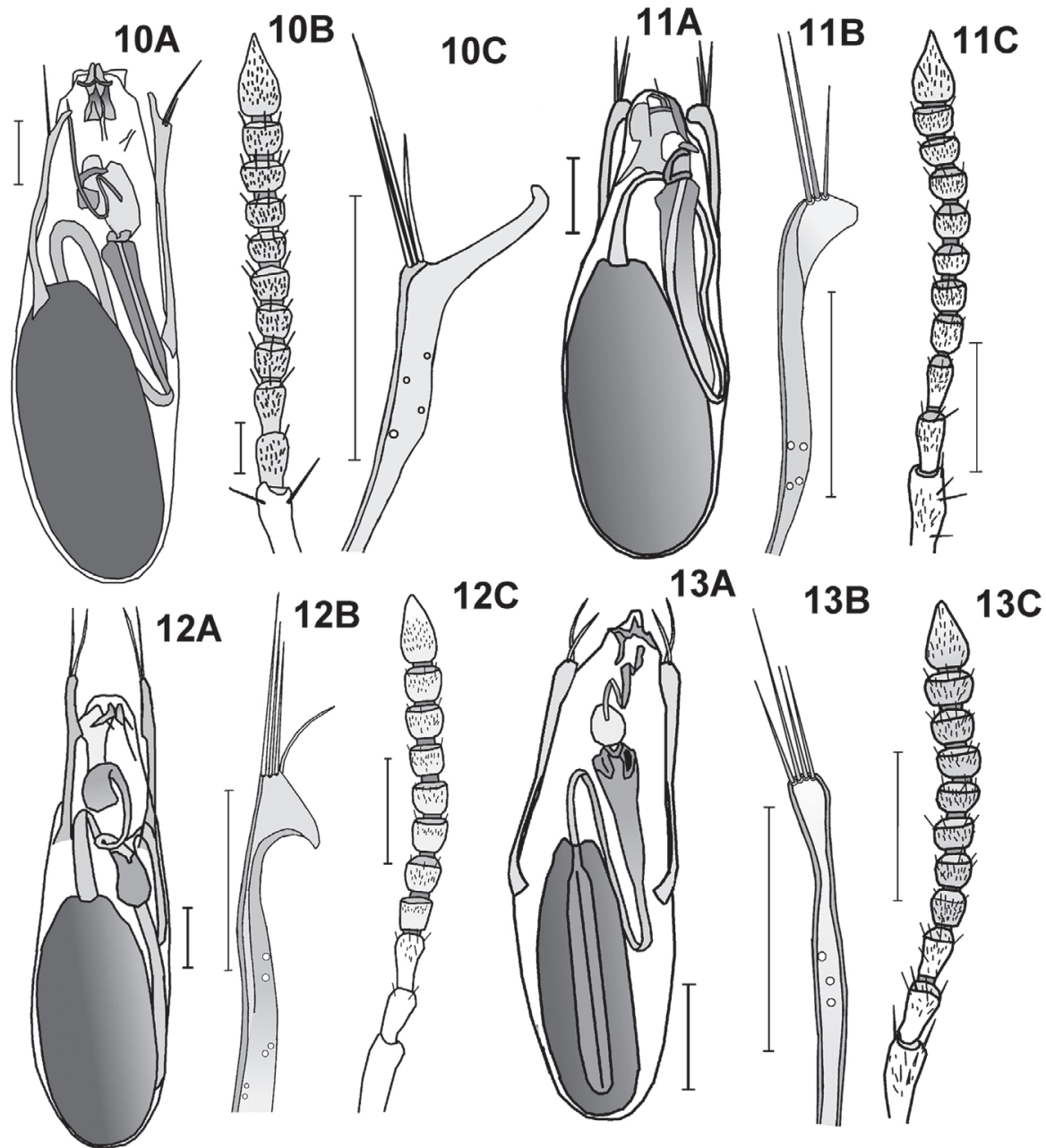

Figs 10-13: Diochus inornatus-group: of D. vicinus (10), D. antennalis (11), D. novus (12), D. tricolor (13); aedeagus (A), paramere (B) and antenna (C); scale bar: A, B: $0.1 \mathrm{~mm}$, C: $0.2 \mathrm{~mm}$. 
seems to be a character that can be used to distinguish it from the related species D. nanus, D. perplexus and D. apicipennis with mostly unicoloured elytra.

Description: Length: $3.1-3.2 \mathrm{~mm}$. Colouration: yellow; abdominal segments III-VI slightly darker, light brown; anterior half of elytra black; black area prolonged on disc to two third of elytral length; legs and antennae yellow with medial antennomeres darker.

Head: $0.41 \mathrm{~mm}$ long, $0.34 \mathrm{~mm}$ wide; eyes slightly prominent; temples 1.5 times as long as eyes; $\mathrm{EL}: \mathrm{HL}=0.28$; temples slightly divergent posteriad; $\mathrm{PW}: \mathrm{EW}=1.12$; posterior angles widely rounded to straight posterior margin; neck one third as wide as head; setiferous punctation coarse and sparse; moderately wide midline impunctate; row of five to six punctures adjacent to midline; interstices between punctures shorter on interocular area than on posterior vertex; on interocular area, interstices between punctures as wide as diameter of punctures; on posterior vertex, interstices twice or three times as wide as diameter of punctures; microsculpture weak; transverse netlike meshes; surface slightly shiny.

Antennae slightly longer than head; first antennomere one fourth longer than second; second and third conical; approximately one third longer than wide; fourth to tenth antennomere wider than long; fourth only shortly wider than long; seventh to ninth antennomere twice as wide as long; tenth slightly longer; all antennomeres pubescent and with few longer setae.

Pronotum: $0.49 \mathrm{~mm}$ long, $0.43 \mathrm{~mm}$ wide; widest shortly behind middle; distinctly stronger narrowed to anterior margin than to posterior margin; in dorsal aspect, fine lateral margin visible in posterior half; anterior angles more widely rounded than posterior angles; setiferous punctures extremely sparse; row of four pairs of punctures along impunctate midline; interstice of anterior pair twice as wide as interstice between posterior pairs of punctures; few setiferous punctures laterad; microsculpture similar as on head; surface polished.

Elytra: $0.48 \mathrm{~mm}$ long, $0.58 \mathrm{~mm}$ wide; sides divergent to posterior margin; shoulders distinct, but smoothly rounded; posterior margin emarginate in concave curve; setiferous punctures in four longitudinal rows; row along suture with approximately seven punctures; surface with weak coriaceous ground sculpture; less shiny than pronotum.

Abdomen with densely pubescent tergites; pubescence on apical tergites denser than on distal tergites.

Aedeagus broad; seminal vesical of endophallus 0.6 times as long as central lobe; basal inner duct with looped; ending in sclotised forceps; paramere

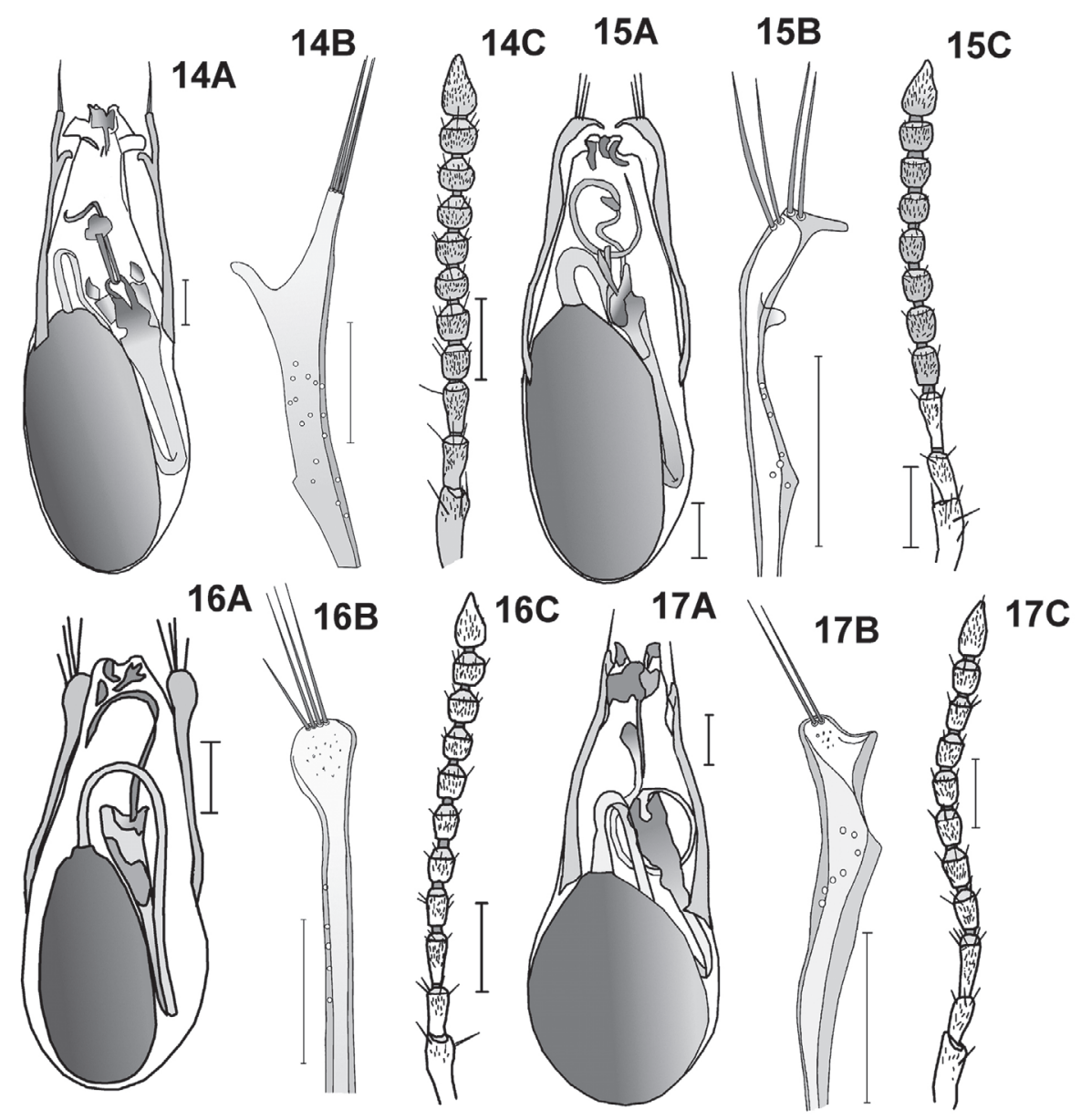

Figs 14-17: Diochus inornatus-group: of D. schuelkei (14), D. hermani (15), D. amazonenis (16), D. hibbsi (17); aedeagus (A), antenna (B) and paramere (C); scale bar: A, B: $0.1 \mathrm{~mm}, \mathrm{C}: 0.2 \mathrm{~mm}$. 
extremely widened at apex; slightly shorter than central lobe; apical margin with two short concave emarginations; outer angle prolonged to short acute tooth; inner angle broad and with two setae; third seta on triangular prominence between two emarginations; few sensillae in basal shaft.

Spermatheca $0.18 \mathrm{~mm}$ long, $0.15 \mathrm{~mm}$ wide; bursa copulatrix in lateral position to coiled approximately circular duct; duct few irregular coils.

\section{Diochus perplexus CAMERON, 1922}

Figs 34A-C, 40G, 45B

Diochus perplexus CAMERon, 1922: 116

Type material examined: Syntypes: Grenada: Gay East (Leeward side) W.I., female, leg. H.H. Smith, \#248; St. George's (Leeward side) W.I., female, leg. H.H. Smith, \#166.

Further material examined: Barbados: Turner Hall Wds., palm litter, rotted palm leaves, dung trap, 1 male, 1 female, 21.2.1979, leg. S. Peck (FMNH); Cuba: Havanna, 2 males, 2 females, leg. A. Bierig (NMW);
Grenada: Chantilly East, (Windward side), leg. H.H. Smith (IRSNB); without further data, 3 females, leg. Thaxter (FMNH); Guadeloupe: Buillante, Bois Malher, bridge ov. R. Margurite $\left(61^{\circ} 45.13^{\prime} \mathrm{W}\right.$, $\left.16^{\circ} 10.22^{\prime} \mathrm{N}\right)$, leaf litter, $50 \mathrm{~m}$ elevation, 2 males, 11.5.2015, leg. J.-M. Lemaire (UIC); without further data, 3 females, leg. Plason (FMNH); Dominican Republic: Prov. Duarte, $7.5 \mathrm{mi}$ NE San Francisco de Macoris, Loma de Quita Espucia, 800 ft elev., litter near stream, 3 males, 3 females, 24.7.1991, leg. L. Herman, \#2599 (4 AMNH, 2 UIC); Prov. La Vega, $7.4 \mathrm{~km} \mathrm{~W}$ Bonao, road to Constanza, leaf litter near stream, 2 males, 7 females 5.8.1991, leg. L. Herman, \#2597 (7 AMNH, 2 UIC); Jarraboca, nr. Hotel Cabana Pinar Dorado, leaf litter under Mango tree, $1800 \mathrm{ft}$. elev., 2 males, 4 females, 31.5.1983, leg. G. Mazurek \& D. Matusik (FMNH); Barrahona, nr. ocean, coconut husks, female, 28.5.1983, leg. G. Mazurek \& D. Matusik (FMNH); Puerto Rico: San Juan, without more details $(\mathrm{AMNH}) ;$ British Virgin Islands: Guana $\left(18^{\circ} 28^{\prime} \mathrm{N}\right.$, $\left.64^{\circ} 33^{\prime} \mathrm{W}\right)$, Tamarind litter \& grass leaf cuttings debris, 1 male, 4 females, 15.-20.10. 1995, leg. L. Herman (4 AMNH, 1 UIC)); Trinidad: Balandra Bay, 2 males, 3 females, 4. \& 5.1922, leg. F. Psota (FMNH); without further data, 1 male, 3 females, leg. Thaxter $(3 \mathrm{FMNH}$,
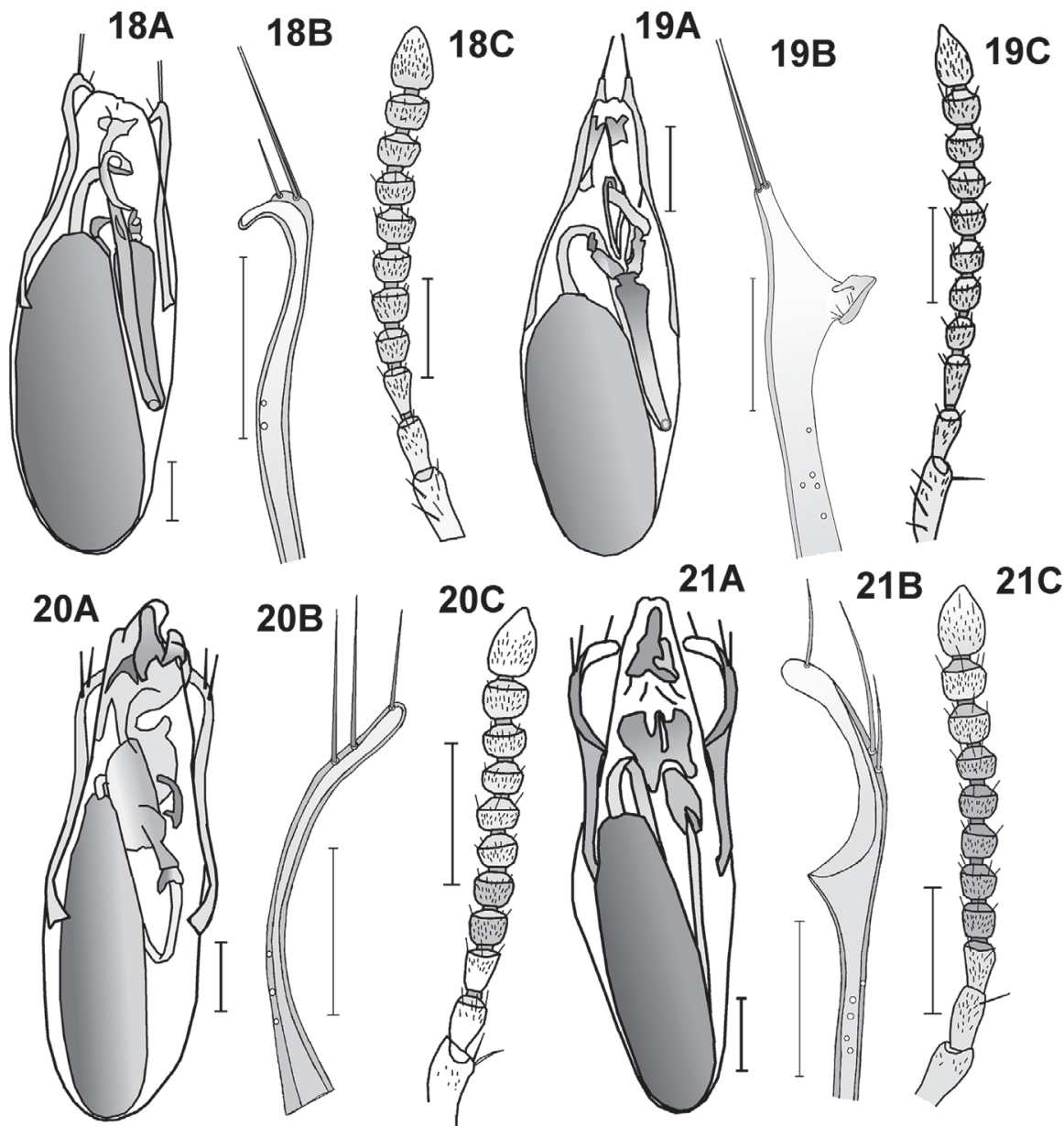

Figs 18-21: Diochus inornatus-group: D. plaumanni (18), D. newtoni (19) and Diochus maculicollis-group: D. brooksi (20), D. ecuadoriensis (21); aedeagus (A), paramere (B) and antenna (C); scale bar: A, B: $0.1 \mathrm{~mm}, \mathrm{C}: 0.2 \mathrm{~mm}$. 
1 AMNH); without further data, 2 males, \#2849/50 (FMNH); Guatemala: Zacapa, $7.6 \mathrm{~km} \mathrm{~W} \mathrm{Teculután,}$ $330 \mathrm{~m}$ elevation, along stream in leaf packs, 4 males, 2 females, 2.6.1993, leg. J. Ashe, R. Brooks, \#93-108 (4 KNHM, 2 UIC); Honduras: Atlantida Lancetilla Bot. Grd., Tela $\left(15^{\circ} 46^{\prime} \mathrm{N}, 87^{\circ} 27^{\prime} \mathrm{W}\right), 10 \mathrm{~m}$ elev., male, 23.6.1994, leg. J. Ashe, R. Brooks \#198 (KNHM); Nicaragua: Dept. San Ramon $\left(12^{\circ} 53.50^{\prime} \mathrm{N}, 85^{\circ} 50.22^{\prime} \mathrm{W}\right)$, $450 \mathrm{~m}$ elev., stream litter, 114 specimens, 22.12.2002, leg. L. Herman (106 AMNH, 8 UIC); Rio San Juan Dept., $60 \mathrm{~km}$ SE San Carlos, Refugio Bartola $\left(10^{\circ} 58.4^{\prime} \mathrm{N}\right.$, $\left.84^{\circ} 20.3^{\prime} \mathrm{W}\right), 100 \mathrm{~m}$ elev., pyrethrum fogging fungusy log, female, 26.5.2002, leg. R. Brooks, Z. Falin, S. Chatzimanolis \#NIC1BFC02 074 (KNHM); Costa Rica: Heredia, La Selva, Biol. Station, nr. Puerto Viejo de Sarapiqui, 2 females, 18.2.1985, leg. L. Herman \#2113 (AMNH); San José, 4 km E San Mateo, $500 \mathrm{ft}$ elev., litter, 1 male, 2 females, 10.2.1985 and 27 specimens 16.2.1985, leg. L. Herman \#2103, \#2106 (27 AMNH, 3 UIC); Guancaste Prov. Nicoya Peninsula, PN Diria, Area de Conservacion Tempisque $\left(85^{\circ} 35.44^{\prime} \mathrm{W}, 10^{\circ} 09.43^{\prime} \mathrm{N}\right)$, $135 \mathrm{~m}$ elevation, river bank and old car track, 9 males, 1 female, 15.12.2013, leg. M. Schülke (7 MSC, 3 UIC); NE Boca Tapada, Laguna de Lagarto Lodge $\left(84^{\circ} 10.51^{\prime} \mathrm{W}\right.$, $\left.10^{\circ} 41.10^{\prime} \mathrm{N}\right), 46 \mathrm{~m}$ elevation, compost heap, sifted, male,
11.12.2012, leg. M. Schülke (UIC); PN Rincón de la Vieja, circle path $\left(85^{\circ} 20.48^{\prime} \mathrm{W}, 10^{\circ} 46.31^{\prime} \mathrm{N}\right)$, litter near creek, sifted, male, 5.12.2012, leg. M. Schülke (UIC); Guanacaste, Lomas Babudal Biological Reserve $\left(85^{\circ} 2215^{\prime} \mathrm{W}, 10^{\circ} 3022^{\prime} \mathrm{N}\right), 17 \mathrm{~m}$ elevation, fogging fungus covered log, 1 male, 2 females, 15.7.2000 leg. J. Ashe, R. Books, Z. Falin, \#CR1ABF00 136 (KNHM); Volcan Rincon de la Vieja, S. slope, leaf litter, $2800 \mathrm{ft}$. elv., 2 females, 29.6.1993, leg. J. Doyen \& M. Caterino (FMNH); Heredia, $3 \mathrm{~km}$ S Puerto Viejo, OTS La Selva, $100 \mathrm{~m}$ elevation, 7 females Oct.1992, leg. P. Hanson (6 KNHM, 1 UIC); Cartago, P.N. Tapanti $\left(83^{\circ} 47.5^{\prime} \mathrm{W}\right.$, $\left.9^{\circ} 45.41^{\prime} \mathrm{N}\right), 1150 \mathrm{~m}$ elevation, fogging fungus covered log, 2 males, 18.7.2000, J. Ashe, R. Brooks, Z. Falin, \#CR1ABF00 166 (KNHM); Puntarenas, Osa Penisnula, Fundación Neotrop., $10 \mathrm{~km} \mathrm{~W}$ Rincon $\left(83^{\circ} 25^{\prime} \mathrm{W}\right.$, $\left.8^{\circ} 45.3^{\prime} \mathrm{N}\right), 20 \mathrm{~m}$ elevation, berlese forest litter, 1 female, 23.6.1997, 1 female $\left(83^{\circ} 31.3^{\prime} \mathrm{W}, 8^{\circ} 42.3^{\prime} \mathrm{N}\right), 22.6 .1997$, 1 female, 23.6.2001, leg. R. Anderson, CR1A97 033C, CR1A97 027G, CR1A01 118 (KNHM); Puntarenas, Rincon, 17 km NE, Cerro Helado, $250 \mathrm{~m}$ elevation, collected by flight intercept trap, 1 male, 21.-25.6.1997, leg. S. \& J. Peck, \#CR1P97 026 (KNHM); Puntarenas Prov., W Rincon, nr. Fundacion Neotropica, 4 males, 10 females, 25.3.1991, leg. L. Herman (12 AMNH,
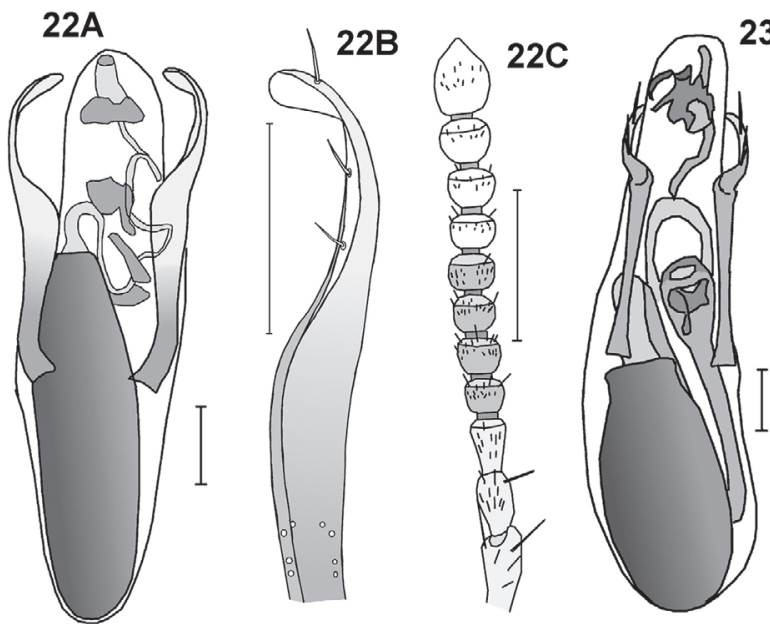

$23 \mathrm{~A}$
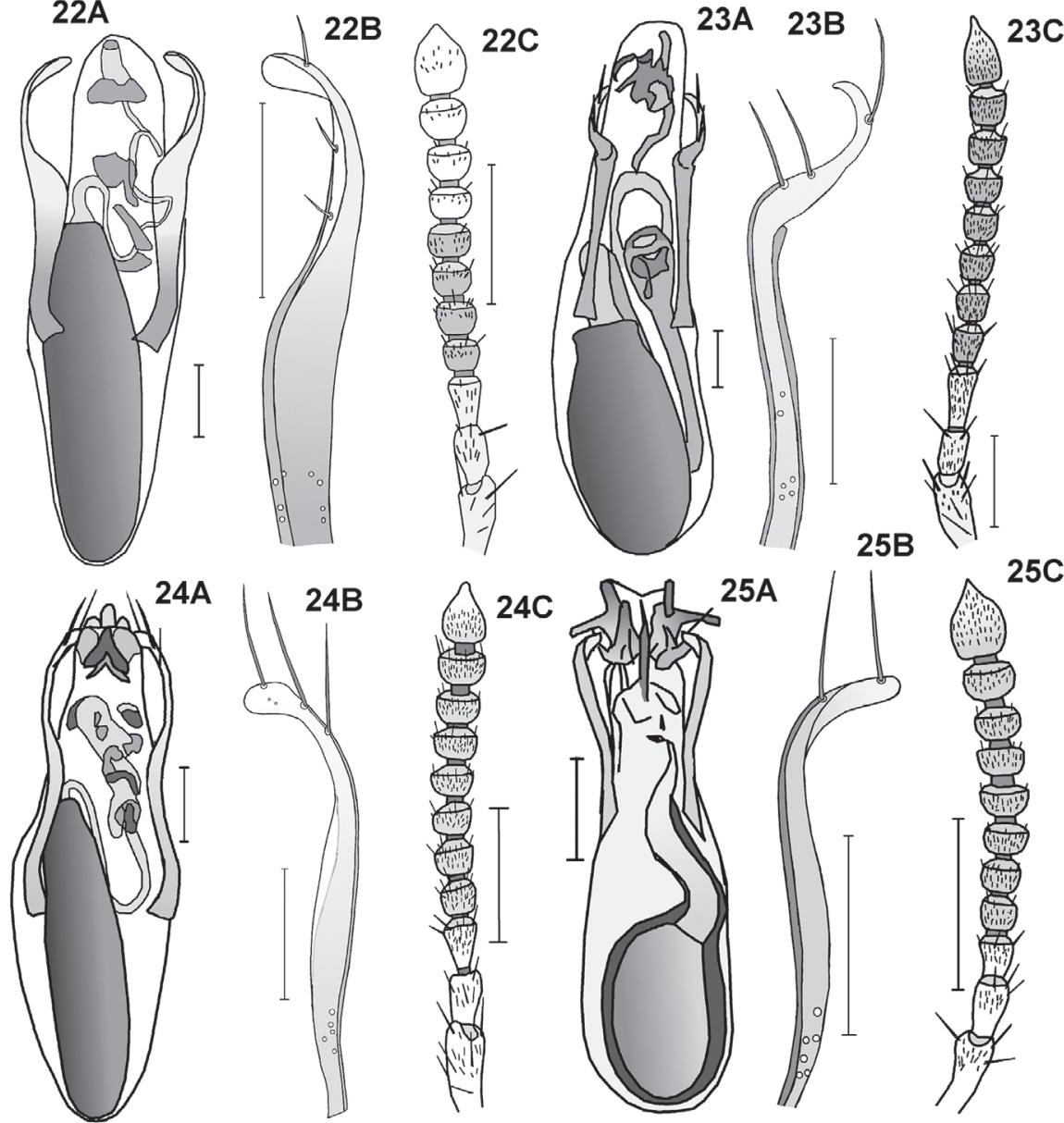

Figs 22-25: Diochus maculicollis group: of D. maculicollis (22), D. peruvianus (23), D. mexicanus (24), D. pumilio (25); aedeagus (A), paramere (B) and antenna (C); scale bar: A, B: $0.1 \mathrm{~mm}, \mathrm{C}: 0.2 \mathrm{~mm}$. 
2 UIC); Puntarenas, Las Cruces Botanical Garden near San Vito, 3500 ft elev., female, 2.1985, leg. L. Herman, \#2133 (AMNH); Puntarenas, OSA Peninsula, $5 \mathrm{~km} \mathrm{~W}$ Rincon de Osa $\left(83^{\circ} 31^{\prime} \mathrm{W}, 8^{\circ} 42^{\prime} \mathrm{N}\right), 50 \mathrm{~m}$ elev., Berlese, under bark lean in stream bed, forest covered, or mixed floor litter in shade streambed, primary forest, 1 male, 2 females, 24.-30.3.1973, leg. J. Wagner \& J. Kethley (FMNH); OTS St., Finca Las Cruces, San Vito $\left(82^{\circ} 58^{\prime} \mathrm{W}\right.$, $\left.8^{\circ} 46^{\prime}\right), 4000 \mathrm{ft}$. elev., Berlese, under bark \& rot, log galleries, or epiphytic humus, old saw mill site, 2 males, 1 female, 19.3.1973, leg. J. Wagner \& J. Kethley (FMNH); Guanacaste, Cañas, Finca la Pacifica, NW Cañas, spring next to Rio Corobici $\left(85^{\circ} 8^{\prime} \mathrm{W}, 10^{\circ} 27^{\prime} \mathrm{N}\right)$, moss, grass roots, leaves, $80 \mathrm{~m}$ elev., 3 females, 7.4.1973, leg. J. Wagner \& J. Kethley (FMNH); Comelco, Palo Verde, OTS $9 \mathrm{~km} \mathrm{~W}$ Bagaces $\left(85^{\circ} 18^{\prime} \mathrm{W}, 10^{\circ} 32^{\prime} \mathrm{N}\right), 40 \mathrm{~m}$ elev., Berlese, leaf mold + sticks on coarse sand in shade below falls, 4 males, 10 females, 9.4.1973, leg. J. Wagner \& J. Kethley (12 FMNH, 2 UIC); Canas, Miravalles Volcano $\left(85^{\circ} 7^{\prime} \mathrm{W}, 10^{\circ} 42^{\prime} \mathrm{N}\right)$, Berlese, bark mixed log mold, 1 male, 2 females, 8.4.1973, leg. J. Wagner \& J. Kethley (FMNH); Limon, Reventazon, Hamburg Farm, sifted, swamp litter, 1 male, 4 females, 7.8.1933, leg. F. Nevermann (FMNH); Heredia, Puerto Viejo de Sarapiqui, OTS La Selva Field Sta., Rio Puerto Viejo $\left(83^{\circ} 59^{\prime} \mathrm{W}, 10^{\circ} 26^{\prime} \mathrm{N}\right)$, Berlese, bromeliad root fibres, cups, axils, female, 5.-11.3.1973, leg. J. Wagner \& J. Kethley (FMNH); San Mateo, 500 m elev., 2 females, 28.2.1939, leg. A. Bierig (FMNH); San Pablo de Tbrs., $400 \mathrm{~m}$ elev. 4 females, 14.-15.4.1939, leg. A. Bierig (FMNH); Desmonte, 500 m elev., 1 male, 1 female, 28.2.-1.3.1939, leg. A. Bierig (FMNH); Caldera, 3 females, 13.11.1943, leg. A. Bierig (FMNH); Esparta, 2 males, 4 females, 24.1.1943, leg. A. Bierig (FMNH); Atenas, 2 females, 18.4.1940, leg. A. Bierig (FMNH); Chitaria, Alto del Carrizal, female, 9.-13.4.1941, leg. A. Bierig (FMNH); Sardinal, female, 23.2.1941, leg. A. Bierig (FMNH); Panama: Colon, Parque Nac. Soberania, Pipeline Rd. $\left(79^{\circ} 45^{\prime} \mathrm{W}, 9^{\circ} 07^{\prime} \mathrm{N}\right)$, tree leaf litter, 1 male, 26.5.1995; leg. J.A. Ashe, \#065 (KNHM); Cerro Campana, near Capira $\left(79^{\circ} 57^{\prime} \mathrm{W}, 8^{\circ} 44^{\prime} \mathrm{N}\right), 900 \mathrm{~m}$ elevation, male, 5.6.1995, leg. R. Anderson, \#PAN2A95 02B (KNHM); Chiriqui, $20 \mathrm{~km}$ N Gualaca, Finca La Suiza $\left(8^{\circ} 39.0^{\prime} \mathrm{N}, 82^{\circ} 12.0^{\prime} \mathrm{W}\right)$, $1250 \mathrm{~m}$ elevation, berlese forest litter, female, 10.6.1995, leg. R. Anderson \#PAN2A95 15D (KNHM); same location and date, but $1200 \mathrm{~m}$ elevation, oak forest litter 2 females, \#PAN2A95 16E/16D (KNHM); same location, but fungusy log, $1350 \mathrm{~m}$ elev., female, 22.5.1995, leg. J. Ashe \#036 (KNHM); Chiriqui Prov. near Finca Cordillera Mach de Monte $\left(8^{\circ} 41.07^{\prime} \mathrm{N}, 82^{\circ} 36.23^{\prime} \mathrm{W}\right)$,
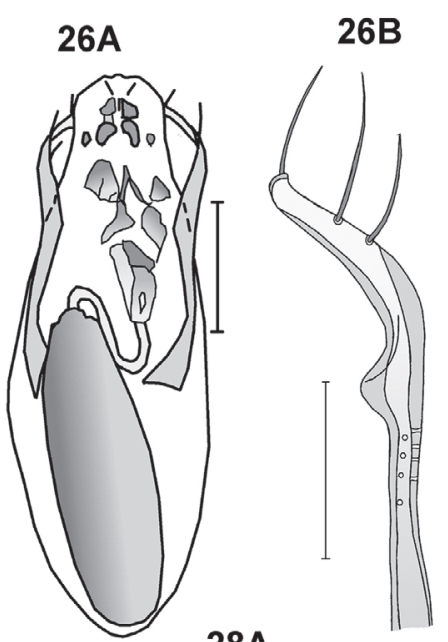

26C
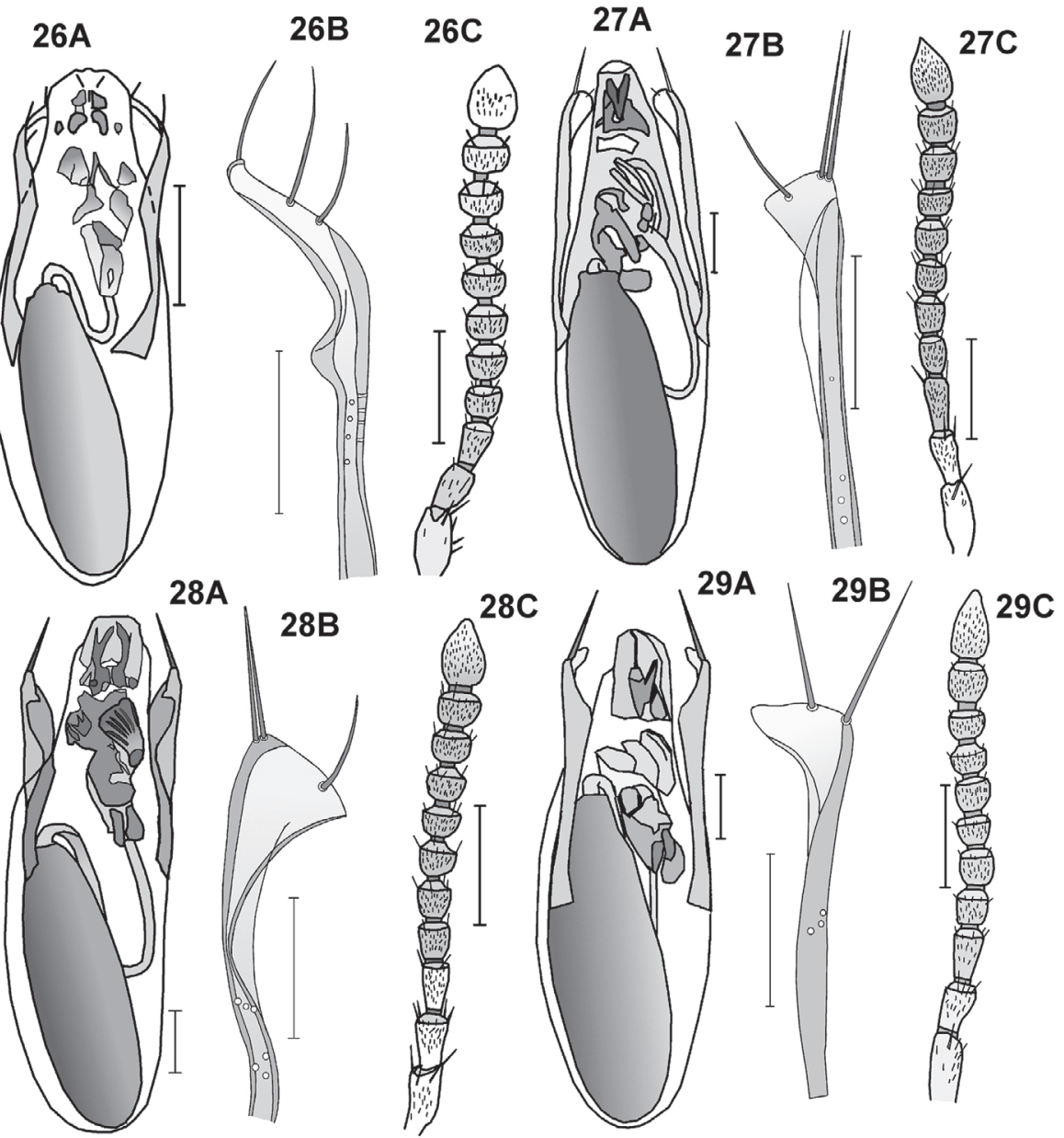

Figs 26-29: Diochus maculicollis group: D. panamensis (26), and Diochus schaumii-group D. schaumii (27), D. angustiformis (28), D. argentinae (29); aedeagus (A), paramere (B) and antenna (C); scale bar: A, B: $0.1 \mathrm{~mm}$, C: $0.2 \mathrm{~mm}$. 
$990 \mathrm{~m}$ elev., litter near stream, 3 males, 4 females, 21.5.2001, leg. L. Herman \& W. Opitz (5 AMNH, 2 UIC); Dolega, $550 \mathrm{~m}$ elev., litter near stream, female, 22.5.2001, leg. L. Herman \& W. Opitz (AMNH); Boquete, coffee tree litter, female, 2.10.1975, leg. D.S. Chandler (FMNH); Cuernavaca, camp W of Laguna on Cerro Arriera, fibrous core, dead century plant, $850 \mathrm{~m}$ elev., male, 25.1.1981, leg. W. Suter (FMNH); 2 km S Cuernavaca camp, Rincon Vly., $750 \mathrm{~m}$ elev., damp litter on semi cleared hillside, between rock \& log, female, 16.1.1981, leg. W. Suter (FMNH); Escopeta $(\mathrm{N})$, along Rio Escopeta, $860 \mathrm{~m}$ elev., litter under banana, 1 male, 1 female, 9.1.1981, leg. W. Suter (FMNH); Cerro Colorado, 1290 m elev., grassy ecotonal debris, female, 10.1.1981, leg. W. Suter (FMNH); same location, but under bamboo, $1220 \mathrm{~m}$ elev. female, 7.1 .1981 , leg. W. Suter (FMNH); Coclé, $7.2 \mathrm{~km} \mathrm{NE} \mathrm{El}$ Copé $\left(8^{\circ} 37^{\prime} \mathrm{N}, 80^{\circ} 35^{\prime} \mathrm{W}\right), 730 \mathrm{~m}$ elevation, flight intercept trap, female, 20.5.-7.6.1995, leg. J. Ashe, R. Brooks (KNHM); Qda. Laguna, nr. Rio San Felix, 725 m elev., litter on sand. pocket S. bank, 5 males, 9 females, 19.1.1981, leg. W. Suter (12 FMNH, 2 UIC); Darién, Cana Biological Station $\left(77^{\circ} 41.6^{\prime} \mathrm{W}, 7^{\circ} 45.18^{\prime} \mathrm{N}\right), 530 \mathrm{~m}$ elevation, collected by flight intercept trap, 2 females, 7.-9.Jun.1996, leg. J. Ashe \& R. Brooks, \#PAN1AB96 113 (KNHM); Panama Prov. 1 km NE San Carlos $\left(8^{\circ} 29.30^{\prime} \mathrm{N}\right.$, $\left.79^{\circ} 57.30^{\prime} \mathrm{W}\right), 60 \mathrm{~m}$ elev., litter near stream, 4 males,
8 females, 15.5.2001, leg. L. Herman \& W. Opitz (10 AMNH, 2 UIC); Campana $\left(8^{\circ} 42.52^{\prime} \mathrm{N}, 79^{\circ} 54.02^{\prime} \mathrm{W}\right)$, $190 \mathrm{~m}$ elev., litter near stream, 1 male, 2 females, 24.1.2001, leg. L. Herman \& W. Opitz (AMNH); Campana $\left(8^{\circ} 42.54^{\prime} \mathrm{N}, 79^{\circ} 54.02^{\prime} \mathrm{W}\right), 200 \mathrm{~m}$ elev., litter near stream, 12 females, 31.12.2001, leg. L. Herman (AMNH); Canal Zone, Albrook Forest Site, $100 \mathrm{ft}$. elev., on ground, 2 females, 20.1.1968, leg. R. Hutton (AMNH); same location, but collected with ground black light trap, 2 males, 3 female, 30.-31.1.1968, and 28.-29.3.1968, leg. R.S. Hutton (AMNH); Barro Colorado Is., female, 11.1952-3.1953, leg. J. Zatek (AMNH); road to Cerro Campana $\left(8^{\circ} 41^{\prime} \mathrm{N}, 82^{\circ} 55.12^{\prime} \mathrm{W}\right), 730 \mathrm{~m}$ elev., litter near stream, 1 male, 4 females, 22.12.2001, leg. L. Herman (AMNH); road to Cerro Campana $\left(8^{\circ} 41.03^{\prime} \mathrm{N}, 79^{\circ} 55.10^{\prime} \mathrm{W}\right), 740 \mathrm{~m}$ elev., litter near stream, 4 males, 5 females, 2.1.2002, leg. L. Herman (7 AMNH, 2 UIC); same data, but $\left(8^{\circ} 41.20^{\prime} \mathrm{N}, 79^{\circ} 54.50^{\prime} \mathrm{W}\right), 645 \mathrm{~m}$ elev., litter nr. seep, and $280 \mathrm{~m}$ elev., litter near stream, 13 males, 38 females, 1.1.2002, leg. L. Herman (45 AMNH, 6 UIC); Cerro Campana, wet debris, of small forest stream, $3200 \mathrm{ft}$. elev., 1 male, 4 females, 23.2.1976, leg. A. Newton (FMNH); same location, Berlese, cloud forest leaf litter, 14./23.2.1976, leg. A. Newton (FMNH); Cerro Campana, $2400 \mathrm{ft}$. elev., leaves in stream-bed, sifted, female, 17.2.1959, H.S. Dybas (FMNH); Veraguas Prov., Paris $\left(80^{\circ} 53.2^{\prime} \mathrm{W}\right.$,
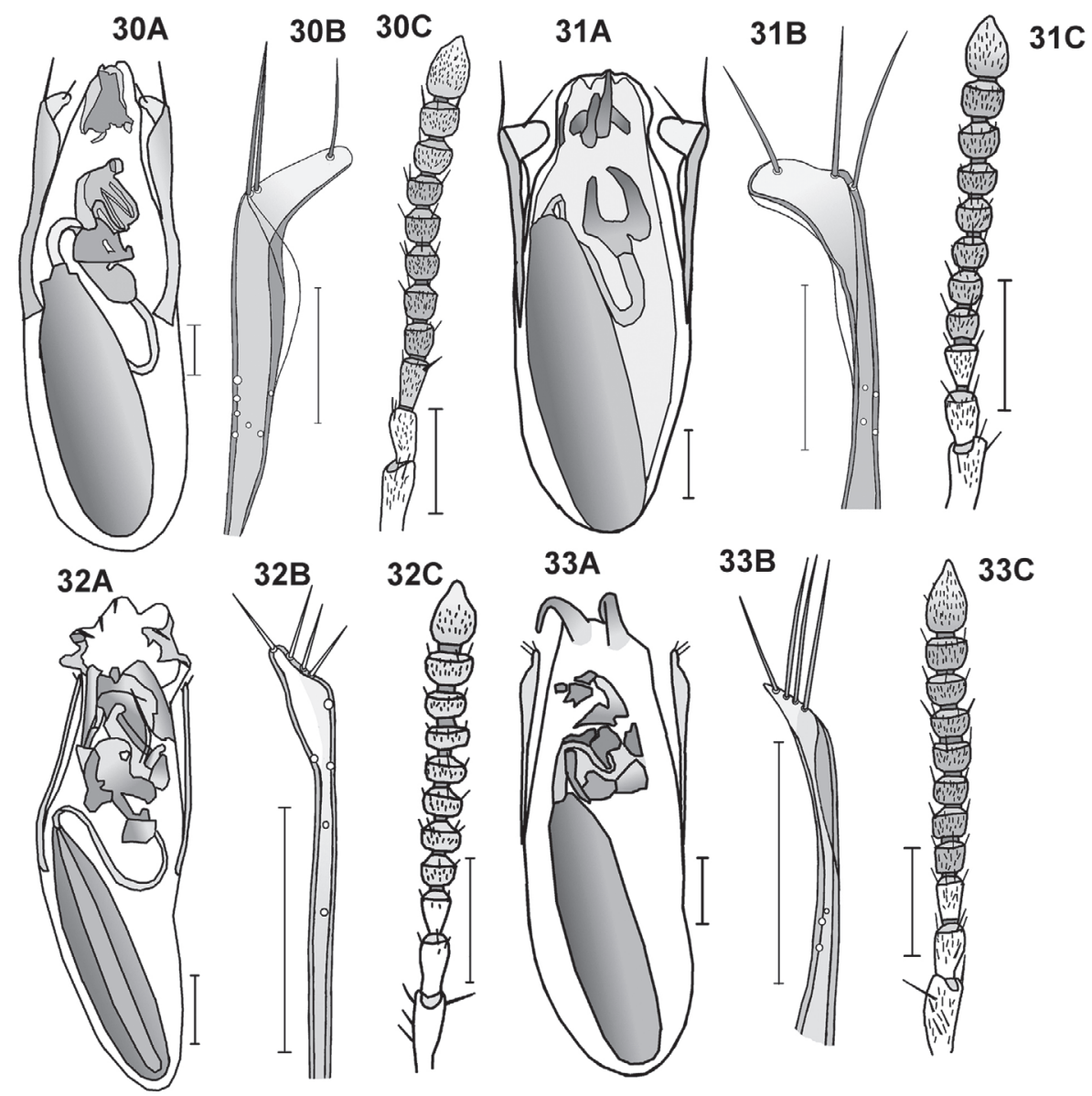

Figs 30-33: Diochus schaumii-group: D. brunneus (30), D. curtipennis (31), and Diochus verhaaghi-group: D. verhaaghi (32), D. santacatarinae (33); aedeagus (A), paramere (B) and antenna (C); scale bar: A, B: $0.1 \mathrm{~mm}$, C: $0.2 \mathrm{~mm}$. 
$\left.8^{\circ} 11.2^{\prime} \mathrm{N}\right)$, coastal swamp, sifted, 1 male, 6 females, 1.8.2014, leg. Struyve (5 TSC, 2 UIC); Cerro Azul, wet debris small forest stream, $200 \mathrm{ft}$. elev., 10 males, 8 females, 21.2.1976, leg. A. Newton (17 FMNH, 1 UIC); Canal Zone, Barro Colorado Is., litter under old tree and vine fall, 4 males, 3 females, 27.2.1976, leg. A. Newton (FMNH); same location, but litter under fungusy logs, male, 4.2.1976, leg. A. Newton (FMNH); same location, litter under rotting log, female, 13.2.1976, leg. A. Newton (FMNH); same location, but litter under rotting logs, female, 6.2.1976, leg. A. Newton (FMNH); same location, but Fairchild Trail, bark \& under bark debris, female, 28.1.1959, leg. H.S. Dybas (FMNH); same location, but dead palm debris, female, 28.1.1959, leg. H.S. Dybas (FMNH); nr. Arraijan, leaves in streambed \& flight, late afternoon, 1 male, 3 females, 11.2.1959, leg. H.S. Dybas (FMNH); 12 mi. NW Gamboa, Rio Agua Salud, flood debris along rivers, male, 19.2.1976, leg. A. Newton (FMNH); Balboa, Cerro Ancon, leaf litter, sifted, female, 24.10.1975, leg. D.S. Chandler (FMNH); Panama Prov., Las Cumbres, forest litter, sifted or Berlese, old or young forest, 3 males, 2 females, 24.10.1975, leg. D.S. Chandler (FMNH); Altos de Majé, under tree bark, sifted, 4 males, 4 females, 6/15.10.1975, leg. D.S. Chandler (FMNH); Conita (W), at river flood plain, palm buttress with stump, female, 3.1.1981, leg.
W. Suter (FMNH); El Liano (W), litter at log, female, 3.1.1981, leg. W. Suter (FMNH); Madden Lake, near dam, Berlese, damp pockets of leaves \& debris in streambed, 5 males, 6 females, 15.2.1959, leg. H.S. Dybas (10 FMNH, 1 UIC); same location, grass and leaves, sifted, female, 15.2.1959, leg. H.S. Dybas (FMNH); same location, but Atta rubbish heap, 2 females, 7.2.1959, leg. H.S. Dybas (FMNH); Bocas del Torro Prov., Almirante, Berlese, woodborer debris, in split of tree, 4 females, 22.3.1959, leg. H.S. Dybas (FMNH); same location, dam on Nigua creek, Berlese, center of decayed palm log, 23.3.1959, leg. H.S. Dybas (FMNH); Panama Prov. France Field, 1 male, 3 females, 6.1939, leg. A. Bierig (FMNH); Juan Diaz, 1 male, 1 female, 12.7.1930, leg. A. Bierig (FMNH); Pueblo Nuevo, female, 6.1930, leg. A. Bierig (FMNH); Almirante, (Edw. Maríu), female, 4.1943, leg. A. Bierig (FMNH); Venezuela: Sucre Prov., Puy Puy $\left(62^{\circ} 58.05^{\prime} \mathrm{W}, 10^{\circ} 42^{\prime} \mathrm{N}\right)$, forest, female, 31.3.1998, leg. C. Schmidt (UIC); Guarico Prov., Cantagallo $\left(67^{\circ} 25.44^{\prime} \mathrm{W}, 9^{\circ} 47.52^{\prime} \mathrm{N}\right)$, under stones, female, 13.3.1998, leg. C. Schmidt (UIC); Aragua, Rancho Grande, Biological Station, $28 \mathrm{~km} \mathrm{~N}, \mathrm{~km} 48\left(67^{\circ} 41^{\prime} \mathrm{W}\right.$, $\left.10^{\circ} 28^{\prime} \mathrm{N}\right), 120 \mathrm{~m}$ elevation, collected by flight intercept trap, 18 males, 2 females, 6.-18.7.1994, leg. T. Phillips, \#VEN 1P94 22 (16 KNHM, 4 UIC); same location and collecting method, but $\left(67^{\circ} 41^{\prime} \mathrm{W}, 10^{\circ} 21^{\prime} \mathrm{N}\right), 1100 \mathrm{~m}$

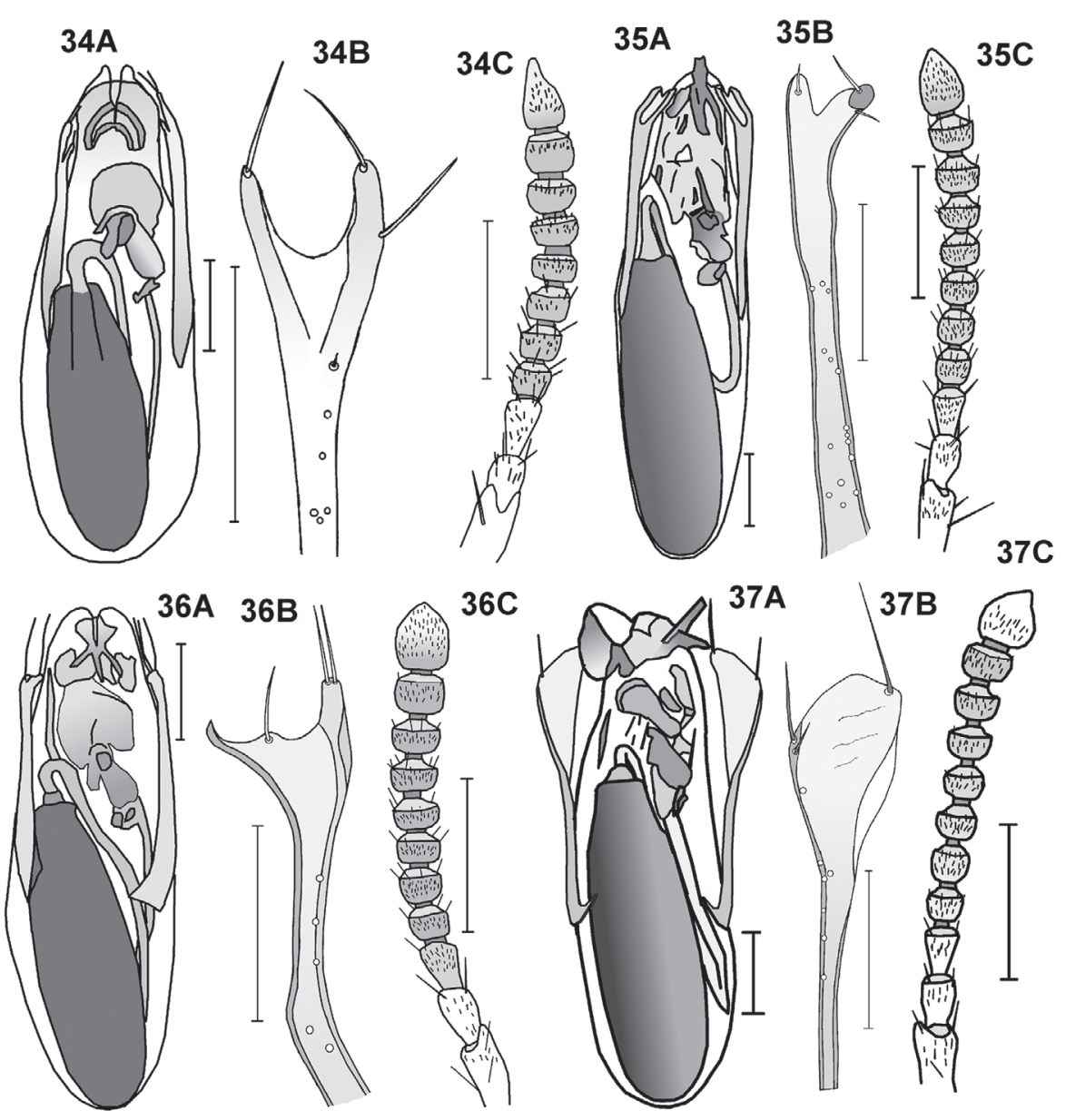

Figs 34-37: Diochus nanus-group, Diochus perplexus (34), D. nanus (35), D. parvulus (36), D. apicipennis (37); aedeagus (A), antenna (B) and paramere (C); scale bar: A, B: $0.1 \mathrm{~mm}$, C: $0.2 \mathrm{~mm}$. 
elevation, 2 females, 24.6.-6.7.1994, leg. T. Phillips, \#VEN1P94 021 (KNHM); same location and collecting method, but $16 \mathrm{~km} \mathrm{~N}, \mathrm{~km} 36\left(67^{\circ} 41^{\prime} \mathrm{W}, 10^{\circ} 24^{\prime} \mathrm{N}\right), 340 \mathrm{~m}$ elevation, 1 female, 4.-8.7.1994, leg. T. Phillips, \#VEN1P94 005 (KNHM); Aragua, Ocumare, 2.5 km NE $\left(63^{\circ} 41^{\prime} \mathrm{W}, 10^{\circ} 03^{\prime} \mathrm{N}\right), 80 \mathrm{~m}$ elevation, collected by flight intercept trap, 2 males, 6 females, 4.-18.7.1994, leg. T. Phillips, \#VEN1P94 020 (6 KNHM, 2 UIC); Bolivar, nr. Icabarú, $110 \mathrm{~km}$ SW Sta. Elena de Uairen, forest litter, $490 \mathrm{~m}$ elevation, female, 5.7 .1987 (KNHM); Trujillo Prov. 60.6 km NW Bocono, 1900 ft. elev., litter near stream, male, 31.3.1992, leg. L. Herman \#2654 (AMNH); Los Chorros, 2 females, 5.1922, leg. L.R. Reynolds (FMNH); Colombia: Magdalena, PNN Tayrona Cañaveral $\left(74^{\circ} 02^{\prime} \mathrm{W}, 11^{\circ} 20^{\prime} \mathrm{N}\right), 30 \mathrm{~m}$ elevation, Red, female, 25.4.2000-27.4.2000, leg. Samiento, \#M.3605 (KNHM); same location, but $\left(73^{\circ} 56^{\prime} \mathrm{W}\right.$, $\left.11^{\circ} 19^{\prime} \mathrm{N}\right), 200 \mathrm{~m}$ elevation, dry forest litter sample,
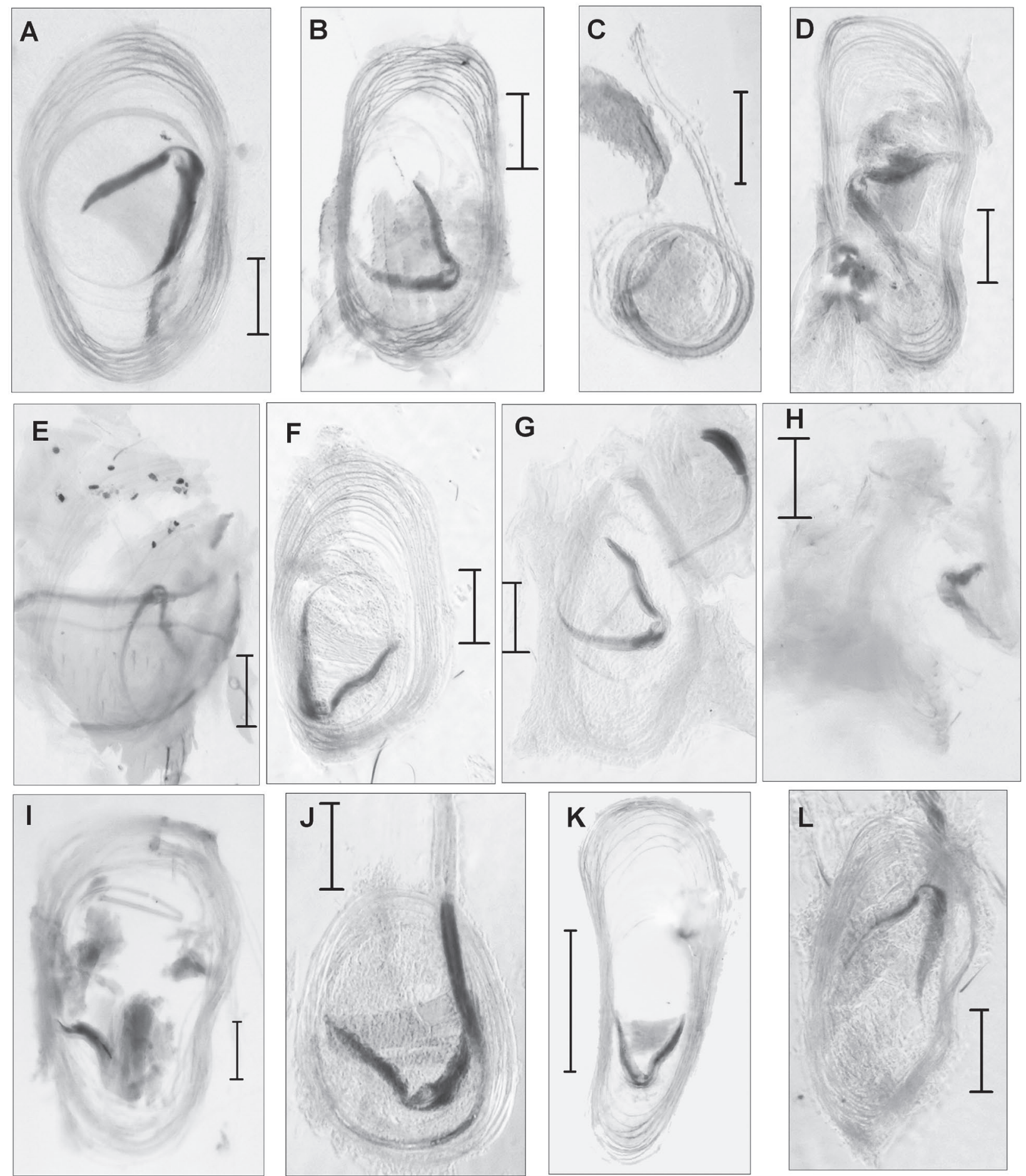

Fig. 38: Spermathecae of Diochus longicornis-group: D. longicornis (A), D.tarsalis (B), D. ashei (C), D. guianensis (D), D. unicolor (E); Diochus inornatus-group: D. inornatus (F), D. hanagarthi (G), D. antennalis (lateral aspect H), D. hermani (I), D. hibbsi (J), D. newtoni (K), D. novus (L); scale bar: $0.1 \mathrm{~mm}$. 
1 female, 1 male, 11.8.1985, leg. J. Longino, \#708 (1 KNHM, 1 UIC); same Prov., $4 \mathrm{~km} \mathrm{~N}$ San Pedro $\left(10^{\circ} 57^{\prime} \mathrm{N}, 74^{\circ} 03^{\prime} \mathrm{W}\right), 550 \mathrm{~m}$ elev., leaf litter, female, 14.8.1985, leg. J. Longino \#763-5 (KNHM); Guyana: Region 8, Iwokrama Forest, Kabocalli Field Stn. $\left(58^{\circ} 30.3^{\prime} \mathrm{W}, 4^{\circ} 17.4^{\prime} \mathrm{N}\right)$, grass slash, 1 male, 5.6.2001, leg. R. Books, Z. Falin, \#GUY1BF01 147 (KNHM); Magda- lena, Gaira, 8 km S Santa Marta, 8 males, 20 females, 16.3.1974, leg. L. \& N. Herman, \#1106-1107 (22 AMNH, 6 UIC); French Guiana: Barrage de Petit Saud (530.' W, $\left.5^{\circ} 03^{\prime} \mathrm{N}\right)$, car net, female, 15.11.2011, leg. T. Struyve (TSC); Caussade $\left(52^{\circ} 57^{\prime} \mathrm{W}, 5^{\circ} 10^{\prime} \mathrm{N}\right)$, car net, 9 females, 6.11.2011, 7.11.2011, leg. T. Struyve (7 TSC, 2 UIC); Ecuador: Pichincha, Maquipucuna For. Res., $50 \mathrm{~km} \mathrm{NW}$
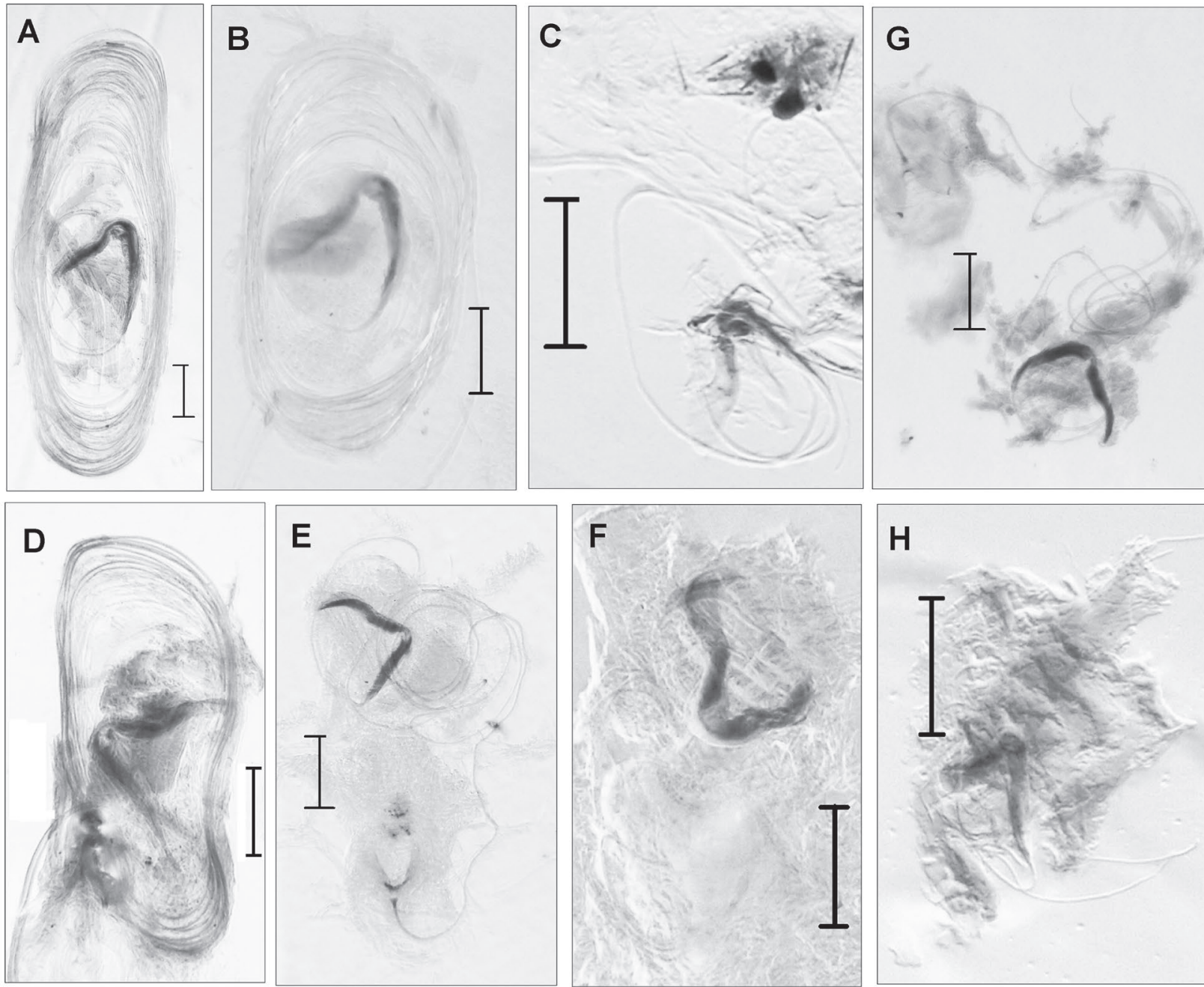

H

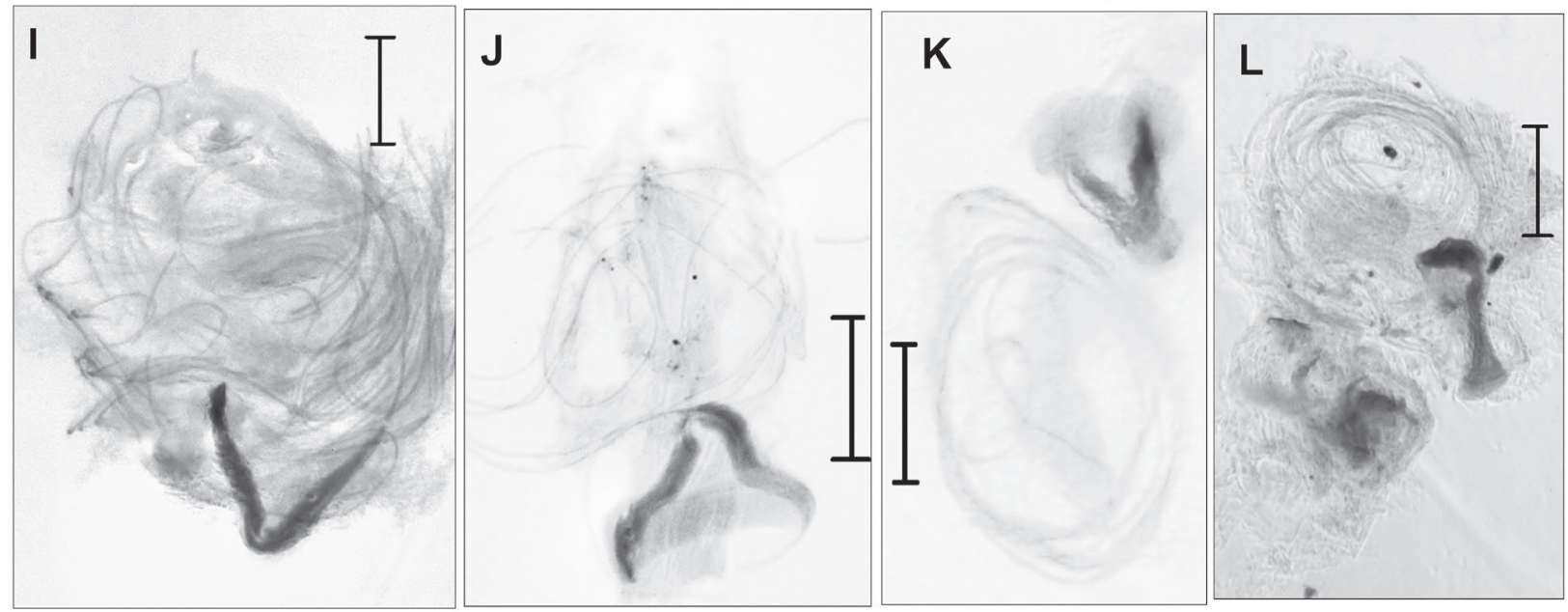

Fig. 39: Spermathecae of Diochus inornatus-group: D. schuelkei (A), D. plaumanni (B), D. tricolor (C), D. vicinus (D); Diochus maculicollis-group: D. brooksi (E), D. ecuadoriensis (F), D. maculicollis (G), D. pumilio (H), D. peruvianus (I), D. mexicanus (J), D. panamaensis (K); Diochus schaumii-group: D. angustiformis (L); scale bar: $0.1 \mathrm{~mm}$. 
Quito, $1300 \mathrm{~m}$ elevation, banana dull berlesate, 3 females, 23.12.1991, leg. C. Carlton, R. Leschen \#72 (KNHM); Pichincha, 17 km SE Sto. Domingo de los Colorados, Tinalandia, $3000 \mathrm{ft}$ elev., litter, 7 males, 22 females, 16.-21.10.1988, leg. L. Herman, (23 AMNH, 6 UIC); $40 \mathrm{~km}$ NW Sto. Domingo de los Colorados, $1200 \mathrm{ft}$. elev., litter, 8 males, 12 females, 19.10.1988, leg. L. Herman (19 AMNH, 1 UIC); $47 \mathrm{~km}$ S. Santo Domingo, Rio Palenque St., forest litter, Berlese, $700 \mathrm{ft}$. elev., 18.-30.5.1975, leg. S. Peck (FMNH); Sucumbios, Sacha Lodge $\left(76^{\circ} 05^{\prime} \mathrm{W}, 0^{\circ} 05^{\prime} \mathrm{S}\right), 270$ m elevation, malaise trap, male, 4.-14.3.1994, female, 24.3.-3.6.1994, male, 25.7.-3.8.1994, 2 females, 13.-23.4.1994, leg. Hibbs (4 KNHM, 1 UIC); Las Palmeras, old Quito-Sto. Dgo. rd., $\mathrm{km}$ 59, $43 \mathrm{~km}$ NE Alluriquin, litter, female, 23.10.1988, leg. L. Herman (AMNH); Pastaza, $20 \mathrm{~km}$ NW Puyo, $4000 \mathrm{ft}$ elev. litter nr. stream, female, 5.11.1988, leg. L. Herman (AMNH); Napo, $81 \mathrm{~km} \mathrm{NE}$
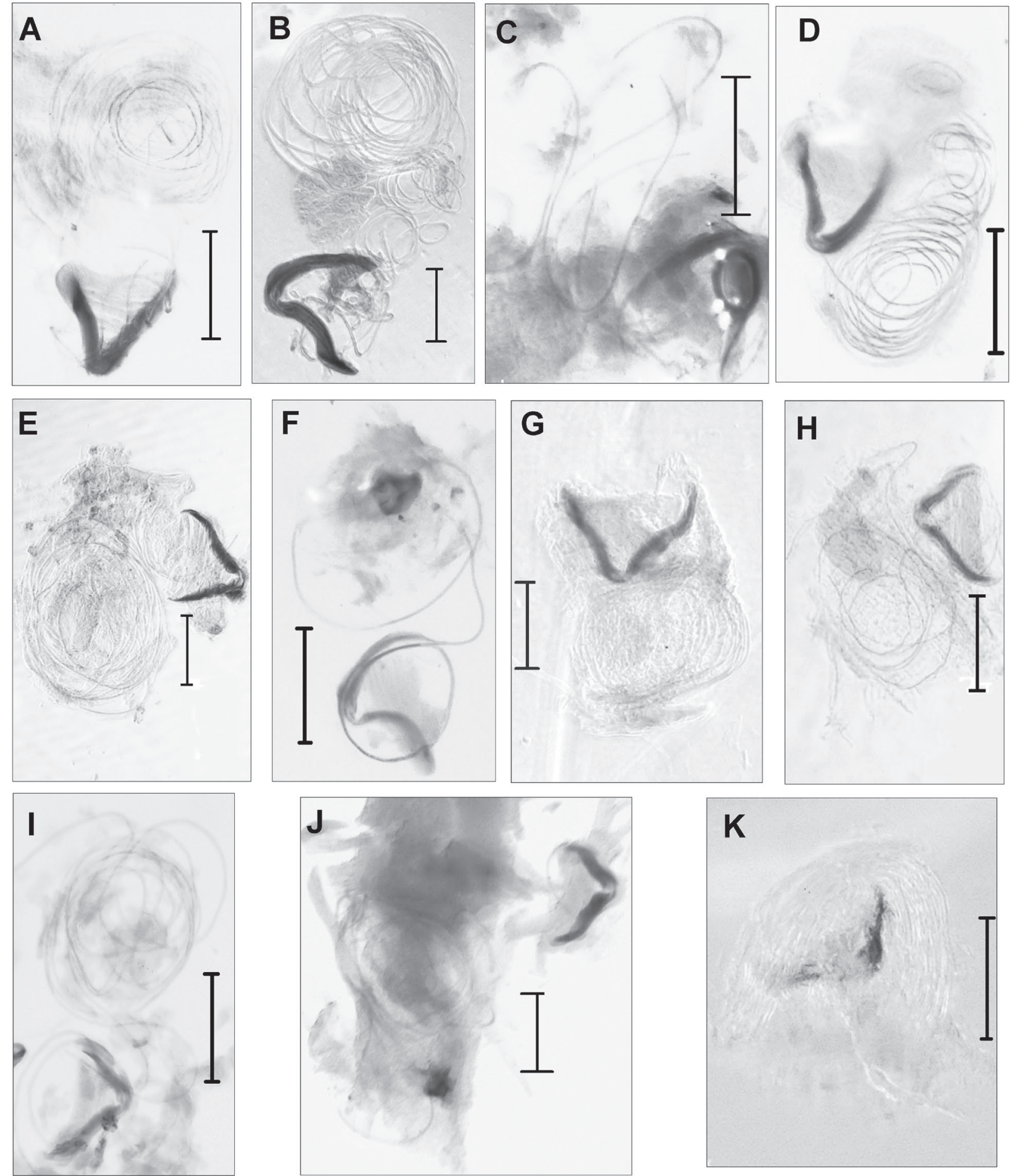

Fig. 40: Spermatheca of Diochus schaumii-group: Diochus argentinae (A), D. brunneus (B), D. curtipennis (C), D. schaumii (D), D. verhaaghi-group: D. verhaaghi (E), D. santacatarinae (F), D. nanus-group: D. perplexus (G), D. parvulus (H), D. nanus (I), D. apicipennis (J), D. formicetorum (K); scale bar: $0.1 \mathrm{~mm}$. 
Baeza, $3 \mathrm{~km}$ SW Reventador, $5300 \mathrm{ft}$. elev., litter, 28.-29.10.1988, leg. L. Herman (AMNH); Cotopaxi Prov., Guasaganda, $500 \mathrm{~m}$ elev., male, 1.4.1988, leg. M. Huybensz (FMNH); Peru: Huanuco, Llullapichis, Panguana Station $\left(74^{\circ} 56^{\prime} \mathrm{W}, 9^{\circ} 37^{\prime} \mathrm{S}\right)$, cattle pasture, pitfall trap \# 329, \#271, \#1, 1 male, 2 females, 3.9.1975, 28.5.1976, 20.5.1976, leg. W. Hanagarth (UIC); same location, but manihot field, 1 male, 1 female, 4.5.1976, leg. W. Hanagarth (UIC); same location, but herb stand at river margin, pitfall trap \# 188, female, 6.5.1976, leg. W. Hanagarth (UIC); Tambopata Prov., $15 \mathrm{~km}$ NE Pto. Maldonado, compost pile, $200 \mathrm{~m}$ elevation, male, 19.6.1989, leg. J. Ashe, R. Leschen, \#148 (KNHM).

Diagnosis: Without analysis of the paramere, Diochus perplexus Cameron, 1922 is hardly to distinguish
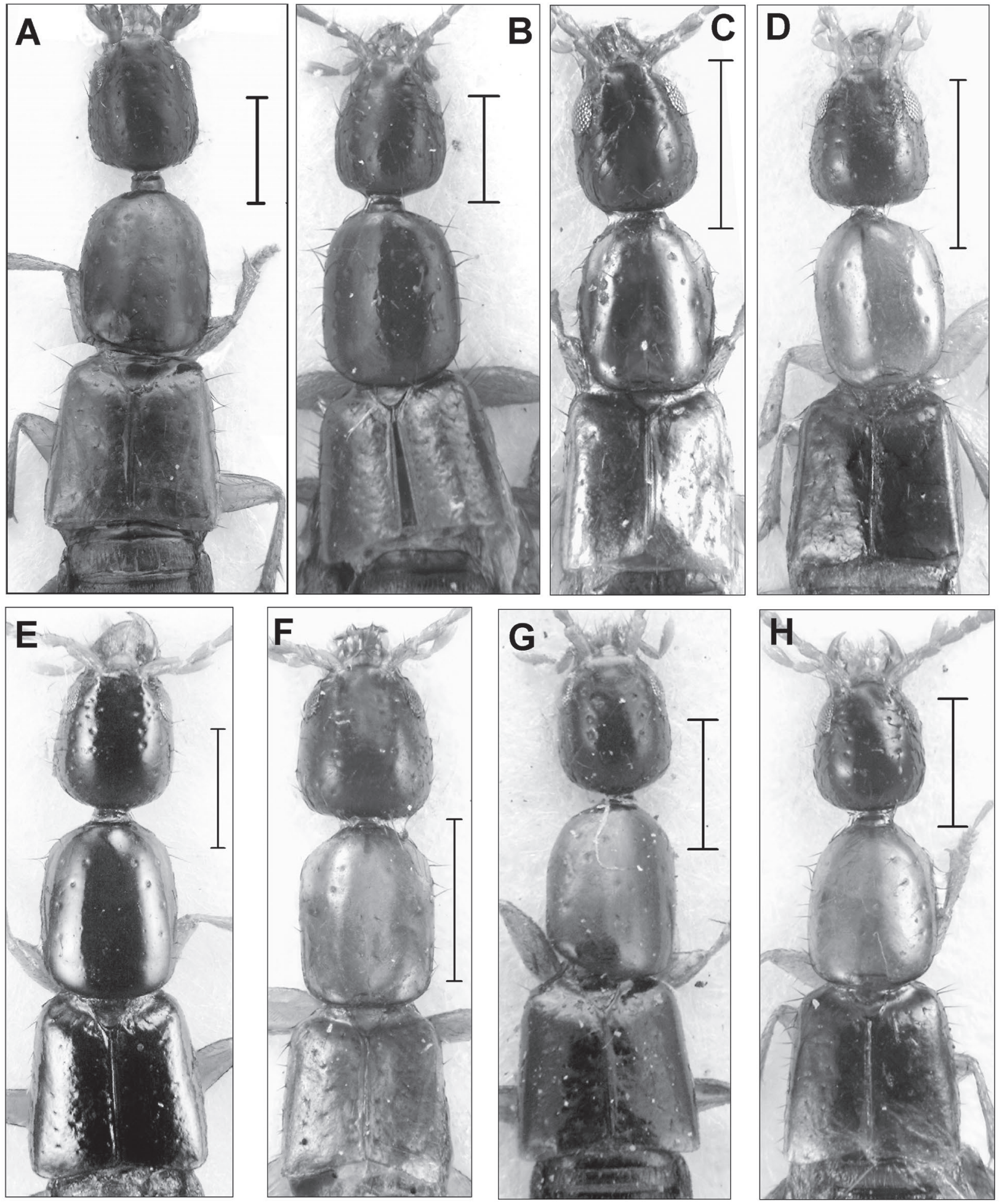

Figs 41: Fore-bodies of Diochus longicornis (A), D. tarsalis (B), D. adisi (C), D. ashei (D), D. guianensis (E), D. unicolor (F), D. inornatus $(\mathrm{G})$, D. hanagarthi $(\mathrm{H})$; scale bar: $0.5 \mathrm{~mm}$. 
from the related species D. nanus ERICHSON, 1839. Both species are clearly separated by the apex of the paramere that is deeply emarginate and bifurcate with long setae on each lobe in D. perplexus, whereas it is shortly emarginate with short apical setae in $D$. nanus. In contrast to $D$. nanus, the pronotum of $D$. perplexus is without microsculpture, except remains of micro-striae in some specimens, but has sparse micro-punctation. On average, $D$. perplexus seems to be slightly darker yellow to light brown compared to D. nanus.
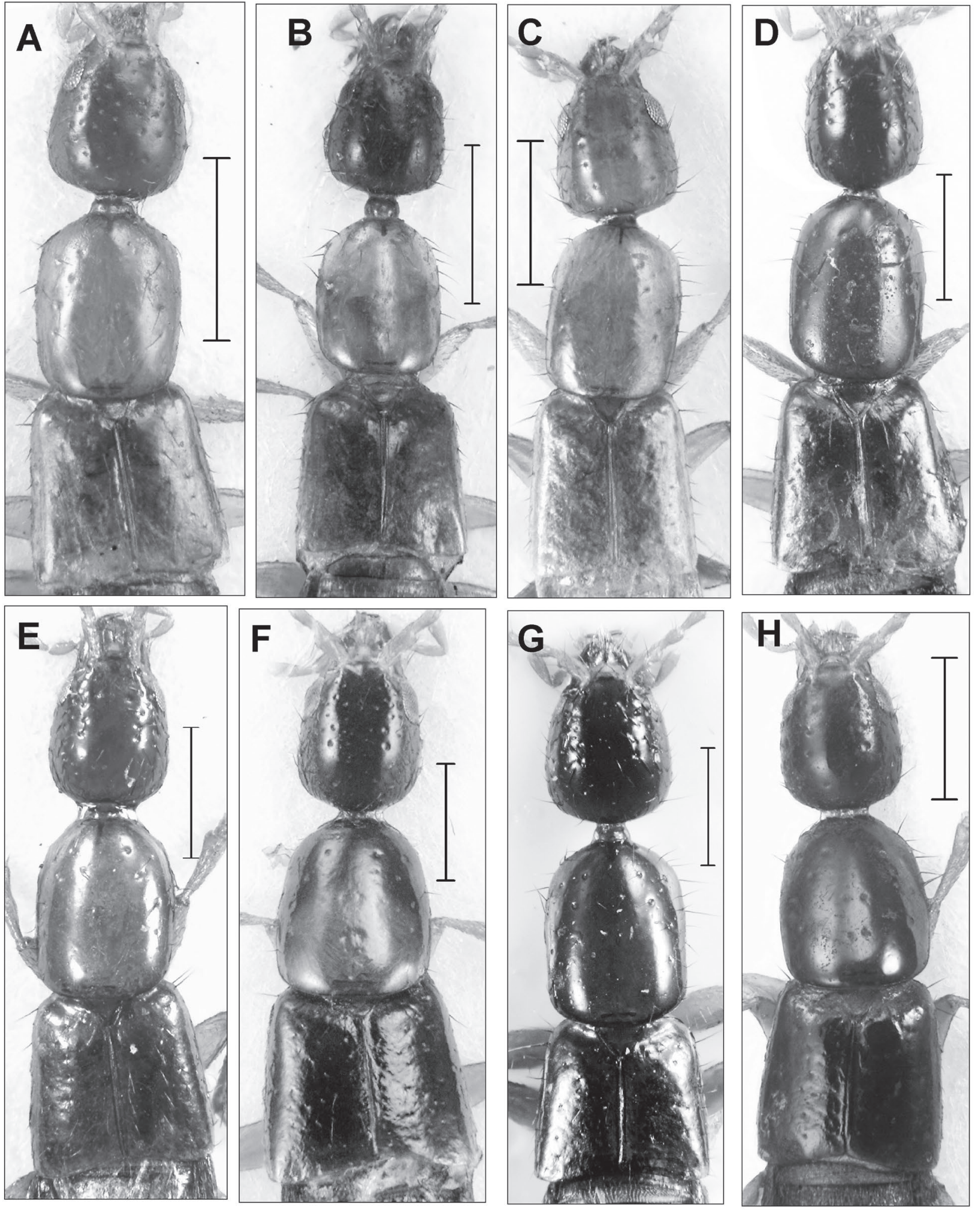

Figs 42: Fore-bodies of Diochus antennalis (A), D. tricolor (B), D. amazonensis (C), D. hermani (D), D. plaumanni (E), D. hibbsi (F), D. newtoni (G), D. novus (H); scale bar: $0.5 \mathrm{~mm}$. 
Description: Length: $2.6-2.8 \mathrm{~mm}$. Colouration: dark yellow to light brownish; head slightly darker, elytra dark with extreme posterior margin lighter, legs and antennae yellow with antennomeres four to eleven dark; darkness of colouration varies from mainly yellow to dark brown.

Head: $0.41 \mathrm{~mm}$ long, $0.37 \mathrm{~mm}$ wide; eyes not prominent; temples twice as long as eyes; $\mathrm{EL}: \mathrm{HL}=0.27$; temples distinctly divergent posteriad; $\mathrm{PW}: \mathrm{EW}=1.24$; posterior angles widely rounded; posterior width 2.5 time as wide as neck; setiferous punctation deep and moderately dense; irregular row of five to six punctures adjacent to wide impunctate midline; interstices between apical punctures approximately as wide as diameter of punctures, on posterior vertex nearly twice as wide as diameter of punctures; between medial row of punctures and eyes
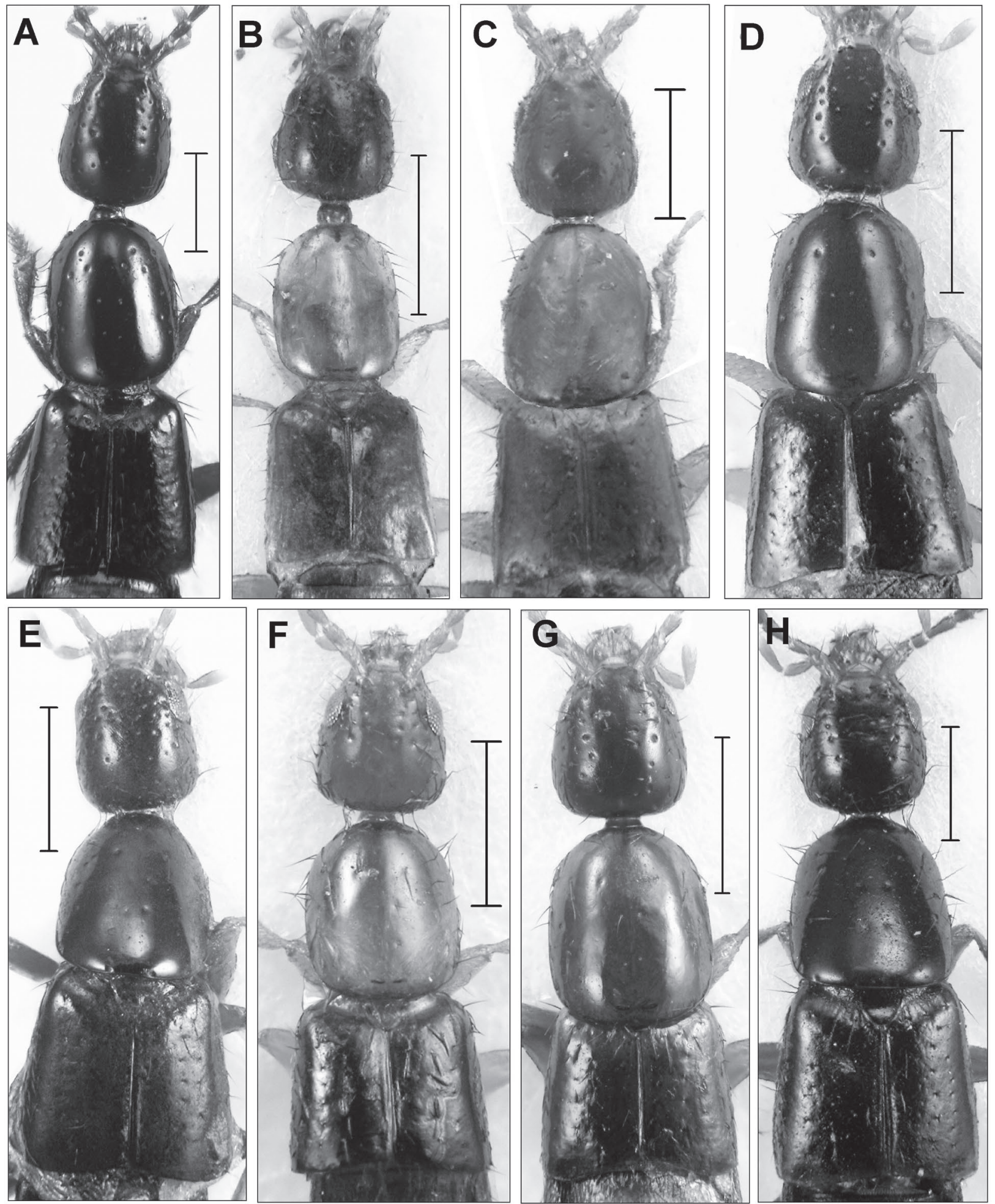

Figs 43: Fore-bodies of Diochus schuelkei (A), D. tricolor (B), D. vicinus (C), D. brooksi (D), D. ecuadoriensis E), D. maculicollis (F), D. mexicanus $(\mathrm{G})$, D. peruvianus $(\mathrm{H})$; scale bar: $0.5 \mathrm{~mm}$. 
two additional rows; postocular area with further setiferous punctures; indistinct microsculpture isodiametric; surface slightly shiny.

Antennae as long as head and one third of pronotum combined; antennomeres one to three equal in length; first antennomere thick, two and three conical; nearly twice as long as its apical width; fourth and fifth antennomere approximately quadrate; sixth to tenth wider than long; eighth nearly twice as wide as long; tenth one third wider than long; all antennomeres pubescent and with
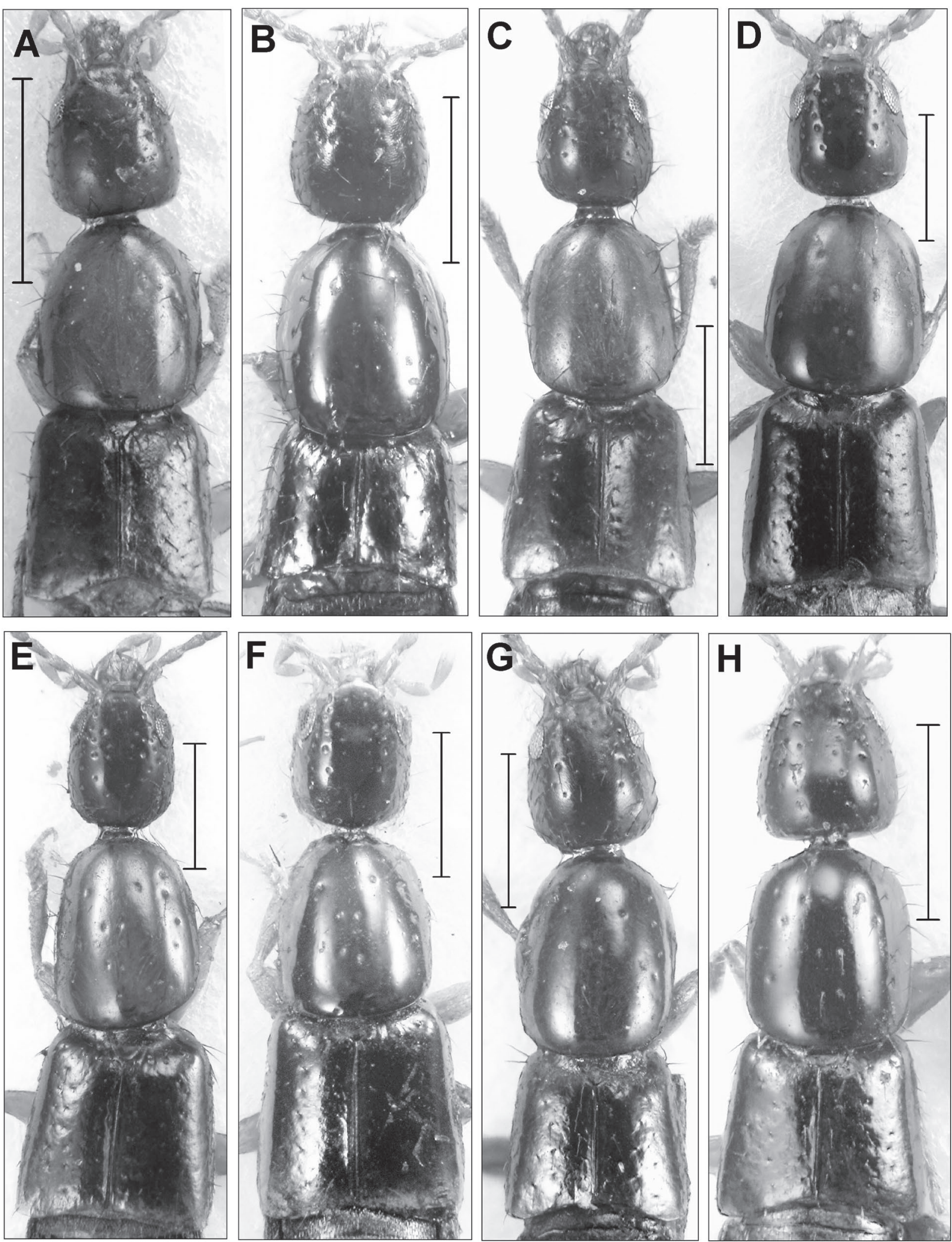

Figs 44: Fore-bodies of Diochus pumilio (A), D. panamaensis (B), D. angustiformis (C), D. brunneus (D), D. schaumii (E), D. argentinae $(\mathrm{F})$, D. curtipennis $(\mathrm{G})$, D. verhaaghi $(\mathrm{H})$; scale bar: $0.5 \mathrm{~mm}$. 
few long setae; setae of basal antennomeres thicker and longer than of apical antennomeres.

Pronotum: $0.54 \mathrm{~mm}$ long, $0.45 \mathrm{~mm}$ wide; sides parallel; anterior and posterior angles widely rounded; lateral
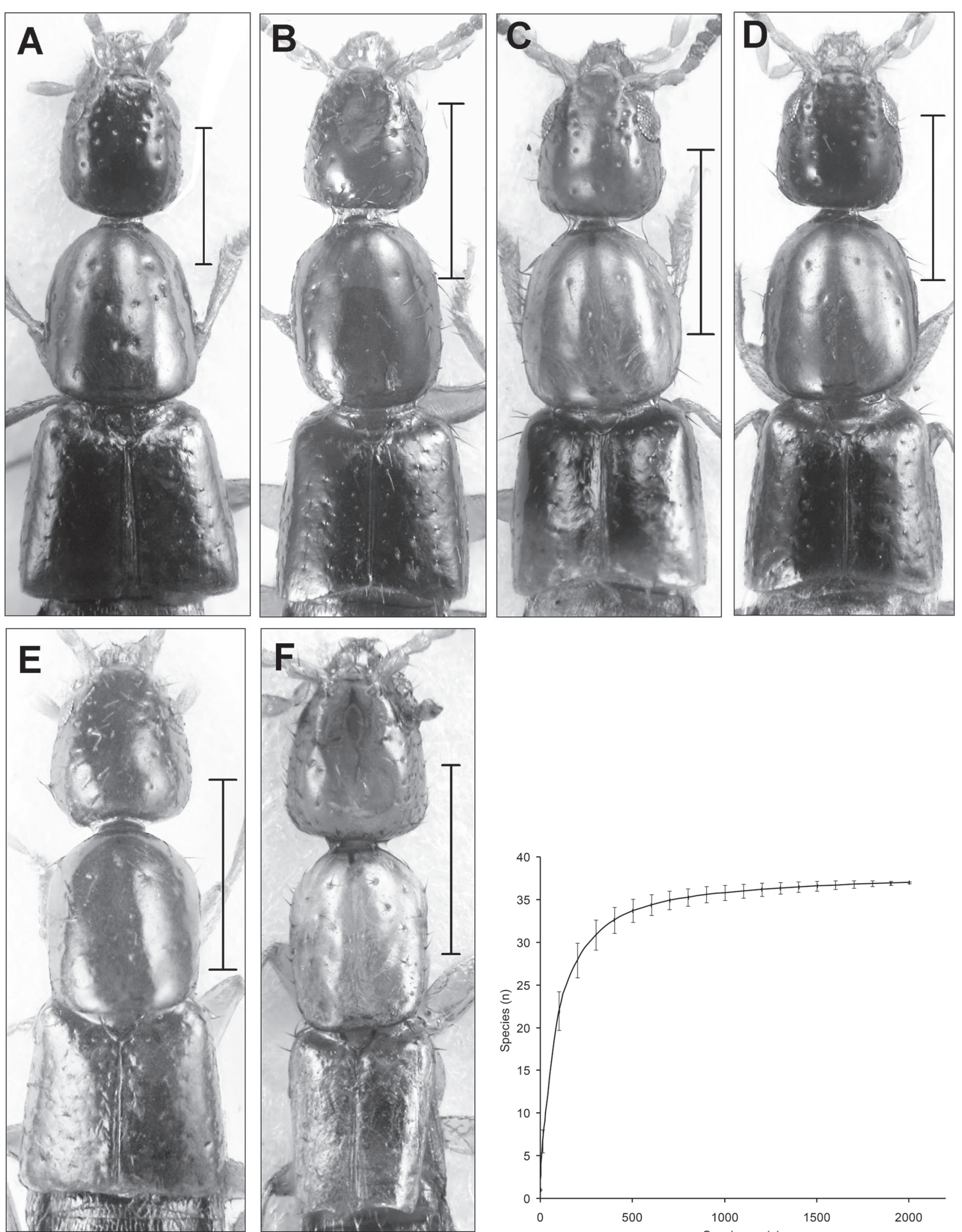

Figs 45: Fore-bodies of Diochus santacatarinae (A), D. perplexus (B), D. parvulus (C), D. nanus (D), D. apicipennis $(\mathrm{E})$, D. formicetorum $(\mathrm{F})$; scale bar: $0.5 \mathrm{~mm}$. margin extremely fine; in dorsal aspect, only visible in posterior half; setiferous punctation moderately deep and sparse; adjacent to impunctate midline with row of three pairs of punctures; interstice between anterior

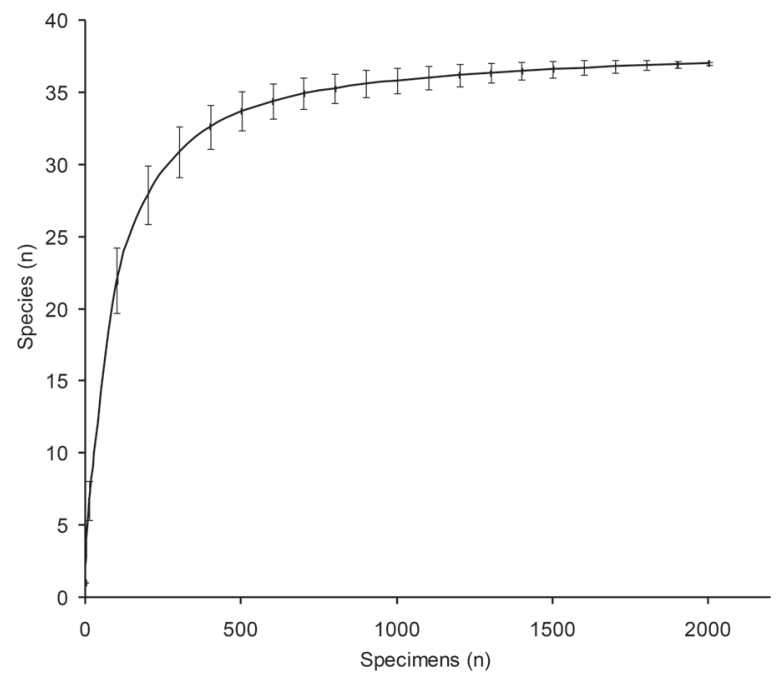

Fig. 46: Results of the rarefaction analysis with the 2016 specimens studied. 
pair nearly twice as wide as between posterior pairs of punctures; laterad with few punctures; number of punctures irregular; varying between four to eight; without microsculpture; with sparse micro-punctation, surface polished.

Elytra: $0.52 \mathrm{~mm}$ long, $0.56 \mathrm{~mm}$ wide; sides divergent to posterior angles; distinct shoulders with obtuse angles;
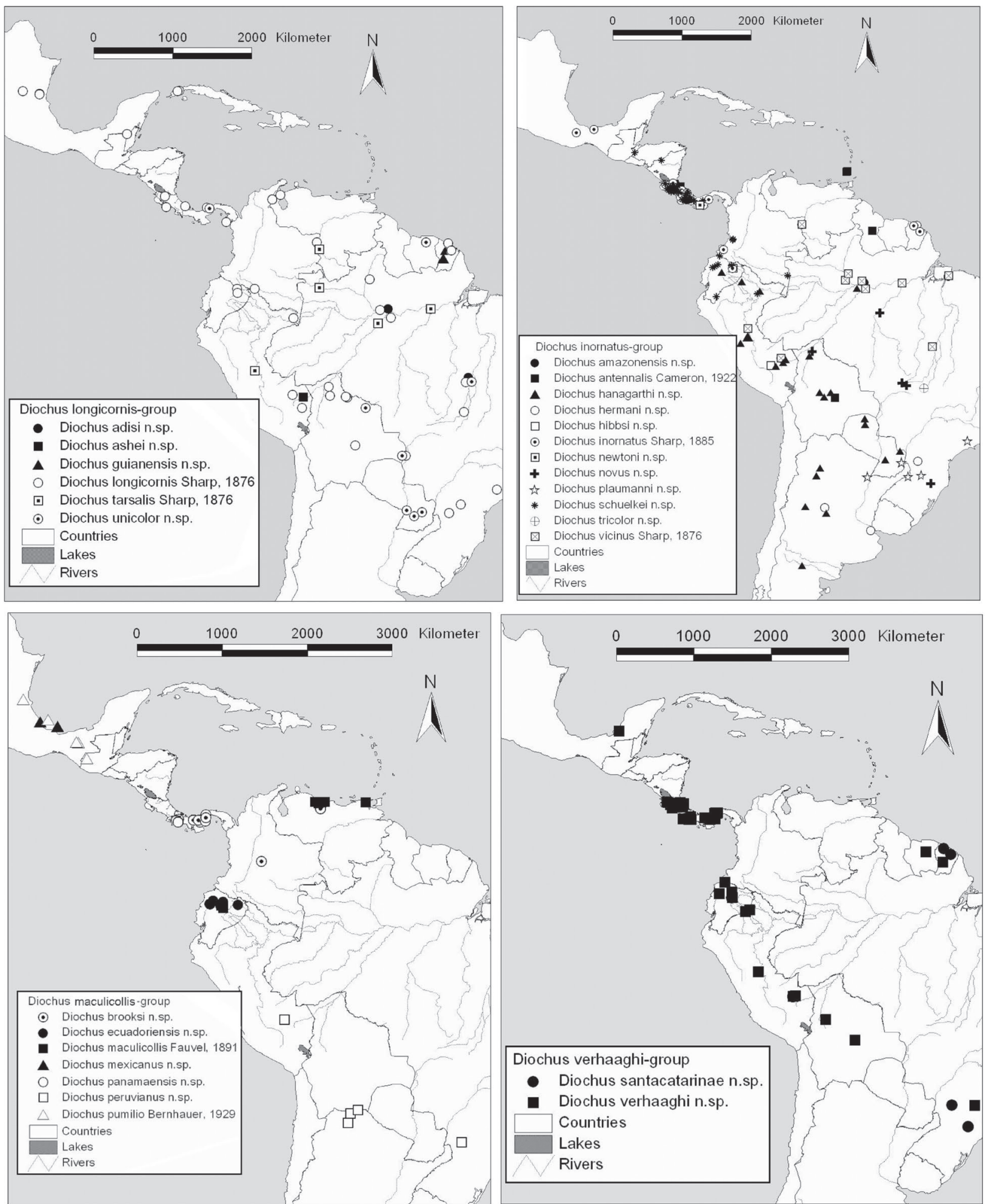

Fig. 47: Geographic distribution of the species of the D. longicornis-group, D. inornatus-group, D. maculicollis-group, and D. verhaaghi-group. posterior margin slightly emarginate; setiferous punctation in irregular longitudinal rows of seven to eight punctures; first row adjacent to suture; on disc, three more rows laterad to first row; extremely weak coriaceous ground sculpture; surface slightly less shiny than pronotum.

Abdomen densely pubescent. 
Aedeagus broad; seminal vesical of endophallus slightly short than half the length of central lobe; basal inner duct looped; ending in irregularly sclerotised forceps; paramere slightly shorter than central lobe; narrow shaft extremely widened to apex ending in two apical prominences separated by deep concave emargination; interstice between two apical prominences more transparent than laterally; each apical prominence with long seta; outer margin with third subapical seta; basal shaft with six sensillae.

Spermatheca $0.26 \mathrm{~mm}$ long, $0.20 \mathrm{~mm}$ long wide; bursa copulatrix in lateral position to coiled duct; duct irregularly coiled.

\section{Species of unclear group}

\section{Diochus formicetorum BeRnHAUER, 1927 Figs 40K, 45F}

Diochus formicetorum BERNHAUER, 1927: 244

Type material: female, Holotype: Argentina, Santa Fé, Five Lille, with Acromyrmex heyeri, leg. Weiser (FMNH).

Additional material studied: Paraguay: Guairá, Melagarejo, Tacuara Creek, flood detritus, female, 20.10.1994, leg. U. Drechsel (KNHM).

Diagnosis: Only two females of Diochus formicetorum could be studied. However, they are clearly differentiated from the other Neotropical species of Diochus by its small eyes, the distintly divergent head, and the light colouration. The other species with such small eyes are darker, e.g. D. newtoni, D. verhaaghi, or have shorter eyltra, e.g. D. mexicanus, D. panamaensis. The shape of the spermatheca let suppose that the species belongs to the D. inornatus-group.

Description: Length: $2.9 \mathrm{~mm}$. Colouration: yellow; abdomen light brown.

Head: $0.41 \mathrm{~mm}$ long, $0.38 \mathrm{~mm}$ wide; eyes not prominent; small; $\mathrm{EL}: \mathrm{HL}=0.14$; temples distinctly divergent posteriad; $\mathrm{PW}: \mathrm{EW}=1.31$; setiferous punctation moderately deep and dense; adjacent to impunctate midline with row of five punctures; between medial row and eyes two rows of supraocular punctures; temples distinctly denser punctate than vertex; partly with remains of transverse microsculpture; mostly polished.

Antennae slightly longer than head and half of pronotum combined; first antennomere twice as long as apical width; wider at apex than at base; second and third antennomere conical; nearly twice as long as apical width; fourth to tenth antennomere decreasing in length and slightly increasing in width; fourth antennomere approximately quadrate; tenth antennomere nearly twice as wide as long; all antennomeres pubescent and with short apical setae.

Pronotum: $0.46 \mathrm{~mm}$ long, $0.36 \mathrm{~mm}$ wide; widest in anterior third; apical third smoothly curved; nearly semicircular; posterior half slightly narrowed to posterior angles; posterior angles obtusely curved; lateral margin fine; in dorsal aspect visible in posterior third; setiferous punctation sparse; along impunctate midline with row of three pairs of punctures; interstice between anterior pair more than twice as wide as interstices between posterior pairs of punctures; laterad few more setiferous punctures; along lateral margin several setiferous punctures; without microsculpture; surface polished.
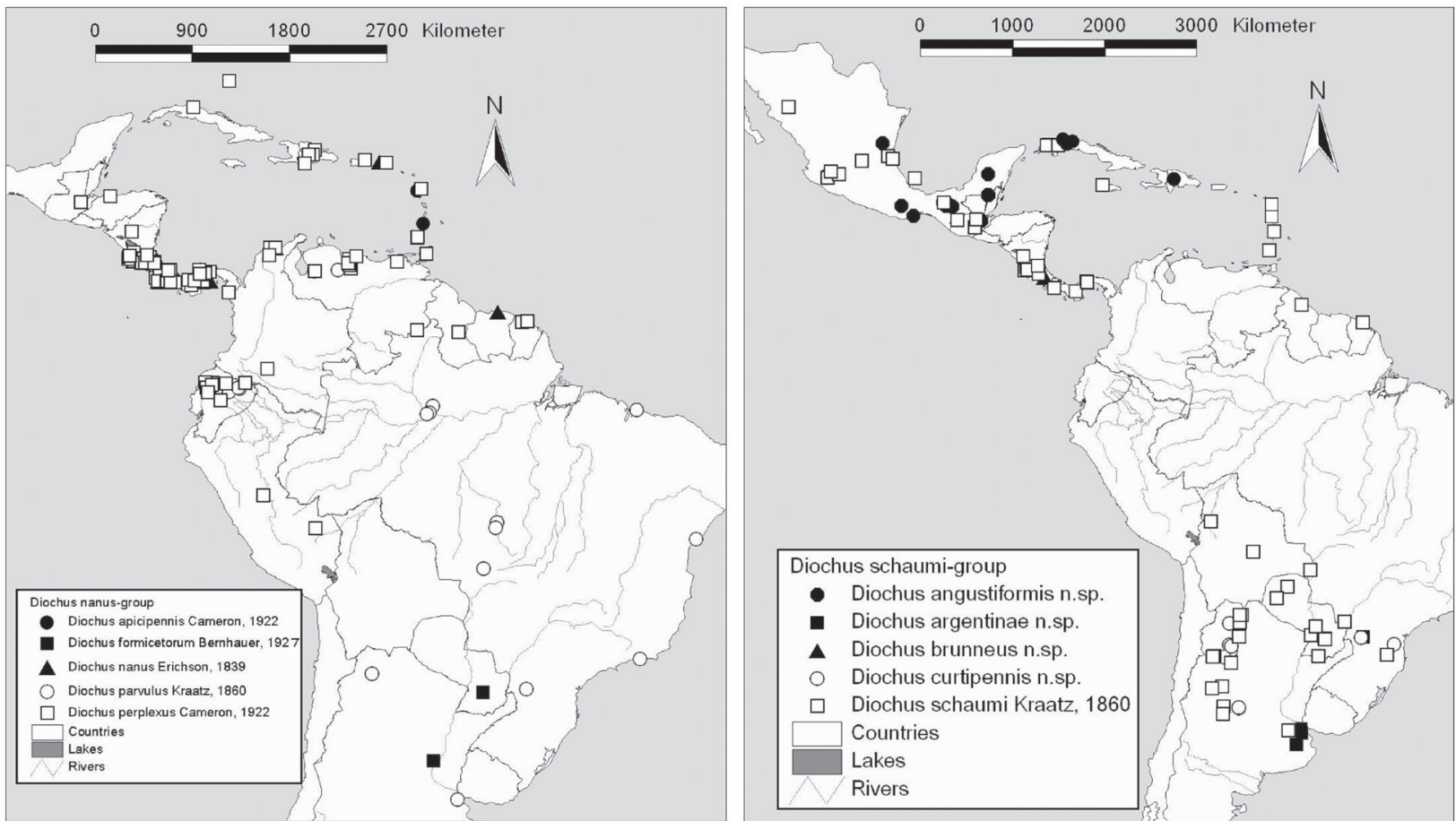

Fig. 48: Geographic distribution of the species of the D. nanus-group, D. schaumii-group, and of D. formicetorum. 
Elytra: $0.47 \mathrm{~mm}$ long, $0.38 \mathrm{~mm}$ wide; shoulders obtusely angled; sides parallel; posterior angles rectangular; setiferous punctation in irregular rows; inner row adjacent to suture line; two more rows on disc with five punctures; along lateral margin with several setiferous punctures; surface with weak coriaceous ground-sculpture; surface slightly less shiny than pronotum and head.

Abdomen with dense pubescence.

Aedeagus unknown.

Spermatheca $0.21 \mathrm{~mm}$ in diameter; bursa copulatrix in central position to coiled duct; coiled duct forming circle.

\section{Discussion}

A total of 37 species is now known from the Neotropical region. They can be grouped to at least six species groups that are mainly differentiated by the structure of the aedeagus, in particular, the shape of the paramere. A rarefaction analysis exhibits a nearly steady state status for the totally 2016 specimens studied (Fig. 46). This means that only few species can be expected from further sampling efforts. Regarding the relation among the groups, the D. longicornis-group and the D. inornatus-group seem to be closer related. In both groups an apical filament is present that is longer and with more coils in the D. longicornis-group (Fig. 1C) and shorter and with only one coil in the D. inornatus-group (Fig. 1E). In both groups the spermatheca is large and the duct has numerous coils (Figs 38A-39D). The bursa copulatrix is in a central position. Total length, length of antennae, and length of eyes vary in both groups.

A closer relation also exists between the D. nanus-group and the D. schaumii-group. In these two groups a large seminal vesical exists similar as in the D. longicornisgroup and the $\mathrm{D}$. inornatus-group. In contast to the latter groups, the $\mathrm{D}$. nanus-group and the $\mathrm{D}$. schaumii-group are characterised by the absence an apical filamentous duct (Fig. 1D), a widended paramere at apex, an irregularly coiled duct of the spematheca, and a marginal position of the bursa copulatrix (Figs 39L-40D, 40G-J). Comparing the New World Diochus species with the two species known from the Western Palearctic as graphed by Assing (2003), the differences in the structure of the aedeagus are evident. Both Palearctic species seem to have no thick seminal vesical as it is present in all Neotropical species. The spermatheca of at least one species, D. staudinger KRAATZ, 1860, shows high similarities with the species of the D. longicornis- and D. inornatus-groups.

Most species in the Neotropical region are living in the litter layer of different ecosystems. More than $31 \%$ of the items have the information that the specimens were found in the litter layer, either of forests or grassland. Another $8 \%$ was found at deacying logs. The high affinity to the soil layer might be the cause why species were also found in caves, such as D. longicornis SHARP, 1876 in Mexico. However, few species seem to prefer vegetation layers. Diochus nanus ERICHson, 1839, might live in upper vegetation layers, because more than $70 \%$ of the items were caught by sweeping or by car net. Diochus brunneus and D. antennalis CAMERON, 1922 were also found only be car net, Malaise trap or by flight intercept traps.

The analysis of the geographic pattern exhibits wide or endemic distributions. The species of three groups were not found in the lowland rainforest of the large Amazon Basin: They represent the Circum-Amazonian distribution as found in many other groups of Staphylinidae (IrmLer 2009). These are the D. verhaaghi-group, D. maculicollis-group, and D. schaumii-group (Figs 47, 48). The distribution of D. schaumii Kraatz, 1860 is enigmatic. The species is widely distributed from the USA (Smetana 1982, Frank et al. 2014) via Mexico to southern Central America, a gap in the equatorial region, and another close areal unit from Boliva, Paraguay, southern Brazil, and northern Argentina. This pattern can be explained either by the existance of populations in the equatorial Andes that is still not found or by the invasion from the large northern population to the southern region with similar climatic conditions as in the north or vice versa. At least two closely related species to D. schaumii are endemic in the southern areal unit and indicate that ancestors of the group existed in southern South America: D. curtipennis and D. argentinae. D. brunneus from Panama is another species of the group with a closely restricted distribution in Central America. The species of the D. maculicollisgroup have a close affinity to the soil layer that is already expressed by the small eyes found in many species of the group. This might be the reason why most species of the group show a close areal unit. In the North D. mexicanus and $D$. pumilio were recorded only from Mexico. In southern Central America D. panamaensis occurred in Panama, D. brooksi in Panama, Columbia, Venezuela, and D. ecuadoriensis in Ecuador. D. peruvianus, only, has a wide distribution from Peru to Argentina and southern Brazil.

The D. longicornis-group, the D. nanus-group, and the species-rich D. inornatus-group are widely distributed including the large Amazon Basin. Among the species of the D. nanus-group, D. perplexus CAMERoN, 1922 represents the group mainly in Central America including the West Indies and Bahamas and north-western South America, whereas D.parvulus KRAATZ, 1860 replaces this species in the Amazon Basin and in south-eastern South America. Additionally to D. perplexus, the endemic D. apicipennis is found on the West Indian islands. The species of the D. longicornis-group are mainly distributed in the lowland rainforest of the Amazon Basin, except D. longicornis SHARP, 1876 that occurs from southern Brazil to Mexico. The species of the D. inornatus-group are distributed from northern Argentina (D.hermani) to Guatemala (D. schuelkei). 


\section{Key to the species (males)}

1 Seminal duct of aedeagus ending in long filament with several wide coils (Fig. 1C)

- Seminal duct of aedeagus not ending in long filament with several wide coils; if filament is present it has one short coil (Figs 1E, D)

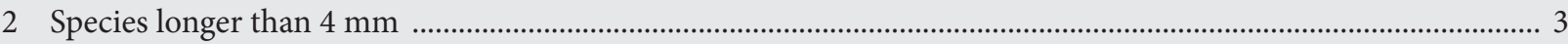

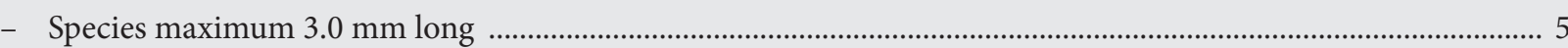

3 Seminal vesical of aedeagus thick, nearly globular and less than half as long as central lobe (Fig. 5A); antennae as long as head and half of pronotum combined (Fig. 5C) D. guianansis spec. nov.

- Seminal vesical of aedeagus at least half as long as central lobe (Figs 2A, 3A), antennae longer (Figs 2C, 3C) ...

Seminal duct of aedeagus approximately haf long as central lobe (Fig. 2A); antennae nealy as long as head and

4 Seminal duct of aedeagus approximately half long as central lobe (Fig. 2A); antennae nearly as long as head and pronotum combined (Fig. 2C) D. longicornis SHARP, 1876

- Seminal duct of aedeagus longer than half as long as central lobe (Fig. 3A); slightly longer than head and half of pronotum combined (Fig. 3C)

D. tarsalis SHARP, 1876

5 Eyes large, temples only 1.6 times as long as eyes (Fig. 41C)

D. adisi spec. nov.

- Eyes shorter, temples at least twice as long as eyes (Fig. 41D, F)

6 Eyes larger, temples twice as long as eyes (Fig. 41D); paramere curved in apical third (Fig. 6B)

D. ashei spec. nov.

- Eyes shorter, temples 2.6 times as long as eyes (Fig. 41F); paramere straight (Fig. 7B) ......... D. unicolor spec. nov.

7 Basal inner duct of aedeagus ending in funnel-like structure; filamentuous apical inner duct shortly coiled (Fig. 1E)

Without apical inner duct (Fig. 1D)

8 Seminal vesical extremely thick and long, two third as long as central lobe, paramere slender and short, without processes (Figs 8A, B, 9A, B)

- Seminal vesical shorter, only slightly longer than half as long as total length of central lobe (Figs 10A-19A) ...... 10

9 Head longer; length : width ratio approximately 1.3; temples 2.5 times as long as eyes (Fig. 41G); seminal vesical nearly three quarter as long as total length of central lobe (Fig. 8A) D. inornatus SHARP, 1885

- Head shorter; length : width ratio of approximately 1.15; temples only 1.8 times as long as eyes (Fig. 41H); seminal vesical slightly shorter (Fig. 9A) D. hanagarthi spec. nov.

10 Large, at least $4.7-5.0 \mathrm{~mm}$ long; black; paramere with long triangular process in front of apex (Figs 14B, 19B) .... .

- Smaller; not longer than $4.5 \mathrm{~mm}$, dark brown or lighter; paramere without long triangular process in front of apex

11 Eyes larger, $\mathrm{HL}: \mathrm{EL}=0.21$ (Fig. 43A), long apical process of paramere triangularly erect (Fig. 14B)

D. schuelkei spec. nov.

- Eyes smaller, HL : EL = 0.15 (Fig. 42G), long apical triangular process of paramere spoon-like (Fig. 19B)

D. newtoni spec. nov.

12 Antennae long; nearly as long as head and pronotum combined

- Antennae shorter; as long as head and half of pronotum combined; dark brown with pronotum slightly lighter brown; seminal vesical elongate

13 Longer than $4 \mathrm{~mm}$, black with posterior half of pronotum light brown (Fig. 42F), seminal vesical thick, nearly globular, paramere with short triangular process at apex (Figs 17A, B) D. hibbsi spec. nov.

- Smaller than $4 \mathrm{~mm}$, yellow (Fig. 42C), seminal vesical elongate, oval, paramere simply widened at apex, without process (Figs 16A, B) D. amazonensis spec. nov. 
14 Larger, approximately $4.3 \mathrm{~mm}$ long; paramere with long apical process at apex .............................................. 15

- Shorter than $4.0 \mathrm{~mm}$, paramere without or with short apical process .................................................................... 16

15 Pronotum light orange, head wider; only 1.15 times as long as wide (Fig. 43C); apical process of paramere with apical hook (Fig. 10C)

D. vicinus SHARP, 1876

- Pronotum not lighter than head; head more slender; 1.35 times as long as wide (Fig. 42 D), apical process of paramere shorter and without hook (Fig. 15B)

D. hermani spec. nov.

16 Larger, 3.6-3.8 mm long

- Smaller, 3.0 to $3.1 \mathrm{~mm}$ long

18

$173.6 \mathrm{~mm}$ long, paramere with acute, hook-like process at apex pointing backwards (Fig. 12B), pronotum as brown as head D. novus spec. nov.

- $3.8 \mathrm{~mm}$ long, paramere with short obtuse, straight process at apex (Fig. 18B), pronotum lighter brown than head D. plaumanni spec. nov.

18 Paramere apically not widened (Fig. 13B), head black, pronotum yellow, eyes slightly wider HL : EL 0.25 (Fig. 42B)

D. tricolor spec. nov.

- Paramere apically with slight apical widening (Fig. 11B), head light brown, pronotum slightly lighter brown, HL : EL 0.22 (Fig. 42A) D. antennalis CAMERoN, 1922

19 Parameres of aedeagus apically curved and encompassing central lobe (Figs 20B-26B) 20

- Parameres of aedeagus slender straight, at least slightly widened at apex, not curved and encompassing central lobe (Figs 27B-37B)

20 Small species of approximately $2.5 \mathrm{~mm}$ length, seminal duct not looped; slightly sinuate, pointing anteriad (Fig. 25A) D. pumilio Bernhauer, 1929

- Species, at least $3.2 \mathrm{~mm}$ long, seminal duct looped as in all other Diochus species 21

21 Species more than $4.5 \mathrm{~mm}$ long, antennae totally black except the three lighter basal antennomeres (Fig. 23C) .... D. peruvianus spec. nov.

- Smaller species, shorter than $4.0 \mathrm{~mm}$, antennae with at least few apical antennomeres light brown or yellow 22

22 Head and pronotum orange or light yellow, apical four antennomeres light yellow (Fig. 22C)

D. maculicollis FauveL, 1891

- Head and pronotum black as elytra, less than four apical antennomeres yellow

23 Head elongate, at least 1.4 times as long as wide (Fig. 43E), paramere with triangular process (Fig. 21B) D. ecuadoriensis spec. nov.

- Head quadrate, paramere slender 24

24 Elytra longer, approximately quadrate, length : width ratio 1.03 (Fig. 43D) D. brooksi spec. nov.

- Elytra shorter, wider than long, length : width ratio maximum 0.84 25

25 Elytra slightly longer, PL : EL = 0.84 (Fig. 43G), antennae nearly totally dark, paramere without preapical process, curved part shorter (Fig. 24C) D. mexicanus spec. nov.

- Elytra shorter, PL : EL = 0.72 (Fig. 44B), antennae with at least three white-yellow apical antennomeres, paramere with preapical process, curved part longer (Fig. 26B) D. panamensis spec. nov.

26 Parameres widened at apex and bifurcate into two lobes or forming a large plate (Figs 34A-37A) 27

- Paramere symmetrically or asymmetrically widened at apex, but not bifurcate or forming a large plate 30

27 Eyes small (Fig. 45E), EL : HL ratio 0.21, paramera ending in a large plate (Fig. 37B)

D. apicipennis CAMERON, 1922

- $\quad$ Eyes larger (Figs 45B-C), EL : HL ratio 0.27-0.28, paramera bifurcate 28 
28 Yellow with anterior half of elytra black (Fig. 45C), bifurcate paramere strongly widened at apex with short medial process (Fig. 36B)

D. parvulus KraAtz, 1860

- Dark yellow to light brown, anterior half of elytra not distinctly darker than posterior half, bifurcate paramere less widened at apex and with deep incision

29 Bifurcate paramere with deep incision, incisions acute (Fig. 34B), pronotum polished without remains of microsculpture

D. perplexus CAmeron, 1922

- Bifurcate paramere with short incision, incisions obtuse (Fig. 35B), pronotum shiny with remains of microsculpture in anterior half D. nanus ERICHSON, 1839

30 Seminal vesical of aedeagus slender, more than 4 times longer than wide, seminal duct of aedeagus only shortly looped (Figs 32A, 33A)

- Seminal vesical of aedeagus thicker; only three times longer than wide; seminal duct distinctly looped, looped part reaching basic half of seminal vesical (Figs 27A-31A)

31 Larger, $3.6 \mathrm{~mm}$ long, head nearly parallel (Fig. 45A) D. santacatarinae spec. nov.

- Smaller, not longer than $3.0 \mathrm{~mm}$, head distinctly divergent posteriad (Fig. $44 \mathrm{H}$ ) D. verhaaghi spec. nov.

32 Elytra 1.15 times wider than long $(E L: E W=0.87)$; only 0.75 times as long as pronotum $(\mathrm{PL}: \mathrm{EL}=1.3)(\mathrm{Fig} .44 \mathrm{G})$ D. curtipennis spec. nov.

- Elytra nearly quadrate and as long as pronotum

33 Head nearly parallel ( $\mathrm{PW}: \mathrm{EW}=1.06-1.09)$, light brown, anterior half of pronotum not lighter than posterior half

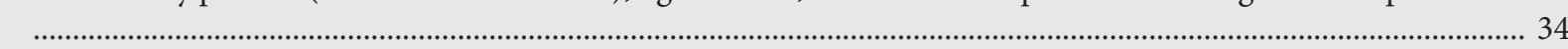

- Head more divergent ( $\mathrm{PW}: \mathrm{EW}=1.15)$, dark brown with anterior half of pronotum lighter, apical process of peramere erect and apically obtuse (Fig. 30B) D. brunneus spec. nov

34 Apical widening of paramere only slightly asymmetric (Fig. 27B) D. schaumii KRAATZ, 1890

- Apical widening of paramere strongly asymmetric

35 Apical process of paramere thick triangular (Fig. 28B), head slightly divergent (PW : EW = 1.09)

D. angustifromis spec. nov.

- Apical process obtuse, apical process more slender (Fig. 29B), head distinctly parallel (PW : EW = 1.06)

\section{Key to the species (females)}

The key to identify females can only be used as additional support. Certain identification can only be performed using males with dissection of the aedeagus and a detailed analysis of the shape of the paramere.

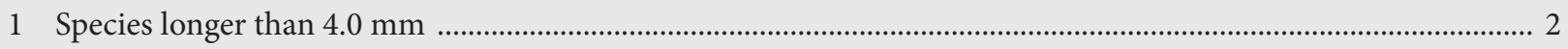

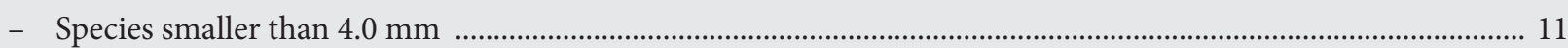

2 Black species of at least $5.0 \mathrm{~mm}$ length and EL : HL higher than 0.20 .................................. D. schuelkei spec. nov.

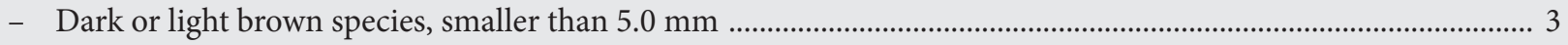

$3 \mathrm{EL}: \mathrm{HL}=0.15$, longer than $4.5 \mathrm{~mm}$ D. newtoni spec. nov.

- EL : HL higher than 2.0, 4.1-4.9 mm long 4

4 Antennae elongate, third antennomere approximately 3 times as long as wide ................................................... 5

- Antennae shorter, third antennomere 2.0-2.3 times as long as wide .................................................................. 9

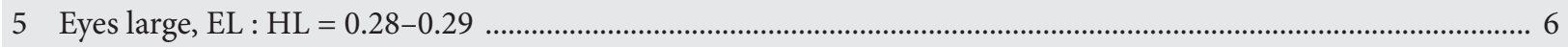

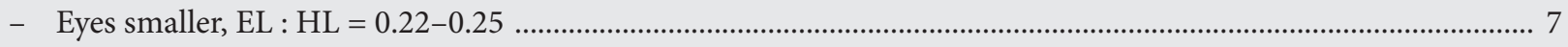


6 Black with posterior half of pronotum lighter brown D. hibbsi spec. nov.

- Brown with pronotum slightly lighter brown D. longicornis SHARP, 1876

7 Eyes slightly larger, $\mathrm{EL}: \mathrm{HL}=0.23-0.25$ 8

- Eyes slightly smaller, EL : HL $=0.22$ D. hermani spec. nov.

8 On average, shorter, $4.3 \mathrm{~mm}$ long, elytra quadrate D. vicinus SHARP, 1876

- On average, longer, 4.4.-4.6 mm long, elytra slightly wider than long, length : width ratio 0.95

D. tarsalis SHARP, 1876

9 Large species of $4.9 \mathrm{~mm}$ length, head approximately parallel, PW : EW 1.06, spermatheca with irregularly coiled duct D. peruvianus spec. nov.

- Smaller species of maximum 4.4 mm length

10 Smaller, $4.1 \mathrm{~mm}$ long, lighter brown, head parallel $(\mathrm{PW}: \mathrm{EW}=1.06)$, eyes large $(\mathrm{EL}: \mathrm{HL}=0.27)$, bursa copulatrix in lateral position to coiled duct D. schaumií KRAATZ, 1860

- Larger, $4.4 \mathrm{~mm}$ long, dark brown to black, head more divergent (PW : EW =1.19), eyes smaller $(\mathrm{EL}: \mathrm{HL}=0.25)$, bursa copulatrix in central position to shoe-like D. guianansis spec. nov.

11 Species longer than $3.0 \mathrm{~mm}$ 12

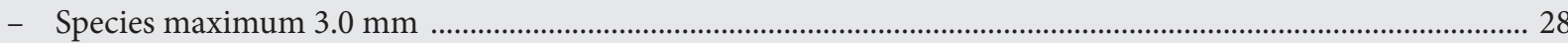

12 Elytra distinctly wider than long, pronotum at least 1.2 times as long as elytra ............................................. 13

- Elytra approximately quadrate or pronotum as long as or shorter than elytra .................................................. 17

13 Larger species, $3.8 \mathrm{~mm}$ long D. plaumanni spec. nov.

- Smaller species, not longer than $3.5 \mathrm{~mm}$ 14

14 Eyes shorter, EL : HL maximum 0.25, head more divergent, PW : EW at least 1.19

- Eyes longer, EL : HL 0.28, head less divergent, PW : EW = 1.12 D. parvulus KRAATZ, 1860

15 Eyes slightly larger, EL : HL at least 0.25 , head less divergent, PW : EW less than 1.20 .... D. curtipennis spec. nov.

- Eyes smaller, EL : HL not higher than 0.20, PW : EW at least 1.23

16 Head with deep microsculpture, pronotum nearly 1.5 times as long as elytra D. panamensis spec. nov.

- Head with weak microsculpture, pronotum only 1.2 times as long as elytra D. mexicanus spec. nov.

17 Small species, not longer than $3.2 \mathrm{~mm}$ long 18

- Larger species of at least $3.6 \mathrm{~mm}$ length 20

18 Head distinctly divergent, $\mathrm{PW}: \mathrm{EW}=1.25$, only last antennomere slightly lighter than preceeding antennomeres D. antennalis CAMERON, 1922

- Head less divergent, PW : EW maximum 1.15, antennae contrasting coloured

19 Head and pronotum light brown to yellow, apical four antennomeres light yellow contrasting to darker to antennomeres four to seven D. maculicollis FAUVEL, 1891

- Totally black, apical antennomere light yellow contrasting to darker penultimate antennomeres D. brooksi spec. nov.

20 Eyes larger, EW : HW at least 0.27

- Eyes smaller, EW : HW not higher than 0.22

21 Slightly larger, $3.8 \mathrm{~mm}$ long, with contrasting lighter pronotum D. inornatus SHARP, 1885

- Slightly shorter, $3.6 \mathrm{~mm}$ long, with pronotum not contrasting lighter 22 
22 Head slightly divergent $(\mathrm{PW}: \mathrm{EW}=1.19)$

D. novus spec. nov.

- Head more parallel (PW : EW = 1.12) D. santacatarinae spec. nov.

23 Antennae long, third antennomere three times as long as wide

D. amazonensis spec. nov.

- Antennae shorter, third antennomere only two times as long as wide or shorter

24 Totally black or dark brown and only anterior half of pronotum lighter brown

- Brown to light brown

25 Dark brown, anterior half of pronotum lighter brown, head more divergent $(\mathrm{PW}: \mathrm{EW}=1.15)$

D. brunneus spec. nov.

- Totally blackish, head more parallel (PW : EW = 1.07)

D. ecuadoriensis spec. nov.

26 Head nearly parallel (PW : EW $=1.06-1.07$ )

- Head more divergent (PW : EW = 1.18)

D. hanagarthi spec. nov.

27 Elytra longer than pronotum $(\mathrm{PL}: \mathrm{EL}=0.75)$

D. argentinae spec. nov.

- Elytra shorter than pronotum $(\mathrm{PL}: \mathrm{EL}=1.10)$

D. angustiformis spec. nov.

28 Eyes small, EL : HL maximum 0.22

- Eyes larger, EL : HL at least 0.25

29 Eyes extremly small, $\mathrm{EL}: \mathrm{HL}=0.14$ and head distinctly divergent, $\mathrm{PW}: \mathrm{EW}=1.31$

D. formicetorum BERNHAUER, 1927

- $\quad$ Eyes larger, EL : $\mathrm{HL}=0.19-0.22$, head less divergent $\mathrm{PW}: \mathrm{EW}=1.19-1.23$

30 Antennae long, as long as head and pronotum combined, third antennomere twice as long as wide

D. unicolor spec. nov.

- Antennae shorter, not longer than head and half of pronotum combined, third antennomere only 1.5 times as long as wide

31 Head distinctly divergent, $\mathrm{PW}: \mathrm{EW}=1.22$

- Head less divergent PW : EW = 1.11

D. pumilio Bernhauer, 1929

32 In total lighter, head not darker than pronotum and elytra, only posterior half of elytra slightly darkened

D. apicipennis CAMERON, 1922

- In total darker, head darker than pronotum and elytra

D. verhaaghi spec. nov.

33 Antennae nearly as long as head and pronotum combined, third antennomere at least twice as long as wide, fourth antennomere longer than wide

- Antennae not longer than head and half of pronotum combinded, third antennomere shorter, fourth antennomere quadrate or wider than long

34 Head more divergent, $\mathrm{PW}: \mathrm{EW}=1.33$, eyes smaller, temples twice as long as eyes D. ashei spec. nov.

- Head less divergent, PW : EW = 1.13, eyes larger, temples 1.6 times as long as eyes D. adisi spec. nov.

35 Head black, contrasting darker than yellow pronotum, third antennomere nearly twice as long as wide D. tricolor spec. nov.

- Head light brown to dark brown, not or only slightly darker than pronotum, third antennomere 1.5 times as long as wide

36 On average darker, pronotum totally polished, without remainings of microsculpture

D. perplexus Cameron, 1922

- On average lighter, pronotum with remainings of stritate microsculpture

D. nanus ERICHSON, 1839 
Most species exhibt no closely endemic distribution except $D$. newtoni that was only found in a close restricted area of Panama. Similar as D. perplexus and D. parvulus of the D. nanus-group, D. inornatus SHARP, 1885 and $D$. hanagarthi seem to be sister species that replace each other geographically. D. inornatus occurs in Central America, whereas D. hanagarthi was found from northwestern to south-eastern South America.

\section{References}

Bernhauer, M. 1927: Zur Staphylinidenfauna Südamerikas, insbesondere Argentiniens. 31. Beitrag. - Archiv für Naturgeschichte 91: 229-264.

Bernhauer, M. 1929: Neue Staphyliniden aus Mittelamerika. - Wiener Entomologische Zeitung 46: 186-208.

Blackwelder, R. 1944: Checklist of the coleopterous insects of Mexico, Central America, the West Indies, and South America. Part 1. - United States_National Museum Bulletin 185: 1-188 - https://repository! si.edu/handle/10088/21278.

CAMERON, M. 1922: Descriptions of new species of Staphylinidae from the Wesdt Indies. Part II. - Annals \& Magazine of Natural History 9: 113-128.

Chatzimanolis, S. \& Engel, M. 2011: A new species of Diochus from Baltic amber (Coleoptera, Staphylinidae ${ }_{2}$ Diochini). _ ZooKeys 138: 65-73 - DOI: '10.3897/' zookeys.138.1896,

ERICHSON, W. F. 1840: Genera et species staphylinorum insectorum Coleopterorum familiae. - F.H. Morin, Berolini - DOI: '10.5962/bhl.title.59644.

Fauvel, A. 1891: Voyage de M.E. Simon au Venezuela (Décembre 1887 - Avril 1888) 11. Mémoire (1) Staphylinides. - Revue francaise d'Entomologie 10: 87-127.

Hadley, A. 2006: Combine Z5.3. Public Domain software.

Herman, L. 2001: Catalog of the Staphylinidae (Insecta: Coleoptera). 1758 to the end of the millenium. V. Stpahylinine group Staphylininae, Diochini to Staphylinini. - Bulletin of the American Museum of Natural History 265: 2441-3020.

Irmler, U. 2009: New species and records of the genus Lispinus with a key to the species from Peru (Coleoptera: Staphylinidae: _ Osoriinae). _ Zootaxa 2263: 42-58 _ _ 'http://www.mapress. com/zootaxa/2009/f/zt02263p058.pdfi $\overline{2} \overline{0} \overline{1} \overline{7} / \overline{0} \overline{2} / \overline{0} \overline{9}]$.

KraAtz, G. 1860: Ueber die Gattung Diochus Er. Wiener Entomologische Monatsschrift 4: 25-28. _ _ _http://www.biodiversitylibrary.org/part/206771\#/ summaryi [accessed 2017/02/09].

PoINA - G. Ö., Jr. 1992: Life in Amber. - Stanford Univ Pr, Stanford, Calif: 368 pp. - ISBN: 978-0-8047-2001-4.
SHARP, D. 1876: Contributions to an insect fauna of the Amazon Valley : Coleoptera-Staphylinidae. Transactions of the Entomological Society of London. 24: 27-424 - DOI: $10.5962 /$ bhl.title.5536

ShaRP, D. 1882-1887: Insectà. Coleoptera. vol. 1 pt. 2. - Godman, F. D. \& Salvin, O. (eds): Biologia CentraliAmericana : zoology, botany and archaeology. - Published for the editors by R. H. Porter, London: 870 pp. - DOI: $10.5962 / \mathrm{bhl}$.title.7301 - http://www: biodiversitylibrary.org/item/14601\#page/ $/ 770$

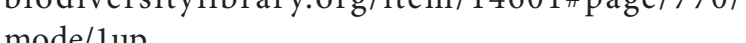
mode/lupi

SMETANA, A. 1977: Lectotype Designations and Taxonomic Remarks on Some Xantholinine Genera and Species from Central and South America (Coleoptera: Staphylinidae). - _ The _Coleopterists Bulletin _ 31(4): 347-362 - http://www.jstor.org/' istable/3999893; [accessed 2017/02/09].

SMETANA, A. 1982: Revision of the Subfamily Xantholininae of America north of Mexico (Coleoptera: Staphylinidae). - Memoirs of the Entomological Society of Canada 114(S120): 1-389 - DOI: 10.4039/, 'entm114120fv' 